\title{
THE MEROK FEAST OF THE SA'DAN TORADJA
}


H. van der Veen - 978-90-04-28673-3

Downloaded from Brill.come4/26/2023 12:55:55AM 


\title{
VERHANDELINGEI
}

VAN HET KONINKLIJK INSTITUUT VOOR

TAAL-, LAND- EN VOLKENKUNDE

\author{
DEEL 45
}

H. VAN DER VEEN

THE MEROK FEAST

OF THE SA'DAN TORADJA

'S-GRAVENHAGE-MARTINUS N IJ HOFF-1965

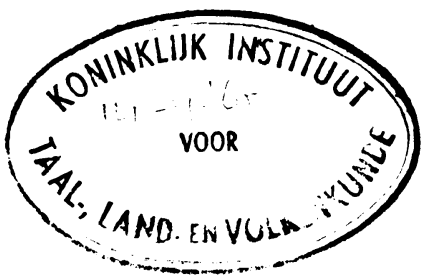


H. van der Veen - 978-90-04-28673-3

Downloaded from Brill.come4/26/2023 12:55:55AM 


\section{PREFACE}

I wish, first, to express my gratitude to the Koninklijk Instituut voor Taal-, Land- en Volkenkunde, which has kindly arranged for this book to be printed.

I am also indebted to the Gereformeerde Zendingsbond in de Nederlands Hervormde Kerk and the Nederlandsch Bijbelgenootschap for the financial aid they have given.

Furthermore I would like to thank particularly Jeune Scott-Kemball for the conscientious manner, in which she has translated this paper and the pains she has taken to translate into excellent English my Dutch rendering of the difficult language of the Texts.

The spelling used for the South Toradja text is that of present-day Bahasa Indonesia with the following exceptions: the glottal check, found in South Toradja only as a syllable- or word-final, is not written as $k$ but indicated by an apostrophe, for example, untaku' not untakuk; and the velar nasal, because it is sometimes protracted in speech and must then be duplicated in writing, is not written $n g$ but $\xi$, for example, lani' not langi'; tanz3a not tangnga.

The spelling of South Toradja words in the translation and notes differs from this system in two respects: $y$ is used instead of $j$, for example, $k a y u=k a j u$ (text) ; o-e instead of oe, for example, Lo-erara' (trans.) $=$ Loerara' (text). The hyphen is used only to make it clear that each vowel must be pronounced.

H. VAN DER VEEN

Leiden, October 1964 
H. van der Veen - 978-90-04-28673-3

Downloaded from Brill.come4/26/2023 12:55:55AM 


\section{CONTENTS}

I. DESCRIPTION OF THE FEAST . . . . . . . . . .

II. THE OFFERTORIES AND THE INVOCATION SPOKEN AT THE CONSECRATION OF THE BUFFALO . . . . . . . . . . . . . . 10 Introduction to the benedictory prayer (Text A) . . . 11 Introduction to the invocation spoken at the consecration of the buffalo (Text B) . . . . . . . . . . 11

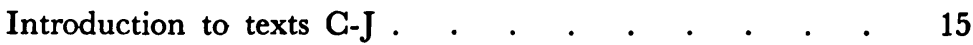

A. Mebala kollon, the benedictory prayer . . . . . 16

B. Passomba tedon, the consecration invocation . . . 18

C. Ma'pallin, the prayer at the rite for the warding off of evil forces . . . . . . . . . . . . . 156

D. Likaran bian, the prayer at the rite at which the offering meal, placed in a small basket made of the interwoven leaves of a reed, is laid down . . . . . . . . 158

E. Maßrambu lani', the prayer at the offering to cover up guilt . . . . . . . . . . . . . 164

F. Maßrimpuß, the prayer at the communal to the ancestors 166

G. Ma'bubun, the prayer when the ridge covering of flattened-out bamboo culms is laid on the roof. . .

H. Kada dipaupu', ke umpatorroi paßan susite, the concluding words spoken when the offering of sirih-pinang is laid down . . . . . . . . . . .

I. Kada dipaupu', ke umpatorroi pesur, the concluding words when the leaves with the offering meal on them are laid down.

J. Ma'tambuli, the invocation at the ma'tambuli $=$ to dig a hole in the ground with a pointed object . . . . 184

III. LIST OF SOUTH TORADJA WORDS . . . . . . . . . . 191 
H. van der Veen - 978-90-04-28673-3

Downloaded from Brill.come4/26/2023 12:55:55AM 


\section{DESCRIPTION OF THE FEAST}

The feast of which a description is presented here as it is conducted in the Kesu' territory in the Rantepao country, is called merok in the Sa'dan Toradja language. ${ }^{1}$ This word, a younger form of merauk, is a derivation of the root word rok $(r a u k) 2=$ to pierce with a lance. The feast is so called because the central part of it is the offering of a buffalo, although the offering animal is not killed with a lance but with a large chopping knife.

There are three reasons for holding this feast. First, when a man has become prosperous and has thenceforward never suffered any setback. The Toradja term for this is ke ussa'din kalena to sugi', when one considers oneself well-to-do. It is also held when a person enjoyed some years of prosperity following on the making of an atonement offering for a transgression. It is then in the nature of a thanksgiving.

Secondly, as a thank-offering after the concluding rite of the elaborate forms of the rites for the dead, i.e., the dipatallun boni, the dipaliman boni, and the dirapa'i. At the dipatallun boni, the rites are completed in three days and a minimum of three buffaloes must be slaughtered. At the dipaliman bon, the ceremonies last for five days and at least five buffaloes must be killed. The dirapa'i is the supreme form the ritual for the dead and demands a minimum of nine buffaloes. The corpse of the deceased is laid in a hollowed-out trunk of a tree for some days. There is an interval that may last for a considerable time, between the first and the second part of this last ceremony.

The concluding rite of these three forms of the rites for the dead is called manrara pare; it is performed after the harvest near one of the ricefields of the deceased. Manrara pare = to cover the rice with blood. At this rite, the person who brings the offerings to the deceased turns, in this case, to the north-east, the direction in which the offerings to the gods are made, and not to the south-west. This change of direction is termed dibalikan pesunna $=$ the offering meal placed on banana leaves is reversed for him [the deceased]. In the course of time, the merok feast is held. At the manrara pare, it is the family of the deceased who always participate, but at the merok feast that follows, all those

1 The Sa'dan Toradja are the main group of inhabitants of the South Toradja area, South Celebes, Indonesia. A description of the merauk feast held in the Sa'dan territory in the north of the Rantepao country, is to be found in: „De Boea' en eenige andere feesten der Toradja's van Rantepao en Ma'kale”, J. Kruyt, Tijdschrift Bataviaasch Genootschap van Kunsten en Wetenschappen, Vol. 60, 1921, pp. 161-167.

2 Most of the Toradja terms used in this description are to be found, under the root words from which they are derived, in the Tae' (Zuid-Toradjasch)Nederlandsch Woordenboek written by the author, published by Martinus Nijhoff, The Hague, 1940.

Verh. dl. 45 
members of the clan who are descended from the ancestor who founded the clan-house, the tonkonan, take part.

In the adat communities on the western slope of Mt. Sesean, in the Rantepao country, the maro-feast is held as the concluding rite of the rites for the dead (see below). Here also, the object is to send off the spirit of the deceased to the abode of the gods.

Thirdly, the merok feast can be celebrated by a slave or a serf who has become a freedman, by performing the ceremony known as ma'talla', or ma'tomakakai, at which he has to give a number of buffaloes and pigs as payment for his freedom. He is then regarded as a freeman, to makaka. If, in due course, he becomes prosperous, he may hold a merok feast as a thank-offering.

In all three cases, the same ritual is observed at the merok feast.

When it has been decided to celebrate the merok feast, the first of the feasts to be held is the maro feast. 3 Maro $=$ frenzied, mad. During the course of this feast some of the participants, in order to drive away sickness, go into a trance and are able to perform abnormal things. All the members of the clan-house take part in this feast. If there is a serious sickness in the adat community, then the rites performed serve to drive it away. If there is no serious sickness, then the general aim of the feast is to invoke the benediction of the gods. The following are the rites at the maro feast: an offering is made to the ancestors, dipakande to matua = a meal is given to the ancestors. The offering, a black chicken, is laid on banana leaves and put on the ground on the south-west side of the house. The to minaa $=$ the one who knows the offering ritual and the offertory, officiates. One could call him the officiating priest except that at some great offerings he is not the actual offerer, only a deputy: the adat chief is then the officiant. On the day following the offering of a meal to the ancestors, the to minaa makes an offering to the gods, umpakande deata = to give an offering meal to the gods. The offering is a fowl. The offering meal is placed on banana leaves and laid on the ground. The main feast takes place some days later. At the maro feast, only fowls can be offered and a great number of them are killed for it. They are offered to the gods. There is a direct connection between the using of fowls and the name of their progenitor, Puan Maro = Lord who is Frenzied, (see strs. 461/466 of the text on the consecration of the buffalo, B).

: For a description of the maro feast in the Balusu territory in the north-east of the Rantepao country, see J. Kruyt, Tijdschrift Bataviaasch Genootschap voor Kunsten en Wetenschappen, Vol. 60, 1921, pp. 172-180. 
When the aim of this feast is to drive alway sickness, people gather at the house of the sick person night after night. The maro song is sung and all kinds of acts are performed in order to achieve this object.

The second series of rites in the merok cycle is called mananta' = accompanying. Their technical significance in the offering ritual lies in the hanging-up of woven textiles and other ornaments on the northeast side of the small offering table to which the offering to the gods is brought.

The first rite in the series is again the bringing of an offering, a black fowl, to the ancestors, and again it is laid at the south-west side of the house. The day after this offering has been made, the actual mananta' takes place, when three pigs are offered to the gods. These pigs are first consecrated, disuru' $=$ they are purified. This word is a derivation of suru' $^{\prime}=\mathrm{a}$ comb. In this ceremony, the to minaa utters an invocation and lays a betel leaf, a small piece of areca nut and a little lime on the pigs. Then he makes the offering. For this purpose a small offering table is used on the bamboo supports of which there are incised motifs. For this reason this rite is also called massura' tallan $=$ to incise motifs on thin bamboo. The man who carries the offering and who speaks the offertory, manimbo, is not the same to minaa who consecrates the pigs.

After an interval of time, a month or even a year, the main feast is held, usually after the harvest. The first rite of the main feast of the merok ceremonies is the ma'pallin. Its aim is to dispose of magically evil forces. Here a black fowl is offered at the west side of the house. The payment for the to minaa consists of sirih-pinang, with three old coins, uay, laid on top, all placed in a small basket. The offertory which is then spoken is given in II C, with translation and notes.

The second rite is called likaran bian, the weaving together of the leaves of a variety of reed, the arrow cane (Miscanthus japonicus Andersen). Four of these stalks are stuck in the ground; their leaves are woven together to make a small basket upon which the offering meal is placed. This small offering structure is set up at the north-east side of the house. The offering at the likaran bian, is a dark-yellow fowl with brown spots on it, manuk rame. Rice, cooked in a bamboo container, dipion, from which the outer rind has been peeled, is also offered. For the offertory spoken on this occasion, see II D.

The third rite is called manrambu lani' = to veil the firmament with smoke. The general aim of this rite is to obliterate the guilt resulting from a serious transgression. This rite is also held after a serious offence if no merok feast is celebrated. If the committing of incest is the reason 
for holding the rite, then a buffalo must be slaughtered. Within the framework of the merok feast, a pig is slaughtered. The portions of this pig are stuck on three pieces of wood and are completely consumed by fire. None of the flesh of this pig may be eaten by those participating in this ceremony. The offertory is given under II E.

The fourth rite is the manrimpun = to gather together in a family group, either to make offerings to the gods or to the ancestors. In this context it has the meaning of gathering together as a family group in order to bring an offering to the communal ancestors. The offering is a pig. For the offertory, see II F.

The fifth rite is called membase kandian = to cleanse the eating utensils. The offering is a fowl. A bamboo stake is set up slanting towards the north-east and unfolded, young leaves of the sugar palm are attached to it, as well as a small basket made of plaited leaf ribs of the sugar palm. The offering meal is placed in this basket. This offering structure is called the tadoran; the proceedings are termed matadoran. This tadoran is erected at the north-east side of the house of the giver of the feast. The offertory is similar to that spoken at the manrambu lani,, see II E.

The sixth rite is the ma'bubun = to lay the ridge covering of flattenedout bamboo culms on the roof. This bamboo covering is made and a pig is then offered. When the to minaa makes the offering of sirih-pinang to the gods, he speaks the offertory given in II G. The concluding words of the prayer spoken at the offering of the sirih-pinang and at the offering of the meal is given in II H and II I, respectively.

On the day following this rite, that of the cleansing of the well, mankaro bubun, is performed. The aim of this ceremony is to purify the well in case it has been made impure, thus averting any magical effects that might bring misfortune. The offering is a fowl.

The rite that follows is called massali alan = to lay a floor beneath the rice granary. This floor is sited in the lower part of the rice granary and the drums which will be struck on the great day of the feast, are placed upon it.

The day after this ceremony, a rite is performed which is called untammui lalan tedon $=$ to go to meet the way of the buffalo. The aim of this rite is to prevent anything inauspicious happening during the time that the buffalo which is to be slaughtered, is on its journey. The offering is a fowl. The offering meal is placed behind the house.

On the same day, the rite called $m a^{\prime} p a s o m b a^{\prime}$ bale $=$ to transfer a school of fish, is performed. A fowl is offered at the ricefield. At the 
opening in the dyke of the ricefield through which the water flows, a small channel is constructed to entice the fish, primarily shrimps. This rite is also called manalli bale = to buy fish. Its aim is to obtain the quantity of fish needed for the following feast days.

Another ceremony performed on this day is the manrara kombon $=$ to cover the sugar palm plantation belonging to the clan-house with blood. The participants go to a small group of sugar palm trees and there they offer a fowl. Another name for this rite is manalli tuak = to buy palm wine. Its aim is to obtain a sufficient quantity of palm wine for the coming feast days. On the same day, the rite called lanzyan $K e s u^{\prime}=$ to ascend to the region of the Kesu' rock complex, is also performed. Those taking part go to a high part of the mountain and there offer a cock with dark brown feathers and white legs.

The next day, the rite called $m a^{\prime}$ pasa' = to go to market, is held. For this the women adorn themselves with a headband, $s a^{\prime} p i$, decorated with gold leaf, parakeets' feathers and human hair, and put on their festival clothing. They take with them palm wine and viscous rice wrapped in a leaf of the bamboo called pattun (Bahasa Indonesia: bětun) (Dendrocalamus flagellifer), and offer them to such of the clan members as they find in the market place. After that, arrangements are made regarding the commencement of the ritual of striking the drums, ma'patama ganday.

On the day following, the rite is performed which is called $m a^{\prime}$ pasan tedon $=$ the gathering together of the buffaloes at an appointed place. The buffaloes belonging to the members of the clan are brought to a specific place outside the village of the clan-house. A pig is offered there. The foreheads of the buffaloes are smeared with the blood of this pig. Viscous rice, rice cooked in milk and pig fat, tina'nak, is put before the buffaloes.

Next day an offering is made to the ancestors, ma'pakande to matua $=$ to offer a meal to the ancestors. On this day the striking of the drums is included in the ritual, ma'patama ganday = to bring the drums within, i.e., within the ritual. The drums used on this occasion are those exclusive to the rites where offerings are made to the gods. They are distinct from the drums that are struck during the rites for the dead. Neither may be used indiscriminately because, to the South Toradja, everything that concerns adat usages which are directed to the gods, rambu tuka'= smoke which ascends on high, is rigidly distinguished from everything that relates to the rites for the dead and to the worship of the ancestors, rambu solo' $=$ smoke which descends. 
At the ceremony for the including of the drums, a fowl and a pig are offered. The offering meal is placed on the drums in the clan-house. The drums are then struck for the first time, and, with intervals, they are struck continually throughout the following two days.

On the second of these two days, the rite called ma'kollon gandan = the drums receive a ring of flesh from the neck, is held; the offering is a pig. Two rings of flesh are cut from its neck and a ring is then placed on each of the drums.

On the third day, the drums are taken to the rice granary, ma'popenkalao gandan $=$ to take the drums below. At this ceremony a chicken is offered. The drums must always be struck, without cessation, while they are being transported, and also while they are being taken back to their place in the house. Should that not be done, then those who are carrying them would become deaf. This is the day on which the rite called tallu basonna $=$ the three twisted ropes, takes place. On this day, everything that is required for the great feast day is put in order. Those concerned go to a tjendana tree where they scatter roasted unhusked grains of rice. They then cut a strong branch from the tree, and place on the ground a bamboo container in which there is cooked rice, pion.

A long, narrow, blue woven cloth with white motifs on it, sarita, is attached to the tjendana branch which is then stuck in the ground at the north-east side of the clan-house where the feast is to take place. A liana and a length of rattan are also fixed to this small tjendana tree. The other ends of the liana and the piece of rattan and of the blue cloth are attached to a petuo pole of the clan-house. There are three, sometimes four, of these petuo = bearers of life, in a clan-house. They are affixed to the petuo which is on the north side of the central apartment. These petuo are erected on the longitudinal beam which extends beneath the floor of the house and support the ridge beam of the house. Offerings are placed at the petuo when a newly-built house is consecrated, and when the roof covering of an old house is renewed.

On the same day, and on the following day, the front of the clanhouse is decorated with pieces of beadwork, kandaure, and woven cloths. In the evening of the first day, the buffalo which is to be consecrated and offered, is tied up to the small tjendana tree. Also on the same evening, or on the evening of the following day, the rite called $m a^{\prime} t a m b u l i=$ to dig a hole in the ground with a pointed object, takes place. The adat chief, or usually the to minaa who deputises for him, makes a hole in the ground with a small shovel, pesese, and utters a 
benedictory prayer (see II J). The adat chief, or the to minaa, is clothed in a long white sleeved gown, bayu lamba', an old short wide woven cloth, called a maa', is wound round his head, and he wears a chain of gold beads round his neck. A litter, with a pig on it, is placed on the western side of the buffalo. Three female members of the family of the giver of the feast, who are chosen by ballot, sit at the place where the feast is to be held. Each has a winnowing basket of husked rice in her lap and they continually throw the rice from one basket to the other.

When the ma'tambuli has been performed, the buffalo is consecrated, massomba tedon. The root word, somba (in Malay and Javanese, sémbah) means to worship, to adore, to make homage to. The invocation which consecrates the buffalo is spoken by another adat chief who comes from a clan house that has a definite link with the clan house of the giver of the feast. Here again, the to minaa can deputise for this adat chief. The officiant is dressed in the same way as the adat chief, or the to minaa, who performs the ma'tambuli rite. In his right hand he holds a lance which he moves to and fro. At his left stands another adat chief who, in some adat communities, is called the to indo', or indo' paday = leader of the rice cultivation. This second adat chief, or the to indo', holds a yellow-brown cock, or a dark-brown cock with white legs, on the palm of his hand while the consecration invocation is spoken. For this reason, he is called to manrande london $=$ he who holds the cock on his open hand. The mouth of the buffalo is tied up during the speaking of the invocation, so that it cannot make any sound while the ceremony is in progress.

The consecration invocation begins at about 11 p.m. and continues throughout the night until the first streaks of dawn. The text of the invocation is given in II $B$.

The three offering animals, the cock, the pig, and the buffalo are slaughtered after daybreak. This is the great day of the feast, allonamo kaperaukan, the day of the merok feast: it is also called matanna kaperaukan = the main constituent, the essential part of the merok feast. The buffalo is made to lie down when it is to be slaughtered. It is not, in fact, pierced with a lance; a large chopping knife is used and the animal is struck through its heart. A betel leaf, and a piece of areca nut, are placed on the spot where the buffalo is to be killed, and a little lime is also strewed there. The first blood to flow from the wound when the buffalo is killed is taken away by the men who usually tap the sugar palm to get the palm wine. The object of their taking the first 
blood, is to ensure that the juice in the sugar palms will flow abundantly when they tap them. The blood that later flows from the wound, is caught in a bamboo container. It is then poured into a porcelain dish and mixed with the blood of the cock and the pig. The foreheads, the cheeks or the palms of the hands of those participating in the feast, are lightly dabbed with this mixed blood.

After the buffalo has been consecrated, the drums, over which an old woven cloth has been laid, are with intervals, struck continually.

A large red cotton cloth is hung round the place where the offering is to be made, the to' panantaran = the place where the woven cloth is hung. Slats of bamboo are laid on stakes and old woven cloths and beadwork are hung on them. Beside this structure a small offering table is erected on four bamboo struts on which motifs are incised. A small platform is constructed in the middle of these struts.

The top of each of these struts is hollow, forming a container; palm wine is poured into three of them and water into the fourth. An old woven cloth is hung round the small offering table. Ribs of the leaf of the sugar palm are attached to the tops of these four struts. The outsides of the leaf ribs are scraped and kapok, smeared with the blood of the offering animals, is wrapped round them at various places. These ribs, wrapped in the blood-smeared kapok are called pandun balo. A passakke plant, a plant which has red flowers and small fruit, and which is used at various offerings to bring coolness i.e. blessings, is tied to the four struts of the small offering table. The word sakke= cool, and masakke = blessed. In front of the offerer is a plate on which there is a small piece of iron from a roasting dish, pamuntu, and three yellow beads. The offerer is called the to ma'pesun $=$ the one who sets down; pesun is derived from paisun, a pa-form of isun = to set down. The place of the offering is strewn with roasted, unhusked rice grains.

The offerer has hold of one of a number of pelole', young leaves of the sugar palm, which are hung on the bamboo stake of the tadoran (see p. 4). In his right hand he holds first a small bamboo container with water in it and later a small bamboo container with palm wine in it. Before the offering meal is placed on the banana leaves, for which purpose the right half of the whole leaf is used, sirih-pinang is offered to the gods: a betel leaf, a small piece of areca nut and a little tobacco, over which lime is sprinkled. Gambir (catechu) is a more recent importation and is not offered to the gods. After the offering of the sirih-pinang, the offering meal of meat and rice is placed on the banana leaves. Two of these banana leaves with the offering meal on them, are 
placed in the small basket on the tadoran. A small offering table is erected beside the tadoran. This table, supported on four bamboo struts with motifs incised on them, is called surasan tallan= structure of bamboo on which motifs are incised. A small platform is constructed in the middle of these struts (see p. 3).

Two banana leaves with the offering meal on them are then placed on this platform. The offering meal consists of parts of the lungs. kidneys, liver, brisket and the fat of the buffalo and the pig, as well as the ring of flesh from the pig's neck, and yellow viscous rice. No part of the cock is used in this offering.

The bearer of the offering is the principal adat chief in the adat community in the Kesu' territory; he is called sokkon bayu = the neck of the jacket. The adat chief next in rank to him is the chief who consecrates the buffalo, to ussomba tedon. The to minaa can deputise for these two adat chiefs. Of the other adat chiefs: one performs at the offering as the to manobok= the one who stabs the offering animal, another acts as the to massadi= the one who cuts the flesh in pieces, and yet another as the to ma'nasu= the one who cooks. The sixth adat chief is the to massanduk = the one who ladles out the offering meal. After the sirih-pinang has been offered to the gods, the offerer calls upon the gods to wash their hands. For this purpose he holds in his right hand a small container with water in it. Next he takes in his right hand a small container with palm wine in it and invites the gods to partake of the offering meal.

The idea is that the gods take unto themselves the essence of the offering gifts. The offering meal, of which the essence is partaken of by the gods, is called tampak pesun, the final part of the offering meal. After the offering prayer has been spoken, the members of the clanhouse can take up the offering gifts and dispose of them. They bring blessings. People then go and sit in small groups and eat together.

In the evening, the young girls and the young women, dressed in their festival clothes and adorned with ornaments, place themselves in a row and start singing a humming song, ma'dandan = to stand in a row.

The following day, a small tjendana tree is planted at the north-east side of the rice granary in the forecourt of the clan-house. The to minaa offers a fowl. Another fowl is offered on this day and its blood is smeared on the sides of the drums which are struck during the feast. The drums are then returned to their places, being struck continuously while they are being taken back. 


\section{THE OFFERTORIES AND THE INVOCATION SPOKEN AT THE CONSECRATION OF THE BUFFALO}

The invocation spoken at the consecration of the buffalo, as well as the various prayers and the invocation given at the ma'tambuli, consists of a number of homonymous strophes. These prayers and the matambuli invocation precede the consecration invocation, but because the last mentioned is the pièce de résistance, preference will be given to it here.

The texts are thus in the following order:

A. Mebala kollon: the benedictory prayer.

B. Passomba tedoy: the consecration invocation for the buffalo.

C. Ma'pallin: the prayer at the rite for the warding off of evil forces.

D. Likaran bian: the prayer at the rite at which the offering meal, placed in a small basket made of the interwoven leaves of a reed, is laid down.

E. Maßrambu lani': the prayer at the offering to cover up guilt.

F. Manrimpun: the prayer at the communal offering to the ancestors.

G. Ma'bubun: the prayer when the ridge covering of flattened-out bamboo culms is laid on the roof.

H. Concluding words at the ma'bubun when the offering of the sirihpinang is laid down.

I. Concluding words at the ma'bubun when the leaves with the offering meal on them are laid down.

$\mathrm{J}$. The invocation at the ma'tambuli= to dig a hole in the ground with a pointed object. This invocation immediately precedes that of the consecration of the buffalo. 


\section{Introduction to the benedictory prayer}

(Text A)

This prayer, like the consecration invocation for the buffalo, was taken down by my former language assistant, Mr. J. Tammu, direct from the to minaa, the expert on the adat rules and offering prayers, who was usually the bearer of the offerings to the gods and to the ancestors. His name is So' Sere and he is from the village of Anin-anin in the Kesu' territory in the Rantepao country.

The words are recited in a slow, calm manner; the concluding words of each strophe are delivered at a slightly faster tempo.

Before the consecration invocation for the buffalo is begun, the adat chief, or the to minaa deputising for him, first calls for a blessing upon all who are to participate at the feast and for all the ceremonies to be performed. This is called mebala kollon $=$ (literally) to enclose the neck. Figuratively, it means to protect oneself against calamity and death, against the wrath of the deceased and of the living, especially when a ceremony is performed that follows adat procedure or when words are spoken that relate to it; in general, to invoke blessings when weighty matters are discussed.

The person who utters the blessing affirms that he is assured by the concensus of opinion of the participants at the feast, in particular the adat chiefs, that the whole clan supports him and that nothing should disturb the progress of the consecration invocation or hinder the performance of the great offering.

\section{Introduction to the invocation spoken at the consecration of the buffalo}

(Text B)

In this invocation there is narrated how the world of the gods came into being, how mankind was created, and the details are given of the prototype of the ritual, with the various offerings, as it was performed in the firmament; those who had to perform the offerings, the slaves who had to assist, and the offering animals that were required are named.

Three children were born of the union of heaven and earth:

Poß Tulakpadaß, Poß Baßgairante and Gauntikembon.

They created the sun, the moon, and the stars.

Pon Tulakpadan is the Lord of the world under the earth.

Pon Bangairante is the Lord of this world, the middle world.

Gauntikembon is the Lord of the upper world. 
The earth is a flat plain. Above it is the firmament, curved into twelve arches. Below it, similarly twelve-arched, is the lower world.

Gauntikembon betook himself to the centre of the firmament. From his floating rib he fashioned a divine being called Usuk Saßbamban. He made his way to the East and, after he had made the cleansing offering, united in marriage with a woman called Simbolon Manik who had come forth out of a rock. These two personages appear many times in the genealogy of the gods.

From this union of Usuk Saybambay and Simbolon Manik, was born Puan Matua. He also made the cleansing offering and then united in marriage with a woman called Arran Dibatu. She, too, had come forth from a rock. No children were born of this union. Puan Matua then went to the West in order to obtain the pure gold.1 Having found it, he put it in a cooking pot. He then set beside it a pair of bellows of equal size in which unhusked rice was strewn. From this pair of bellows there came forth 8 mythical beings, ${ }^{2}$ among them being the heavenly ancestress of man, Datu Laukku'.

Puan Matua is the most prominent figure in the pantheon of the South Toradja. Later in the course of the invocation, he is defined as the one who directed the procedure.

After the help of the divine ancestors has been invoked, in order to put right any error that may have occurred during the request for blessing on every constituent of the offering feast, the prayer is addressed to Puan Matua for his assistance (str. 42). He is then invoked in an extensive hymn of praise as the god in the centre of the firmament, as the god who balanced the period of the night and the day against each other, as the god who spread out the broad plain, who formed the wet ricefields, who fashioned the sun as a disc, who cut out the moon as a circle, and who created mankind (strs. 46, 49, 50, 51, 54, 55 etc.).

Then Puan Matua, as the first god in the row of gods, is begged to summon his co-gods to proceed to the offering place (strs. 96, 97).

The gods in the firmament are summoned: the eight gods on the westward path of the sun, the eight in the south, the eight in the east and the eight in the north (str. 89/92).

The God of the Underworld, Pon Tulakpadan, who resides in the clefts below the earth, is invited to accompany the row of gods who are setting out, and the eight gods in the west of the lower world, the

1 Gold is found in the westerly territories of the Ma'kale and Rantepao regions (the present-day Tana Toradja).

2 Poß Baygairante also begat eight mythical beings when he married. 
eight gods of the south, of the east and the north are also invited (strs. 141, 172/175).

The gods of this world are then invoked: the gods of the open fields, the gods with whom we sit down together, whose wells we bail out (strs. 202/205).

The various local gods who are the deified forefathers and who dwell on the mountains and reside in the different regions are invited. The first of these gods to be invoked is the God of the Kesu', a limestone rock to the east of the principal town, Rantepao, and upon which the ancestor of the most prominent lineages of the Kesu' territory, Puan riKesu', descended from heaven. He is requested to summon his co-gods. This consecration invocation originated in the Kesu' territory, hence Puan riKesu' is the first god in the row. A great row of deified forefathers from the whole Sa'dan Toradja country and from the neighbouring regions of the Luzeu' and the Duri country are then summoned. All these gods are requested to bring with them the pusaka objects belonging to their regions (strs. 292/299).

When Puan Matua is invoked, the names of Puan Bassi-bassian and Puan Ambo-amboan are often added. Sometimes the combination of these names is interpreted as a trio indicating the same godly figure. The name of Puan Bassi-bassian = The Lord Covered with the Spots of Old Age, and Puan Ambo-amboan = The Lord Whose Skin is Marked with Light Spots, are then regarded as epithets of Puan Matua. These two names are sometimes given to individual gods, as in strophe 732, where it is told how Indo' Belo Tumban who brought the medicine to be spat on the sick, to Puan Matua sat down and chewed betel with Puan Matua, Puan Bassi-bassian and Puan Ambo-amboan.

In the genealogy of the gods, Gauntikembon, from whose floating rib sprang the father of Puan Matua, is said to have the alternative name of Puan Ambo-amboan, and Usuk Sambamban, the father of Puan Matua, the name of Puan Bassi-bassian.

Puan Matua means "The Old Lord", or "The Old God". Both this name and his alternative name, To Kaubanan, "The One Who Has Grey Hair", as well as the names Puan Bassi-bassian and Puan Amboamboan point to a god, or gods, who existed in olden times. 3

3 In Australia the Supreme Being is also represented as an old grey-haired man. See Professor Dr. H. T. v. Baaren's $W_{i j}$ mensen, published by Erven J. Bijleveld, Utrecht, 1960, p. 62. Mythical beings are almost always represented as old men by the Papuans of Waropen, see Professor Dr. G. J. Held, Papoea's van Waropen, published by E. J. Brill, Leiden, 1947, p. 62. 
In this invocation a picture is given of the prototype of the offering ritual as it was originally performed in heaven, in its simplest form, to the elaborate sequence of rites of the bua' feast. In the cycle of offerings made by the $S a^{\prime} d a n$ Toradja, there is a step by step graduation of a ritual that had its origin in a particular need.

In its simplest form the ritual consists of the offering of rice and a fowl placed in a small offering basket made of the interwoven leaves of four reed stalks; this is called ma'lika' bian. At the offering that follows, a pig is offered on a small offering table erected on bamboo struts; this offering is called massura' tallan. The maro feast is held after that. This serves to drive away sickness and to promote the welfare of the adat community. The merok feast then follows, and, as the culmination of the cycle, the great bua' or $l a^{\prime} p a^{\prime}$ feast can be celebrated if the situation in the adat community is auspicious.

The invocation mentions first of all an expiatory or cleansing offering in the firmament at which a bamboo container full of millet was offered. At that time the progenitor of rice had not yet come into being (str. 440).

Before the four struts of the first house in the firmament were erected, an offering had first to be made at which a fowl was offered in the small offering basket made of the interwoven leaves of four reed stalks (strs. 543/547). When the house was being built, a pig had to be offered. This pig came forth from a basalt rock and the offering was made forthwith and the offering meal was laid on a small bamboo table.

A ricefield was laid out in the firmament (str. 591) but the harvest was not as it should have been. Then two youths sprang from the pair of bellows belonging together. They were the ancestors of the leaders of rice cultivation, indo' padan. They watched over the observing of the prohibitions in respect of the rice and thereafter the ricefield produced an abundant harvest. The merok feast, for which a buffalo had to be slaughtered, could then be held.

The invocation then mentions the various adat performances at which a fowl must be offered and states the requisite colour of the fowl's feathers in each case. It also speaks of the special offerings at which a buffalo must be offered and notes the special kind of horns it must have (strs. 636/643) and 653/673) respectively. The buffalo for the merok feast is well-formed and has yellow skin.

The ancestor of the to minaa = those who know the invocation, spoke it with his face turned towards the buffalo (strs. 670/673).

Sickness appears in the centre of the firmament; Indo' Belo Tumbay, 
who had the medicine to be spat upon the sick, is invoked. She has under her protection those who are treated at the maro feast for driving away sickness. The holding of the maro feast is then mentioned (strs. 726/751).

Finally, there is a description of the great $b u a^{\prime}$ or $l a^{\prime} p a^{\prime}$ feast (strs. $752 / 771) .4$

\section{Introduction to texts C-J}

'The communicant of Texts C-J inclusive, was So' Sere, a to minaa of the village of Anin-anin, Kesu' territory, in the Rantepao country. It was written down by my language-assistant, Mr. L. Pakan.

4 See J. Kruyt: „De Boea' en eenige andere feesten der Toradja's van Rantepao en Ma'kale", Tijdschrift Batavinasch Genootschap van Kunsten en Wetenschappen, Vol. 60, 1921/22, pp. 45 and 161. 


\section{A. MEBALA KOLLON}

1 Bendanmo' te petoe soßkaß sikaßkan doke diremak.

Tumannanmo' te pedeken panaaran sitoe induk disila bannaß.

2 Apa baßunpa' la mekutana london lako te to ma'rapu tallaß.

Dioßpa' aku la metinti masian lako te to ma'kaponan ao',

3 kumua: Sundunraka mitoean kada, rapa' midemme' batu eranku?

Upu'raka mitoean tenko situru', mikala'pai tampak pelalanku?

4 Apa ma'kada te ma'rapu tallaß,

kumua: Mankamo kitoean kada ra'pa'

sola to ditanan indo',

to diranduk paßlaa padaß.

5 Maßka dukamo kitoean teßzo situru'

sola torkonan bara'

na esuran sanda kalando,

kikala'pai tampak pelalanmu.

6 Melomo te kutirandukki usserek bannaß nene' mendeatanna titanan tallu.

Maballomo te kutirandukki la umbille pantasi to dolo kapuananna samba' batu lalikan.

1 induk disila bannan = sugar palm cleft along the prescribed line; it is the poetical parallel of the word lance.

2 mekutana london = "calling as does the cock": the idea here is that the cock's continual nodding of his head looks as though he is calling the hens.

"I stand here below", i.e., below in the forecourt in front of the clan-house. metinti masian = constantly to give a clear call; the parallel expressions are: mekutinti saunan = always making a sound like a fighting cock, and mekutitti bayan $=$ repeatedly to make a noise like a parakeet.

$3 r a p a^{\prime}=$ silent, satisfied, reconciled.

"my stair", i.e., the step of the house of the person who is speaking the invocation.

"the stone of my stair", i.e., the stone that lies at the foot of the stairs.

tenko situru' = the plough that goes in one and the same direction; figuratively, agreement.

4 to ditanan indo' $=$ those who are planted as mothers; indo', in connection with a word such as region has the meaning of leader, to indo' and indo' padan mean the leader of rice cultivation and of the offerings connected with it; indo' bua' $=$ chief of the adat community; to ditanan indo' has the same meaning as pekaindoran $=$ he who is regarded as the mother of the adat community, the adat chief.

diranduk $=$ they were pricked into the ground; i.e., with a sharp object.

5 tonkonan $=$ the place where one is seated. Bara' (Mal. barat $)=$ great, powerful; to bara' $^{\prime}=$ powerful adat chief; tonkonan bara': clan-house which holds the most prominent position in the adat community.

6 usserek bannay = to draw apart one by one; i.e., like the threads of yarn. nene' mendeat $a=$ the forefathers who have the essence, the quality, of gods. 


\section{A. THE BENEDICTORY PRAYER}

1. "Here I stand, I who hold the small bamboo container, who hold in my hand the lance on which the areca nut is stuck.

"Here have I placed myself, I who grasp the small container, I who hold in my hand the sugar palm, cleft along the prescribed line.

2. "For I stand here now in order to ask you, calling as does the cock, the clan members here, numerous as bamboo culms growing together on the same stool,

"I stand here below, to ask continually and to be clearly informed by the ones whose group always increases like a bamboo stool.

3. "I ask you: 'Have you brought the mutual discussion to an end, so that you may finally press your hands on the stone of my stairs?

'Have you already reached agreement, that you may hold the end of my ladder?" "

4. The clan members, numerous as bamboo culms growing together on the same stool, reply:

"We have already come to a decision in our discussions with the ones who are placed as guardians,

with the ones who are set up as protectors of the land.

5. "We have also reached agreement

with the mighty clan-house

and the supreme seat, and so we hold the end of your ladder."

6. "Now that agreement has been reached, I commence the mentioning, one by one, of the divine progenitors of the ones that form a trinity. Now that it is auspicious, I shall start to name separately each of the progenitors, revered as gods, of the ones that belong together, like the three stones of the hearth."

titanan tall $u=$ to be set (planted) as a trinity; i.e., a trinity belonging together $=$ the buffalo, the pig, and the cock which are killed on the great day of the feast and of which the blood is mixed.

"that belonging together like the three stones of the hearth"; i.e., the buffalo, the pig and the cock.

umbille pantasi $=$ to separate one by one the threads that have been soaked in rice water; the pantasi is the thread that is soaked in rice water before weaving begins, in order to stiffen it.

Verh. dl. 45 


\section{B. PASSOMBA TEDON}

1 Kurre!! kurre!! kurre!!!

Kurre sumaßa'na te padaß tuo balo',

2 maßkamo nasampa' rara' nene' mendeatanna te to ma'rapu tallan nabaßunni banua.

3 Saba' parajanna te tana tumbo kulau', napata bulaan to dolo kapuazanna te to ma'kaponan ao' umpate'dani a'riri sanda pati'na.

4 Kurre sumaßa'na te takinan pia, saba' parajanna te selleran loton ulu.

5 Kurre sumaßa'na te uaß mabilazan, saba' parajanna te pa'kombon to Balanda.

6 Kurre sumaza'na te banua dilindo puaß, nanii bendan boßana gau'. saba' parajanna te sondon dirupa deata, la nanii tunannan samiara bisara.

1 kurre: this word is used to call the chickens; in this context it is the call with which the vital force is summoned.

sumaß̧a' (Mal. sermanat) is a variant of suza' = vital force, length of life; sumana' also means vital force, but it is nearer the meaning of consciousness, spirit, soul. The words kurre sumana' are used when the word 'Hail' is called out to a person's vital force.

2 rara' $=$ neck chain; worn by women; see 110.

sampa': to recall in a ballad something that happened previously.

3 puaß = God, Deity, Lord. It is also the title of members of the princely families who are of pure blood; their ancestors were heavenly beings who descended to earth; kapuazan = having the status of a god or lord; it also means bearing the title of puan, and see 293, 338.

4 untakin = to bind something to the waist; for example, a sword.

selle': to stick something between the waist and the clothing; also to carry regularly with one.

loton $u l u=$ the black-haired one; this is the poetical expression for mankind.

5 "old money" = uan: the Dutch East India Company's coinage. This money is also called in the poetical language, panampa to Bone = that which is made by the people of Bone.

According to tradition, they made it. They introduced it into the Toradja country. The parallel expression to panampa to Bone is pantari' to Balanda= that which is made round by the Dutch. In former times, the people of Bone and the Dutch were types of people who were strange to the Toradja. In the 


\section{B. THE CONSECRATION INVOCATION}

1 Hail! Hail! Hail!

Hail to this soil, rich with blessings.

2 Extolled exultantly as bearing good fortune, by the divine ancestors of the ones who are the descendants of the clan-house, numerous as bamboo culms, who built the house.

3 Abundant be the blessing upon this prosperity-bringing soil, glorified with golden words by the forefathers, revered as lords by those present, whose group always increases like a bamboo stool, who have erected the support poles cut to the correct size.

4 Hail to the carrying of offspring on the hip, abundant be the blessing upon the bearing of a human being at the waist.

5 Hail to the vast quantity of old money, abundant be the blessing upon these things made by the Dutch.

6 Hail to this house, with its front shaped like the faces of the gods, where the supreme feast is to take place, abundant be the blessing upon this facade, formed like the countenances of the lords, where the foremost adat performances are to be carried out.

poetical language they are still used as parallels, for example, in the maro song: "having a stalwart appearance like the people of Bone, robust like the Dutch", and in the ma'tambuli invocation: "that which is made by the people of Bone smells the agreeable perfume of it", "that which is minted by the Dutch receives its wafted sweet-smelling fragrance".

6 dilindo puan: the front of the house; it is also called $b a^{3} b a$ deat $a=$ the door of the gods. The houses are erected with their fronts facing the north. The gods dwell in the north-east and enter the house at the front. Those people who stand in a particular relationship to the gods, such as the burake, the priestesses at the great $b u a^{\prime}$ feast, and the members of the families of the puan, are carried out through the opened front of the house when they are dead.

sondon para: the three-cornered central upper part of the front and back walls of a house, sloping slightly outward at its topmost point and upon which the underneath part of the roof rests.

bona: having white patches on the head; buffaloes with such patches have an especial worth. In the poetical language bon $a=$ of great value, eminent, excellent. titanan tallu $=$ to be set (planted) as a trinity.

gau' $=$ acts, procedure, offering procedure, rite: $\mathrm{cp}$. the change of meaning of the Malay word kerrdja: bonana gau' means the most splendid of the feasts, i.e., the merok feast.

bisara (from the Buginese bitjara) = word, reason, rite, adat performance; see 13. samara: completely black buffalo with a white patch on its head and a tail with a white tip. 
7 Kurre sumaza'na te sarita to lamban, saba' parajanna te maa' to unnoroß.

8 Kurre sumana'na te gajaß ditarapani, saba' parajanna te kandaure salombe'.

9 Kurre sumaza'na te tonapa londonna, saba' parajanna te indo' simaßkoro.

10 Dipandan bara' dao banua unnarranni saziananna, dipamamma' doti laßi' dao tananan samba' ußkorok saßpa'duananna.

11 Kurre sumaza'na te dedekan gandaß, saba' parajanna te rembanan karonian.

12 Kurre sumana'na te sella' mabusa baba'na, saba' parajanna te sa'paß mapute lette'na.

13 Kurre sumaßa'na te bai ma'bulu aluk, saba' parajanna te bonde' massongo bisara.

14 Kurre sumaßa'na te tedon ma'bulu aluk, saba' parajanna te karambau massongo bisara.

15 Kurre sumaza'na te sendana sugi', saba' parajanna te kaju mentaßke ianan.

7 In this strophe and those following, the blessing is invoked over the woven cloths and other ornaments that have been placed at the front of the clan house where the feast is to be held.

8 kandaure = piece of beadwork; when it is worn by the women at the feasts it hangs from the shoulders to below the waist, narrowing towards the end, and see 76.

tarapan $=$ sarapan $=$ large gold kris.

9 te tonapa londonna $=$ this sword, its maleness; tonapa is the name of a short sword shaped like a large chopping knife.

te Indo' Simankoro = this Mother Klewang; a simankoro is a klewang shaped like a large chopping knife.

10 unnarranni=brooding over; in the sense of guarding.

doti is the name used in the Mamasa country for a spotted buffalo. In the Ma'kale country, bai doti = spotted pig. Doti lani' is the name of the cross motif in wood carving. Maa': old woven cotton tjindai cloth; it was introduced by the Dutch East India Company; when it has the cross motif on it, it is called a doti lani' $=$ the dots of the firmament.

tananan samba': the erected poles; the poetical designation for the house. unkorok $=$ to cackle, to crow.

$p a^{\prime}$ duanan $=$ that which is one of two associated objects. 
7 Hail to this old long narrow blue woven cloth, with the design of men fording a river, abundant be the blessing upon this old short wide fabric, with the pattern of swimming men.

8 Hail to this gold kris of great size, abundant be the blessing upon the piece of beadwork, with the cords hanging low.

9 Hail to this sword, excelling in magical power, abundant be the blessing upon this remarkable klewang.

10 They are stretched out full length, like the beams of the house, watching over all the property therein, splendid as an old short wide woven cloth with a cross motif on it, they are laid on the erected poles, summoning all the possessions, to protect them.

11 Hail to the striking of the percussion instruments, abundant be the blessing upon the hitting of the drums.

12 Hail tot this brown cock, with white on the tip of its ear lobe, abundant be the blessing upon this light-brown male fowl, with white legs.

13 Hail to this pig, with bristles befitting the offering rites, abundant be the blessing upon this swine, with neck hair suitable for the adat performances.

14 Hail to this buffalo, with skin befitting the offering rites, abundant be the blessing upon this kerbau, with neck hair suitable for the adat performances.

15 Hail tot this richly laden tjendana tree, abundant be the blessing upon this tree, whose branches are full of precious things.

13 aluk = religious prescriptions, offering ritual.

bisara: in strophe 6 it is the parallel of $\mathrm{gau}^{\prime}$; in this strophe it is the parallel of aluk.

bonde' $=$ large testicles.

14 karambau: in the poetical language it is the parallel of tedon $=$ buffalo.

15 sendana sugi' = rich tjendana. This tjendana, usually called sendana bona, white spotted tjendana, has a reddish heartwood and is planted when the great offering ceremonies to the gods are performed, the merok feast and the great $b u a^{\prime}$ feast. A sendana bona was planted when the alliance was concluded with Bone during the time of Arum Palakka, see strophe 659. Another kind of tjendana, called sendana donka, with a heartwood which is greener in colour, is used when offerings are made to the ancestors: donka is a tuber with large leaves (Colocassia antiquorum); it is not eaten by human beings, but is used as pig food. 
16 Kurre sumaza'na te bambalu todin, saba' parajanna te tualle lando samara.

17 Kurre sumaßa'na te tallu basozna, saba' parajanna te ue tallu lolona.

18 Kurre sumaza'na te ma'bala tedoß, saba' parajanna te ma'paßkuß karambau.

19 Kurre sumaza'na te bai makianakan, saba' parajanna te doko umpatale' anak.

20 Kurre sumana'na bujanna manuk, saba' parajanna kanuku diarru'.

21 Kurre sumaßa'na kaunan matutu, saba' parajanna ruranan papatu inaa.

22 Kurre sumaßa'na tallu bulinna, saba' parajanna tallu eterna.

23 Kurre sumaßa'na uma ma'kambuno lumu', saba' parajanna panompok doke-dokean.

24 Kurre sumana'na kalimbuaß boba, saba' parajanna to' mata uai.

25 Kurre sumaza'na kalo' titanan tallu, saba' parajanna palempan tallu ulunna.

26 Kurre sumaza'na te tallaß ma'lampa rara', saba' parajanna te ao' ma'buku bulaan.

27 Kurre suamaza'na te serekan bane', saba' parajanna te daun sumomba matallo.

28 Kurre sumaza'na te alaß dibando rara', saba' parajanna te landa' siajoka.

17 te tallu basonna $=$ that which is twisted into three ropes.

19 umpatale' $=$ to distribute, to take from one place and put in different places.

20 kanuku diarru': the claws that are trimmed with a small knife; i.e..., of the fowls; this is a poetical description of them.

21 ruranan: a person, or a family, boarded in the house of another; here it refers to the slave, or the family of the slave, living-in in the house of a master.

22 tallu bulinna: that which has three ears; and tallu ctenna: that which has three branches; are parallel expressions and are the poetical designations for rice.

23 ma'kambuno lumu' = having duckweed as a sunshade. The water-filled ricefields, whose soil is fertile, are described as having sunshades of duckweed; and see 480 .

$24 b o b a=$ large, stalwart, robust.

25 palempan: the conduit through which the water leaves the ricefield. 
16 Hail to this thick liana, with streaks on it, abundant be the blessing upon this climbing plant, with the long white stains.

17 Hail to this rattan, made into three strands, abundant be the blessing upon this plant, which is twisted into three ropes.

18 Hail to the stalling of the buffaloes, abundant be the blessing upon the stabling of these kerbau.

19 Hail to these sows, which farrow plentifully, abundant be the blessing upon these swine, that drop young, which roam far and wide.

20 Hail to these perches on which the fowls sit, abundant be the blessing upon the ones whose claws are trimmed with a small knife.

21 Hail to the dutiful slaves, abundant be the blessing upon the obedient members of the house.

22 Hail to the three-eared, abundant be the blessing upon the three-branched.

23 Hail to the wet ricefield, with duckweed as a sunshade, abundant be the blessing upon the sawahs, full of water plants.

24 Hail to the unfailing well, abundant be the blessing upon the welling-up spring.

25 Hail to the channels in the fields, springing from three sources, abundant be the blessing upon the drains, leaving from three points.

26 Hail to this thin bamboo, with the glorious internodes, abundant be the blessing upon this thick bamboo, with the golden nodes.

27 Hail to the tearing-off of the banana leaves, abundant be the blessing upon these leaves, that point respectfully to the East.

28 Hail to these rice granaries, the ends of their side and front beams curving splendidly, like a prau,

abundant be the blessing upon these storehouses, placed beside each other.

27 The offering meal to the gods is often placed on banana leaves; it is set down at the north-east side of the offering place.

28 siayok $a=$ joined together by a yoke.

The Toradja are well aware of the similarity between the up-curving ends of the longitudinal and cross beams of the walls of the rice granary and the upcurving ends of a prau. These huge granaries are completely covered with carvings, as is the underside of the floor upon which the rice is stored. The rice that is placed on the floor is thus treated with the reverence due to it. 
29 Inanna tallu bulinna, patindoanna ke'te' tallu eterna.

30 La narinki simbolon manik, la naala lokkon loerara'.

31 Anna pebusaruß乃ui panampa to Bone, napetirimba bupandenni pa'kombon to Balanda.

32 Napebusarußßui to ma'puduk mundan, napebukaju-aukki to ma'illon karumisik.

33 Narandanni petaa mammi' simbolon manik, nabirini lale' sanda marasa lokkon loerara'.

34 Kurre sumaßa'na te bolu kaju sitammu ura'na, saba' parajanna te kalosi ponno issinna sola kapu' ma'lumpa bumbunan.

35 Kurre sumaßa'na te tuak massari dadik, saba' parajanna te tagari sazujun.

36 Sundunmo kukurre sumaßa' mintu' la napapake surasan tallaß, upu'mo kupole paraa roßka-roßkana ra'buß diaßgilo, nasielleran

karidisan panduß balo.

37 Apa denpi manii kusala kukurre sumana', denpi manii kulenda kupole paraa.

30 simbolon manik: knot of hair, shining like beads, and lokkon lo-erara': roll of hair, hanging down, like a golden neck chain, are both honorific designations for a woman of rank.

31 The idea in this strophe is that the coins long for the rice; they desire that rice be bought with them.

32 These are parallel expressions for the buffalo. The wood of the kayu auk, a kind of tree, is very much liked by buffaloes: they lick it greedily and bite at it hungrily. 
29 The place of the three-eared [rice], the resting place of the cut one, branched in three.

30 The knot of hair, shining like beads, will pick it up, little by little, the roll of hair, hanging down, like a golden neck ornament, will take it therefrom.

31 That which is shaped by the people of Bone, now smells the agreeable fragrance of it,

that which is made by the Dutch, now receives its wafted sweetsmelling perfume.

32 The ones with lips like those of the wild duck, now smell the agreeable fragrance of it,

the ones whose noses are like that of a small wild duck, smell the perfume like that of the wood which entices them.

33 The knot of hair, shining like beads, sets out for it with an enchanting smile,

the roll of hair, hanging down, like a golden neck ornament, goes to it, laughing most sweetly.

34 Hail to these betel leaves, with the nerves that come together, abundant be the blessing upon these well-filled areca nuts, and on the lime, like bubbling cream on milk.

35 Hail to the palm wine, looking like white cream, abundant be the blessing upon the bunches of fragrant grass.

36 That is the completion of the things for which I invoke the blessing, everything used at the offering on the small offering table of bamboo struts on which a design is cut,

now I have come to the end of the benedictory prayer for all the things with which the bamboo with incised lines is adorned, to which must be attached the leaf ribs of the sugar palm wrapped round with small pieces of blood-smeared kapok.

37 Perchance I have missed out something in the speaking of the invocation for blessing,

mayhap I have omitted something in the invoking of the benediction.

34 The nerves of the betel leaf seldom touch each other.

35 massari dadik = containing the fat of the milk.

tagari is a fragrant kind of grass (Dianella ensifolia), the root and stems of which are burnt as incense at the offerings to the gods.

36 ra'bun (Mal. rěbuß) = old bamboo shoots which are no longer eatable. In the poetical language, ra'bun is the parallel of tallan = bamboo.

The leaf ribs of the sugar palm, wrapped round with kapok in different places, which are mentioned in this strophe, are set upright at the top of the bamboo struts of the offering table 
38 Apa umbai limbormo nene' bußa' mellao lani'

inde barira banuanna to ma'rapu tallaß,

umbai tasikmo to dolo kapuaßanna to maßanna saßka' inde rampe matampu'.

39 La kupa'buaßi sanda randanna, ke den kusala kukurre sumana', la kupa'kolakanni sanda birinna, ke den kulenda kupole paraa.

40 Anna nene' mazanna sazka'mo umpasirundunan buloi, anna to dolo lentenan panikuan umpasitete malaa'i.

41 Limbon dukamo Puaß Matua lan rampe matallo, la kupa'buani sanda birizna, tasikmo To Kaubanan lan kabu'tuan kulla', la kupa'kolakki sanda randanna.

42 Puaß Matuamo la umpasirundunan buloi, To Kaubanan la umpasitete malaa'i.

43 La kubalik bombaßmo te randan pudukku sule maßkali oto', la kupasule uaimo te dara' leßko lilaku tibalik ma'poßka parompon.

44 E, Puan e! e Puaß e! e Puaß e! Puan Matua dao taßßana lani',

45 To Kaubanan dao masuaßgana to paozanan, Puan Bassi-bassian, Puaß Ambo-amboan!

46 Deata taßßzana lani', puaß barrena allo.

47 Deata kitiro tuka', puaß kimanta lu laß̧an.

38 limbon $=$ pool; large fish pond. In the poetical language it means being full up, being crowded together in one place.

tasik $=$ sea.

39 sanda randanna and sanda birimna $=$ right to the edge.

$k u p a^{\prime} k o l a k a n n i=I$ cast it before them; it is derived from kolak, a missile made of bamboo. The end of it is split and a small stone or a plug of earth is wedged therein. It is used for slinging stones or earth.

40 ullentenan panikuan: the turning over of the shuttle in the loom.

umpasirundunan buloi: to do as straight as an internode of thin bamboo; figuratively it means to do exactly in the right way.

tete: small bridge made of two or three bamboo culms; figuratively, it means fixed order; tetena batin: the fixed order of the dirge; umpasitete $=$ to put in the proper order. 
38 But perhaps the ancestors, as the first men who descended from heaven, have assembled here, near the bamboo fence round the space under the house of those who are numerous as bamboo culms,

it may be that the forefathers, revered as lords, the guardians of the Rules, are gathered in a multitude at the West side.

39 So that I may surrender it to them, from the beginning to the end, if $I$ have missed out something in the speaking of the invocation for blessing,

so that I may cast it before them, from start to finish, if I have omitted anything in the invoking of the benediction.

40 Then may the ancestors, who watch over the Rules, put it in order in the proper manner,

then may the forefathers, who weigh matters, arrange everything in the right way.

41 Puan Matua has come with them in the East, let me surrender it to him, from the beginning to the end, To Kaubanan is with the multitude of them, let me cast it before him, from start to finish.

42 May Puan Matua put it in order in the proper manner, may To Kaubanan arrange everything in the right way.

43 Let me turn back the tips of my lips, as do the waves, to unearth what was at the start,

let me take back all the words I have spoken, in their regular order, as water flows back, to dig up what was in the beginning.

44 O Lord! O Lord! O Lord!

O Puan Matua in the centre of the firmament!

45 O To Kaubanan in the highest part of the all-covering roof, Puan Bassi-bassian, Puan Ambo-amboan!

46 God at the heart of the firmament, lord of the shining sun.

47 The god whom we see ascending, lord whom we behold rising upwards.

malaa $=$ having long internodes. In the poetical language it is the parallel of bulo $=$ thin bamboo.

41 For remarks on Puan Matua and To Kaubanan, see the introduction to the consecration invocation for the buffalo. Puan Matua $=$ The Old Lord, God in the Centre of the Firmament.

43 lenko lila $=$ words spoken in regular order. ma'ponka parompon $=$ to turn over the ground by digging.

45 to paozanan = that which shades, covers; it is the parallel of lani = firmament For remarks on Puan Bassi-bassian and Puan Ambo-amboan, see the introduction to the consecration invocation for the buffalo. 
48 Deata napabußa' toßkon nene' mendeataßki, ke bendanni kapemalaran, puaß tipamulanna napaunnesun to dolo kapuaßaßki, ke tunannani

kapa'urande-randean.

49 Deata umpasisuka' boni allo, puaß umpasikararoan tanda malillin masian.

50 Deata umpatunara padaß, puaß umballa' rante kalua'.

51 Deata ußgaraga uma ma'kambuno lumu', puan urrante panompok doke-dokean.

52 Deata untanan pesuran banne sirenden, puaß unnosok pa'tagarian.

53 Deata lumumbaß lani', puan sumonko' to palullußan.

54 Deata tumari' allo, puan lumepon bulan.

55 Deata tumampa tau, puan kumomboß to sanda raßka'na.

56 Deata ußkalumpena sadaß, unkombon mata maloton.

57 Deata tumampa to ma'puduk mundan, puan kumombon to ma'illon karumisik.

58 Deata tumampa pare tallu bulinna, puaß kumombon ke'te' tallu eterna.

59 Deata tumantan gaun, puaß rumembon salebu', umpabe'daß koro-koro.

$48 k a p a^{3}$ urande-randean $=$ the act of holding something on the flat of the hand, and see 650 .

49 umpasikararoan $=$ to weigh by using coconut shells (kararo) as a measure, and see 608.

50 umpatußara $=$ to lay something on its back. umballa $=$ to unroll.

A stone is sometimes set up at the offering places mentioned in strophe 52 and three rice plants are left there.

pa'tagarian = the place where the fragrant grass is burnt; here it is the parallel of pesuman banne $=$ the place on the ricefield where the offerings are laid for the new plantation. 
48 The god whom our divine ancestors requested to be the first to sit down with us, when the offering stood ready,

lord whom, in the beginning, our forefathers, revered as lords, begged to be the first to take a seat here, when the offering gifts had been prepared.

49 God who balanced the period of the day and the night against each other,

lord who marked out the mutual relation between the dark time and the light time.

50 God who laid out the ricefields, lord who spread out the broad plain.

51 God who formed the wet ricefields, with duckweed as a sunshade, lond who spread out level the dyked sawahs, full of water plants.

52 God who delineated the offering places, one after the other, in the ricefields,

lord who marked out the places on the ground where the fragant grass is burnt.

53 God who arched the firmament downwards, lord who curved the all-enfolding as the covering roof.

54 God who fashioned the sun as a disc, lord who cut out the moon as a circle.

55 God who created mankind, lord who formed the one whose limbs are complete.

56 God who gave the mouth its round shape, lord who formed the pupil of the eye.

57 God who fashioned the one with lips like those of the wild duck, lord who created the one whose nose is like that of a small wild duck.

58 God who formed the three-eared rice, lord who shaped the cut one, branched in three.

59 God who made the clouds to scatter, lord who separated the mists from each other, who caused the thick clouds to rise up.

53 lumumban $=$ to bend forward.

sumonko' $=$ to make as a covering: for exemple, a roof.

somko' = head covering.

to palulluman $=$ that which envelopes; here it is the parallel of lani' $=$ firmament.

55 to sanda ranka'na = to ganna' tarunona $=$ the ones whose fingers are complete;

both are poetical expressions for human beings.

56 mata maloto $3=$ the black [of the] eye.

mata mabusa $=$ the white [of the] eye. 
60 Deata rumapa guntu', puaß rumanda galugu.

61 Deata umbanko tindak sarira, puaß unna'ta' taraue.

62 Deata unnambo' bintoen tasak, puaß ussearan asi-asi deata.

63 Deata rume'pe' Bußa', puaß ußkalumpera Sadaß.

64 Deata undandan Lemba, puaß umbato' Tallusituru'.

65 Deata tumoke' manukna Lapandek, puaß unnaninni londonna Poß Tulaßdidi'.

66 Iamo kitiro tuka' lan dannari lambe', ke umparokkokan banne malapu'.

67 Iamo kimanta lu laß̧̧an lan paseko malillin, ke ussearankan ka'do sama lele.

68 Kipopentaunan taß balle, kipodaßkanan taß pele-pele.

69 Deata saßpapa'na pole laßi' laßzan, puan duaß papa'na lani'.

70 Deata tallun papa'na pole lani', puaß a'pa'na papa'na lani'.

71 Deata limanna papa'na lani', puaz annanna papa'na laßi'.

72 Deata pitunna papa'na lani', puaß karuanna papa'na lani'.

73 Deata kaseranna papa'na lani', ganna' saßpulo duanna papa'na lazi'.

74 Taß dilambi'na, taß didete'na.

62 tasak $=$ ripe.

$63 \quad B u n a^{\prime}=$ First, Beginning. Perhaps the Pleiades have this name because they are consulted when it is intended to commence work on the ricefields when the new rice-planting year begins.

I do not know to which constellation Sadan refers: sadan $=$ mouth.

$64 l e m b a=$ a carrying pole; the pole has a load hung on each end and it is carried across the shoulder.

"The three stars that follow each other", probably means the three stars in Orion's Belt. 
60 God who made the thunder to roll, lord who caused the storm to break.

61 God who curved the rainbow, lord who spanned the arch of the sky.

62 God who scattered the yellow-shining stars, lord who spread abroad the lights of the gods.

63 God who made the Pleiades to stand together, lord who fashioned the curve of the constellation shaped like a mouth.

64 God who set the stars of the Great Bear in a row, lord who placed in a line the three that follow each other.

65 God who hung up the Fowl of Lapandek, lord who made the wind to blow over the Cock of Pon Tulandidi'.

66 Whom we see ascending in the long late part of the night, when we throw down the well-filled seed grains.

67 Whom we behold rising upwards between evening and midnight, when we strew the rice seed on all sides.

68 Whom we have as the one who, without error, determines the regular seasons, who is to us a truthful measurer of time.

69 God of the first layer of the firmament, lord of the second layer of the firmament.

70 God of the third layer of the firmament, lord of the fourth layer of the firmament.

71 God of the fifth layer of the firmament, lord of the sixth layer of the firmament.

72 God of the seventh layer of the firmament, lord of the eighth layer of the firmament.

73 God of the ninth layer of the firmament, of the twelfth layer of the firmament, in completeness.

$74 \mathrm{He}$ is inaccessible, he is unapproachable.

65 "The Fowl of Lapandek" and "The Cock of Pon Tulandidi", are the names of a mythical creature. This cock was struck by Pon Tulandidi' and he then flew up into the sky. He is said to hang on the moon. Sce, H. van der Veen, "Sa'danToradja'se Volksverhalen", Verhandelingen Bataviaasch Genootschap van Kunsten en Wetenschapp, Vol. 62, Part 2, p. 63-70.

67 paseko = sap wood of a tree; the layer of wood surrounding the heartwood.

68 dankan = a span; daykanan = measure of the size of a span. 
75 Ma'guluß-gulußanna, pidun-pidunanna, saliußanna.

76 Massaloko batunna, massondoz kandaurena, ma'tampak pelole'na.

77 Taß nalambi' randan dipudukna, taß sipolili'ki nakambio santuß.

78 Tan nadete' ia dara' lenko lilana, taß sipogontinki nako'bi' riti bulaan.

79 Randan pudukki kami ullambi'i nakambio santuß.

80 Dara' lenko lilaki kami undete'i nakobi' riti bulaan.

81 Ma'lolok didinna pole laßßan, ma'eru' balusunna, ma'tampak telo-telona.

82 Deata toßkon lan bilikna dao, puaß unnesuß lan kulambunna.

83 Deata ma'rindin maa', puaß ma'kulambu doti lani'.

84 Deata disura' toßkonanna, puaß dieron sissareanna.

85 Dibulinton esuß-esußanna. Iamo Puan Matua to, iamo To Kaubanan.

86 Iamo Puan Bassi-bassian, iamo Puaß Ambo-amboan.

87 Bunka'komi ba'ba manikmi la dieranni kapuran paßan, killankomi pentiroan bulaanmi la dipelalanni pelambaran dibaolu.

88 Pa kamumo deata mamase, kamumo puaß sa'pala buda.

76 "like... of beadwork": these pieces of beadwork are the kandaure (see note 8) hung up in the reverse way to that when worn by the women, hence they are narrow at the top and wide at the base.

77 sipolili'ki $=$ those who regard our region as theirs.

78 sipogontinki $=$ those who regard our boundaries as theirs.

79 nakambio $=$ they flutter their finger tips and try to touch them.

84 eron $=$ wooden coffin. It is shaped like a rice-stamping block and is adorned with carving. In olden times, the corpses of people of high rank were laid in such coffins which were then placed in holes in the rocks. These designs are carved in the earliest known style.

sissarean $=$ that which one leans against. 
75 In his sublimity he is not to be beheld, he is in blue haziness, in thin mists.

$76 \mathrm{He}$ has a zenith going to a point and tipped with a stone, it is as a piece of beadwork, wide-based and narrow at the top. its point is like the sharp folded young leaves of the sugar palm.

77 The tips of the lips of the ones who do not belong to our region, fingering the strumming instrument, do not reach unto him.

78 All the words spoken, in their regular order, by the ones who are not of our fixed territory, plucking the golden strings, do not penetrate unto him.

79 But the tips of our lips, fingering the strumming instrument, do reach unto him.

80 All the words spoken by us, in their regular order, plucking the golden strings, do penetrate unto him.

81 He has a zenith like that of the leaf rib of the sugar palm high above, it tapers to a thin end, like an armband of white shell, its summit is at infinity.

82 God who dwells in his abode on high, lord who is seated behind his curtain.

83 God who is enfolded within a wall of an old short wide cloth, lord who is enclosed inside a curtain of an old short wide fabric with a cross motif on it.

84 God on whose clan house designs are cut, lord whose wall is adorned with carving, like that on a wooden chest for the dead.

85 His throne is decorated with the carving of a young frog.

86 That is Puan Matua, that is To Kaubanan, that is Puan Bassi-bassian, that is Puan Ambo-amboan.

87 Open thy door of beadwork, so that a step may be set to it, by the strewing of lime for the betel quid, throw open thy window, in order that a ladder may be lent against it, by the laying of betel leaves, one by one.

88 For thou art a merciful god, thou art a lord great of compassion.

87 dieranni $=$ it was provided with a step. baolu is the old poetical form of bolu = betel.

Verh. dl. 45 
89 Aßku tundan sandeatammi dion kalambunan allo, deata sanda karua, kurujaß saßkapuaßammi dion kabotoan kulla', puaß ganna' bilaßbilazanna.

90 Deata sanda karua lo' enkokna padaß, puaß ganna' bilaßanna lo'.

91 Deata sanda karua lan matallona lani', puaß ganna' bilaßanna lan kadellekan kulla'.

92 Deata sanda karua daa ulunna lani', puaß ganna' bilananna daa karopokna pandan matari' allo.

93 Deata sanda karua lan taßß̧ana laßi', puaß ganna' bilaßanna lan masuaßgana to paoßanan.

94 Pa kamumo puaß sa'pala buda, silelemokomi kupalilin kanan kukambio santun, upu'mokomi kutamben bala tedon kuko'bi' riti bulaan.

$95 \mathrm{~Pa}$ denpakomi manii nasala te randan dipudukku, pa ganda'ka maparek tannun?

denpakomi manii nalenda te dara lezko lilaku, pa dionra'ka matintian kala'?

96 Apa Puaß Matuamo la kupa'buani sanda randanna, To Kaubananmo la kupa'kolakanni sanda birinna.

97 Kamumo randan to mamma' sitamban saßdeatammi, ke denpi kusala buntummi, kamumo To Kaubanan kupairin to matindo sikorok london saßkapuaßammi, ke denpi kulaßkun ma'tanetemi.

$89 k u l l a$ ' $=$ shining, glittering; the poetical designation for the sun

90 enkokna padan: the back part of the earth, the most southerly part; enkok=tail Strophe G 49 of the offering praver at the ma'bubun rite has: "the golden back of the firmament", instead of "the back of the earth".

92 karopok = cranium, skull: it is the parallel of the word $u l u=$ head, the beginning, which occurs in the first half of the strophe.

pandan: determined by agrecment.

matari' allo $=$ cut round like the disc of the sun; matari' $=$ cut round.

94 kutamben bala tedon $=$ I stack up like the beams of the enclosure of the buffaloes' stall. The beams are laid across each other, the one pair being placed transversely on the pair lying beneath.

95 gan =kan: with a following adjective it means so, so much: gan maparek tannun $=$ as dense as a woven cloth.

tintian kala': the heddle to which the warp threads are attached. The meaning of the lines in the strophe is: that when the heddle is lifted, every thread attached to it is raised. But he who summons the gods is not like the warp because it is possible for him to miss out one of them. 
89 Let me now awaken the gods who accompany thee at the place where the sun descends, the gods, all eight of them,

let me arouse the ones, with thee, revered as lords, where the shining one sinks down, the lords, complete in number.

90 The gods, all eight of them in the South, at the back of the earth, the lords in the South, complete in number.

91 The gods, all eight of them in the East of the firmament, the lords where the shining one ascends, complete in number.

92 The gods, all eight of them in the North, the head of the firmament, the lords in the North, complete in number, at the upper part of that which lies stretched out, round, like the disc of the sun.

93 The gods, all eight of them in the centre of the firmament, the lords, complete in number, in the highest part of the all-covering roof.

94 Round thee now, lords great of compassion, have I gone, from the right, fingering the strumming instrument, summoning thee, I have come to the end of calling everyone of thee, plucking the golden strings, from low unto high.

95 Perchance there are some of thee whom the tips of my lips have forgotten to mention; that is because I have not been as complete as a piece of closely-woven cloth,

mayhap there are some among thee who have been overlooked in the words I have spoken, in their regular order; the reason is that I have not been amidst them, like the narrow bar that goes between the separated warp threads.

96 Then to Puan Matua do I surrender it, from the beginning to the end, before To Kaubanan do I cast it, from start to finish.

97 Wilt thou then, as the first in the row of the sleeping ones, call thy co-gods, from here and from there, if I have been in default against thy mountain?

To thee, To Kaubanan, do I address myself, as the foremost of the slumbering ones, to make heard the summons to and fro, as the cock calls the hens, if I have been neglectful of thy high hill.

97 kamumo kupairin $=\mathrm{I}$ take thee as being the one on the extreme end of the row. The sleeping ones and the ones who are lying down, who are summoned, awakened by this invocation and are invited to proceed with their gifts (blessings) to the offering place and to sit down on the tjendana tree (str. 122), are the gods.

randan $=$ edge.

buntummi $=$ thy mountain. 
98 Apa silelemokomi kupalilin, kanan kukambio santuß, upu'mokomi kutamben kalumbassik kuko'bi' riti bulaan.

99 Garagakomi sanda silili' iti' taßßana lani', tampamokomi sanda sigontin lan masuangana to paozanan.

100 Ammi garaga sankederan, ammi tampa santiaßkaran.

101 Ammi sipadolo-dolomi, ammi sipataßßа-taßßami, sipaundi-undimmi.

102 Apa da mima'kambelaß-belaß, da mima'bantala-tala.

103 Pamagasai to' talinammi, paturrukki lamba' beluakmi.

104 Ammi pokinallo ilalan takinan pia, ammi pobokon dilambanan selleran lotoß ulu.

105 Ammi pokinallo ilalan ma'bala tedoß, mipobokon dilambanan ma'paßkuß karambau.

106 Ammi pokinallo ilalan pare tallu bulinna, ammi pobokon dilambanan ke'te' tallu eterna.

107 Ammi pokinallo ilalan sarita to lamban, ammi pobokoß dilambanan maa' to unnoron.

108 Ammi pokinallo ilalan doti laßi' tuo balo', ammi pobokon dilambanan seleß tumbo kulau'.

109 Ammi pokinallo ilalan gajaß ditarapani, ammi pobokoß dilambanan kandaure salombe'.

110 Ammi pokinallo ilalan patoko ma'dandan, ammi pobokoß dilambanan rara' tikui kollon.

98 kutamben kalumbassik = I have laid thy ends across each other like the arcs of split bamboo; these act as an enclosure and are stuck end-over-end in the ground.

102 ma'kambelan $=$ naked.

103 The meaning here is that the gods must take provisions with them. The idea is that these provisions are carried as women do loads, on their backs. The load is supported by a band passing across the forehead and above the ears.

110 patoko $=$ neck chain. Both the patoko and the rara' are neck chains worn by women. The patoko is the larger. It consists of large heavy oblong beads which are made of a dark brown resin overlaid with gold. The rara' has these same heavy beads but between each bead there are a few small ones; and see 2 . 
98 Round thee now have I gone from the right, fingering the strumming instrument, summoning thee,

I have now come to the end of calling thee, plucking the golden strings, from the one end to the other.

99 Summon now a gathering, consisting of all the gods in the centre of the firmament,

bring about a meeting, in which are included all in the highest part of the all-covering roof.

100 Arrange a start complete, from a united departure.

101 Let the ones who stand in the front go together and lead the way, the ones in the middle go together, and the ones at the end go together.

102 But thou shalt not go empty-handed, thou shalt not be without anything.

103 Make heavy that which rests above thine ears, let it make tangled the hair of thy head.

104 As sustenance for the journey, take the carrying of offspring on the hip,

as provisions on the way, take the bearing of a human being at the waist.

105 As sustenance for the journey, take the stalling of the buffaloes, as provisions on the way, take the stabling of the kerbau.

106 As sustenance for the journey, take the three-eared rice, as provisions on the way, take the cut one, branched in three.

107 As sustenance for the journey, take the old long narrow blue woven cloth, with the design of men fording a river,

as provisions on the way, take the old short wide fabric, with the pattern of swimming men.

108 As sustenance for the journey, take the good fortune-bringing old short wide woven cloth, with the cross motif on it,

as provisions on the way, take the prosperity-bearing fabric with the seley motif on it.

109 As sustenance for the journey, take the gold kris of great size, as provisions on the way, take the piece of beadwork, with the cords hanging low.

110 As sustenance for the journey, take the large neck chain, with the beads strung in a row, as provisions on the way, take the gold chain circling the neck. 
111 Ammi pokinallo ilalan lola' tuo balo', ammi pobokon dilambanan indo'na ianan.

112 Ammi pokinallo ilalan tindo maelo, ammi pobokon dilambanan mamma' makatozan-tonan.

113 Ammi pokinallo ilalan lindo masakke, ammi pobokon dilambanan rupa maradindin.

114 Ammi pokinallo ilalan mendaun sugi', ammi pobokon dilambanan mentaßke ianan.

115 Mintu' to la napoinaa te to ma'rapu tallan la mipokinallo ilalan, makalima'na to la napoba'teß te to ma'kaponan ao' la mipobokoß dilambanan.

116 Kamumo deata mamase, kamumo puaß sa'pala buda.

117 Bunka'mokomi ba'bana lani', killazmokomi pentiroanna to paozanan.

118 Ammi bozsoran eran manikmi lan di Kesu', ammi randukan kalisuan bulaanmi lan di Beloara'.

119 Ammi ma'lalan tindak sarira, ammi ma'lambanan taraue.

120 Apa da milempan to minda-to minda, dapa mima'lalan tau laen.

121 La rampo lembankomi inde tizo banuanna to ma'rapu tallaß, la tu'tun koli-kolikomi indete paßrante manikna to ma'kaponan ao'.

122 Ammi torro bulaan dao sendana sugi' ma'paßan-paßan, ammi unnesuß batan-batan dao kaju mentaßke ianan ma'damerakmerak.

123 Ammi paßan bolu sitammu ura'na, kalosi ponno issinna, kapu' ma'lumpa bumbuzan.

111 lola' $=$ large armband. This ornament has short thin sticks of gold projecting all round it and a small precious stone is set in the extremity of each stick. indo'na ianan = Mother of the Possessions; it is the parallel of lola'; the band from which gold sticks project being the 'Mother' and the precious stones the 'Possessions'.

112 makatozan-tonan = actual, true.

118 The clan house for which the merok feast is held is in the Kesu' territory, in the Rantepao country. The founders of this clan house are, according to tradition, descendants of Puan riKesu' $=$ The Heaven Born, who descended onto the Kesu' rocks. Beloara' is a region abutting onto the Malenon rocks, it is in the area of $B a^{\prime} t a n$, a village in the Kesu' territory.

120 to minda-minda $=$ any people whatsoever.

$122 m a^{\prime}$ damerak-merak $=$ colouring the mouth red. 
111 As sustenance for the journey, take the large good fortune-bringing armband, with the small gold sticks, as provisions on the way, take the Mother of the Possessions.

112 As sustenance for the journey, take an auspicious dream, as provisions on the way, take a pregnant nocturnal vision.

113 As sustenance for the journey, take a countenance full of goodwill, as provisions on the way, take a benevolent appearance.

114 As sustenance for the journey, take a quantity of riches, like foliage, as provisions on the way, take a manifold branching of precious things.

115 As sustenance for the journey, take thou everything that will be in the thoughts of the clan members present, numerous as bamboo culms, as provisions on the way, take thou all the things of which the ones whose group always increases like a bamboo stool, are mindful.

116 Thou art merciful gods, thou art lords great of compassion.

117 Open the door of thy sky, throw open the window of the all-covering roof.

118 So that thy stairs of beadwork may be lowered onto the Kesu', in order that thy golden stairs may be let down in Beloara'.

119 Then shalt thou take the rainbow as thy path, thou shalt make thy way along the arch of the sky.

120 And thou shalt not branch off onto the one way or the other, thou shalt not take the path of other people.

121 So that thou arrivest here, at the forecourt of the house of the clan members, numerous as bamboo culms, like the coming of a prau, in order that thou comest here, to the court, which shines like beads, of the ones whose group always increases like a bamboo stool, like a small boat bumping [against the landing stage].

122 Then, glittering like gold, shalt thou take thy seat on the richly laden tjendana tree, while chewing the betel quid, then, shining like tiny round gold beads, thou shalt sit on the tree whose branches are full of precious things, whilst thou makest thy mouths red.

123 Then shalt thou partake of the betel leaves with the nerves that come together, and well-filled areca nuts, and lime, like bubbling cream on milk.

batan-batan = tiny round gold beads; for example, the small beads between the large beads of the rara', the neck chain.

"... while thou makest thy mouths red", refers to the red saliva produced by the action of the lime on the betel fruit or the leaf when the betel quid is chewed. 
124 Apa kamumo deata mamase, kamumo puaß sa'pala buda.

125 Apa tumanan rampa'pokomi talina duammi, apa lumidan maja-majapokomi suliz patomalimmi.

126 Apa denni manii te kupasibekoan, denni manii te kupasikairian.

127 Denni manii dolona kupaundinna, denni manii undinna kupadolona.

128 Kamupa la kupa'buani sanda randanna la umpasirundunan buloi, kamupa la kupa'kolakanni sanda birinna la umpasitete malaa'i.

129 Ammi bulo sazlampa to tumampaku, ammi tallaß taß kelesoan puaß to mangaraganku,

130 umbanunni ada' randan pudukku, la usserek bannaß nene' mendeatanna titanan tallu.

131 Ammi motokki lila pa'pakilala lezko lilaku, la mibille pantasi to dolo kapuazanna samba' batu lalikan.

132 Ammi baßunni dukai ada' te to ma'rapu tallaß, siria bozana gau'.

133 Mimotokki lila pa'pakilala te to malimbo kaluku, sisaladan samara bisara.

134 Apa denni manii alukna bozana gau' sibekoan, den manii saßka' beloß-beloßanna te samara bisara sikairian.

135 Den manii dolona dipaundinna, den manii undinna dipadolona.

136 Kamupa la dibuani sanda randanna la umpasirundunan buloi, kamupa la dipa'kolakanni sanda birizna la umpasitete malaa'i.

125 sulin = flute, pipe; it is the parallel for ear.

129 bulo sanlampa = straight internode of thin bamboo; here it means: straight as an internode of thin bamboo. tallay tan kelesoan $=$ thin bamboo culm without nodes.

130 "the three belonging together", are the buffalo, the pig, and the fowl.

133 malimbo $=$ gathered together in a circle; samlimbo $=$ a collection of something; for example, a stool of bamboo culms. 
124 For thou art merciful gods, thou art lords great of compassion.

125 Bend now thine ears sympathetically, incline thy flutes on either side in a friendly way.

126 If I have summoned the one or the other in an incorrect manner, if $I$ have not joined the one with the other in the proper way.

127 If I have put the first one last, if I have placed the last one first.

128 Then I surrender it to thee, from the beginning to the end, to put it in order in the proper manner, then I cast it before thee, from start to finish, to arrange everything in the right way.

129 So that thou, my creator, in the correct order, so that thou, Lord, my maker, without irregularity,

130 Shalt bring to the tips of my lips the recollection of the arrangement of the traditional way,

so that, one by one, mention may be made of the divine progenitors of the three that belong together.

131 So that thou shalt cause to arise in the enumeration by my tongue, in regular order, speech that will bring recollection to the mind, in order that mention shall be made separately of each of the progenitors, revered as lords, of the ones that belong together, like the three stones of the hearth.

132 Thou shalt also recall the tradition of those present, the clan members, numerous as bamboo culms, who together care for the most excellent of feasts.

133 So that thou shalt cause to arise in those who are gathered here together in a group, in order to maintain the most precious adat performances, speech that will bring recollection.

134 For it may be that rites of the most excellent of feasts are disjointed, perhaps the required parts of the arrangement of the most precious adat performances have not been fitted together properly.

135 It may be that the first one has been put last, perhaps the last one has been placed first.

136 Then will it be surrendered to thee, from the beginning to the end, so that thou canst put it in order in the proper manner, then it will be cast before thee, so that thou canst arrange everything in the right way. 
137 Namasalossok te bozana gau' mitarima pala', anna matinuru' te samara bisara misarande paraja.

138 Natontoß te kapemalaran sisompo lu laßnan dio to ma'rapu tallaß, nasalaßßan-laßßanna mendaun sugi' ußkallo taß̧ana laßi'.

139 Natu'tun sakendek-kendekna sipembuleanan pa'urande-randean, dio tondon to batanna to malimbo kaluku, sakendek-kendekna mentanke ianan usse'pa' barrena allo.

140 Apa la kubalik bombanmo te randan dipudukku sule mazkali oto', la kupasule uaimo te dara' leßko lilaku tibalik ma'ponka parompoß.

141 Anku tundan saßdeatammi inde dion maririnna litak, kurujaß sankapuanammi inde dion manapi'na tana.

142 Deata dibaßunni banua rokko, puaß diosokki a'riri sanda pati'na.

143 Deata sipatu botto ulunna dipolalan dion mai, puaß sidara' pa'barusanna diolai.

144 Deata patulak tua', puaß pasarande paraja.

145 Deata parande pala', puan pasarande taruno.

146 Deata pasali-sali, puaz patuma'bakan.

147 Deata umpasisuka' boni allo dion, puaß umpasikararoan tanda malillin masiaß.

148 Deata umpatußara padaß, puaß umballa' tana kalua'.

149 Deata ußgaraga uma ba'kambuno lurnu', puaß urrante panompok doke-dokean.

141 maririnna litak $=$ the yellowness of the soil.

This expression refers to the natural large holes or clefts in the ground. maßapi'na tana $=$ the layers of the earth lying on each other. Both these expressions mean the lower layers of the earth, the layers of the underworld. An other word for the underworld is: to kengkok, see 177.

142 deata dibanunni banua rokko= god upon whom the houses are built; i.e., Pon Tulakpadan = Lord Who Supports the Earth; he who lives under the earth. unnosok = to stick in a hole; to plant.

143 pa'barusan = the parting in the middle of the hair.

146 patuma'bakan = the structure of slats laid over the cross beams and on which the floor rests.

"Who places himself as the floor", i.c., upon whom the earth is stretched. 
137 So that thou mayest receive on the palms of thy hands, unhindered, this most excellent of feasts,

in order that thou mayest take on the flat of thy hands, unhampered, this most precious adat performance.

138 May these offerings of the clan members, numerous as bamboo culms, be borne on each other on high on the shoulders, may they reach the centre of the firmament, always increasing in luxuriance and abundance, like foliage.

139 May they always rise, and ascend to the summit in their magnitude, excelling each other in the size of the gifts, at the side of those who are gathered round in a group, like coconut palms, in the forecourt,

may they continue to increase in quantity, like the branches of the tree, and reach to the shining sun.

140 Now will I turn back the tips of my lips, as do the waves, to unearth what was at the start,

now will I take back all the words I have spoken, in their regular order, as water flows back, to dig up what was at the beginning.

141 Let me now awaken thy co-gods below us, in the clefts of the earth, let me now arouse the ones, with thee, revered as lords, beneath us, in the layers lying on each other in the depths of the ground.

142 God below us, upon whom the houses are built,

lord upon whom the poles, which are cut to the correct size, are erected.

143 The god upon whose skull it is fitting for us to walk, lord over the middle of whose head it is seemly to tread.

144 The god who is the support of prosperity, lord who carries the welfare [of people] on the palms of his hands,

145 God who holds the protecting [of people] on the flat of his hands, lord who spread out his fingers as a floor beneath mankind.

146 God who placed himself as the floor of the earth, lord who is the under layer of it.

147 God below, who balanced the period of the night and the day against each other,

lord who determined the mutual relation between the dark time and the light time.

148 God who laid out the ricefields,

lord who spread out the broad plain.

149 God who formed the wet ricefields, with duckweed as a sunshade, lord who spread out level the dyked sawahs, full of water plants. 
150 Deata untanan pesuran banne sirenden, puaß unnosok pa'tagarian.

151 Deata lumumbaß lani' rokko, puan sumonko' to palulluzan.

152 Deata tumari' allo, puaz rumimba' bulan.

153 Deata tumampa tau, puaß kumombon to sanda raßka'na.

154 Deata tumampa to ma'puduk mundan, puan kumombon to ma'illoß karumisik.

155 Deata tumampa pare tallu bulinna, puaß kumomboß ke'te' tallu etezna.

156 Deata tumantan gaun, puan rumembon salebu'.

157 Deata rumapa guntu', puaß rumanda galugu.

158 Deata umbanko tindak sarira, puaß3 unna'ta' taraue.

159 Deata unnambo' bintoen tasak, puaß ussearan asi-asi dannari.

160 Deata rume'pe' Bußa', puaß ußkalupeza Sadaß.

161 Deata untoke' manukna Lapandek, puaß unnazinni londonna Poß Tulaßdidi'.

162 Deata mamase, puaß sa'pala buda.

163 Deata sanpapa'na rokko, puaß duaß papa'na rokko.

164 Deata tallunna papa'na rokko, puaß a'pa'na papa'na rokko.

165 Deata limanna papa'na rokko, puaß annanna papa'na rokko.

166 Deata pitunna papa'na rokko, puaß karuanna papa'na rokko.

167 Deata kaseranna papa'na rokko, puaß ganna' saßpulo duanna papa'na rokko.

168 Ma'lolok didinna rokko, ma'eru balusunna.

159 "who spread abroad the light of the late part of the night"; strophe 62 reads: "who spread abroad the lights of the gods". 
150 God who delineated the offering places, one after the other, in the ricefields.

lord who marked out the places on the ground where the fragant grass is burnt.

151 God who arched the firmament downwards, lord who created the all-enfolding as the covering roof.

152 God who fashioned the sun as a disc, lord who cut out the moon as a circle.

153 God who created mankind, lord who formed the ones whose limbs are complete.

154 God who fashioned the one with lips like those of the wild duck, lord who created the one whose nose is like that of a small wild duck.

155 God who formed the three-eared rice, lord who shaped the cut one, branched in three.

156 God who made the clouds to scatter, lord who separated the mists from each other.

157 God who made the thunder to roll, lord who caused the storm to break.

158 God who curved the rainbow, lord who spanned the arch of the sky.

159 God who scattered the yellow-shining stars, lord who spread abroad the light of the late part of the night.

160 God who made the Pleiades to stand together, lord who fashioned the curve of the constellation shaped like a mouth.

161 God who hung up the Fowl of Lapandek, lord who made the wind to blow over the Cock of Pon Tulandidi.

162 Merciful god, lord great of compassion.

163 God of the first layer of the earth below, lord of the second layer of the earth below.

164 God of the third layer of the earth below, lord of the fourth layer of the earth below.

165 God of the fifth layer of the earth below, lord of the sixth layer of the earth below.

166 God of the seventh layer of the earth below, lord of the eighth layer of the earth below.

167 God of the ninth layer of the earth below, lord of the twelfth layer of the earth below, in completeness.

$168 \mathrm{He}$ has a zenith like that of the leaf ribs of the sugar palm below, it tapers to a thin end, like an armband of white shell. 
169 Ma'tampak tambulinna.

170 Iamo Poß Tulakpadaß to, iamo puaß parande paduduß.

171 Iamo deata mamase, iamo puaß sa'pala buda.

172 Deata sanda karua dion kalambunan allo, puaß ganna' bilaßanna.

173 Deata sanda karua lo' eßkokna padaß dioß, puaß ganna' bilaßanna.

174 Deata sanda karua lan rampe matallo, puaß ganna' bilaßanna.

175 Deata sanda karua daanna lu, puaß ganna' bilaßanna.

176 Deata sanda karua lan taßßana padaß, puaß ganna' bilaßanna.

177 Silelemokomi kupalilin kanan kukambio santuß, deata to keßkok, upu'mokomi kutamben bala tedon kuko'bi' riti bulaan, puaß to kebali'bi'.

178 Denkomi manii nasalapa te randan dipudukku, denkomi manii nalendapa te dara' lezko lilaku.

179 Kamumo kamu, Poß Tulakpadaß, randan to mamma' sitamban sazdeatammi.a)

193 Mintu' to la napoinaa te to ma'rapu tallaß, mintu' to la napoba'ten te to ma'kaponan ao'.

194 Ammi pabendan eran manikmi, mipate'dan kalisuan bulaanmi.

195 Ammi ola kalimbuan boba, ammi polalan to' mata uai.

196 Ammi so'boi rante, ammi rubak tandun sea-sea.

197 Ammi bille lolokna riu, mipoli' taßke luana.

a) Strophes $180-192$ are similar to strophes $29-114$ of $\mathrm{B}$, and are therefore not included.

177 to kenkok from to keenkok = the ones with tails. to kebali'bi' $=$ the ones with fins. 
169 It goes to a sharp point, like the tip of a lance.

170 That is Pon Tulakpadan, that is the lord who holds [the earth] on the flat of his hands, who bears [the earth] on his head.

171 That is the merciful god, that is the lord great of compassion.

172 Thou gods, all eight of thee, where the sun descends, lords, complete in number.

173 Thou gods, all eight of thee in the South, below, at the back of the earth, lords, complete in number.

174 Thou gods, all eight of thee in the East, londs, complete in number.

175 Thou gods, all eight of thee in the North, lords, complete in number.

176 Thou gods, all eight of thee in the middle of the earth, lords, complete in number.

177 Round thee now, gods of the underworld, have I gone from the right, fingering the strumming instrument, summoning thee,

I have come to the end of calling thee, lords of the subterranean region, plucking the golden strings, from low unto high.

178 Perchance the tips of my lips have forgotten one of thee, mayhap one of thee has been overlooked in the words I have spoken, in their regular order.

179 Wilt thou then, Pon Tulakpaday, as the first in the row of the sleeping ones, now call thy co-gods from here and from there?

193 Everything that will be in the thoughts of the clan members present, numerous as bamboo culms,

all the things of which the ones, whose group always increases like a bamboo stool, are mindful.

194 Wilt thou erect thy step of beadwork?

Wilt thou set up thy golden stairs?

195 In order to take the unfailing well as thy way, with the object of treading the welling-up spring as thy path.

196 Wilt thou make thy way on the field, wilt thou open a path through the broad plain.

197 Wilt thou separate the heads of the grass, and push aside the stalks of the luana grass. 
198 Ammi rampo lembaß indete sa'de banuanna to ma'rapu tallaß, ammi tu'tun koli-koli indete paßrante manikna te to ma'kaponan ao'.

199 Ammi toßkon dao sendana sugi' sitammu sandeatammi ma'paßjan-panan, ammi unnesuß dao kaju mentaßke ianan sirompa' saßkapuaßammi ma'damerak-merak,

200 Ammi metaa mammi', ammi melale' sanda marasa.

Pa kamumo deata mamase, kamumo puan sa'pala buda.

201 Apa la umbalik bombaßmo' randan dipudukku sule maßkali oto', la umpasule uaimo' dara' lenko lilaku tibalik ma'ponka parompon.

202 Aßku tundan saßdeatammi lan kapadaßanna, kurujaß saßkapuaßammi lan kapajan-pajananna.

203 Iamo deata kisano'koran, iamo puaß kisazesuran.

204 Iamo deata kitimba bubunna, puan kisiok meßgulilizna.

205 Deata kilellen kajunna, puaß kiala tanan-tananana, kikalette' utan malunanna.

206 Deatanna pole padaß di Kesu', puanna pole padan di Beloara'.

207 Iamo deata napabuna' toß̧kon nene' mendeataßki lan kapadaßanna ke bendanni kapemalaran, iamo puaß tipamulanna napaunnesuß to dolo kapuanaßki, ke tunannani kapa'urande-randean.

208 Ia dukamo deata malute pakorok london lako saßdeatanna, iamo puaß mabaßko patitian bajan lako saßkapuananna.

209 Deata lembanna pole padaß di Malenon, puazna pole padan di Konkaß.

200 sand $a=$ complete.

$205 k$ ikalette' $=$ we cut it off with the nail.

207 napabuna' $=$ he causes himself to be the first.

209 The Malenon is a cluster of rocks to the south-east of the capital, Rantepao. The complex of the four villages grouped round the rocks, namely, $B a^{\prime} t a n, P a o$, Anin-anin and Tona, are called Tikunna Malenon = those which lie round the Malenon.

Konkan is a protruding spur of rock of the Malenon rocks.

Alambatu $=$ The Stone Rice Granary, is a place on Mt. Kesu' where the stone rice granary of Polopadan, the ancestor, of a number of Toradja territories, stood.

Bualayuk is a region near Alaßbatu. 
198 Then arrive here, at the forecourt of the house of the clan members, numerous as bamboo culms, like the coming of a prau, then come here, to this court, which shines like beads, of the ones whose group always increases like a bamboo stool, like a small boat bumping [against the landing stage].

199 Wilt thou then take up thy seat on the richly laden tjendana tree, and there meet thy co-gods, while chewing the betel quid, wilt thou then sit down on the tree whose branches are full of precious things, together with the ones who, with thee, are revered as lords, whilst thou makest thy mouths red.

200 Wilt thou then laugh in a friendly way, and bestow thy sweetest smile,

because thou are merciful gods, thou art lords great of compassion.

201 But now I will turn back the tips of my lips, as do the waves, in order to unearth what was at the start, now I will take back all the words I have spoken, in their regular order, as water flows back, to dig up what was in the beginning.

202 Let me awaken thy co-gods on the earth,

let me arouse the ones who, with thee, are revered as lords in the open fields.

203 These are the gods among whom we sit together, these are the lords with whom we take our places.

204 These are the gods from whose wells we scoop, the lords from whose bubbling [wells] we draw water.

205 The gods whose timber we cut down, the lords whose produce we pick, whose lush verdure we pluck.

206 Also the God of the Kesu' territory, also the Lond of the Beloara' region.

207 That is the god whom our divine ancestors requested to be the first to sit down with us, when the offerings stood ready, that is the lord whom our forefathers, revered as lords, begged to be the first to take a seat here, when the offering gifts had been prepared.

208 That is the god who summons his co-gods together in a fluent way, as a cock calls the hens together, that is the lord who calls in a skilled manner, as a parakeet shrieks, the ones who, with him, are revered as lords.

209 In addition, the God of the territory of the Malenon region, the Lord of the district of Konkan. 
210 Deata lembanna pole padaß di Alaßbatu, puaßna pole padaß di Bualajuk.

211 Deata lembanna pole padan di Bankudu, puanna pole padaß di Lebani'.

212 Deata lembanna pole padaß di Buntuasa, puanna padaß di Likudeata.

213 Deata lembanna padaß di Sitodo', puanna padaß di Raßgala'bi'.

214 Deata lembanna padaß di Leatuß, puanna padan di Maßkaraßa.

215 Deata lembaßna padaß di Patua', puanna padaß di Mila'.

216 Deata lembaßna padaß di Buntao', puanna padaß di Paniki.

217 Deata lembanna padaß di Ranteaa',

218 Deata lembanna padaß di Pedamaran, puanna padaß di Taßdanun.

219 Deata lembaßna padaß di Pantilaß, puanna padaß di Sumalu.

220 Deata lembanna padan di Palopo, puazna padaß ditana Luwu'.

221 Deata lan tasik kalua', puaz lan bomban malolanan.

222 Deata dio randanna lani', puaß dio lelean uran.

223 Deata lembanna padan di Nangala, puaßna padaß di Bosokan.

$211 B a n k u d u$ is a region on the spur of Mt. Kesu', near the village of Ba'tan. Lebani' is a spur of the Sarira rocks, near the village of Tona in the Kesu' territory.

212 Buntuasa is a small rock of lime in $L a^{\prime} b o^{\prime}$, a complex of villages, in the eastern part of the Kesu' territory.

Likudeat $a=$ The Pool of the Gods, is a water-filled sawah in the above mentioned $L a^{\prime} b o^{\prime}$ group of villages.

213 Sitodo' is a region near the village of Randanbatu, in the Kesu' territory.

214 Leatun is a complex in the north-east of the Sanalla' territory.

215 Patua is a village on the declivity of $\mathbf{M t}$. Bebo, in the above mentioned Leatun complex.

Mila' is a village close to the above mentioned village of Patua'.

216 Buntao' from Buntu ao" "The Mountain where there is much thick bamboo", is a territory in the south-east of the Rantepao country. 
210 As well as the God of the territory of the Alambatu region, the Lord of the district of Bualayuk.

211 And the God of the territory of the Bankudu region, the Lord of the district of Lebani.

212 And further, the God of the territory of the Buntuasa region, the Lor dof the district of Likudeata.

213 And the God of the territory of the Sitodo' region, the Lord of the district of Raygala'bi'.

214 The God of the territory of the Leatun region, the Lord of the district of Maßkarana.

215 The God of the territory of the Patua' region, the Lord of the district of Mila'.

216 The God of the territory of the Buntao' region, the Lord of the district of Paniki.

217 The God of the territory of the Ranteaa' region,

218 The God of the territory of the Pedamaran region, the Lord of the district of Taydanun.

219 The God of the territory of the Pantilan region, the Lord of the district of Sumalu.

220 The God of the territory of the Palopo region, the Lord of the area of the territory of Luwu'.

221 The God in the extended sea, the Lord in the broad waves.

222 The God at the edge of the sky, the Lord at the region from which the rain moves.

223 The God of the territory of the Nangala region, the Lond of the district of Bosokan.

Paniki is a region in the west of the Buntao' territory: it is on the declivity of Mt. Rayri.

217 Ranteaa' is a region near the village of Tandun, in the La'bo' complex; Tandun lies on the southern declivity of Mt. Pedamaran.

218 Mt. Pedamaran (the region where there is resin) lies to the east of the Rantepao country. Taßdanun lies on the declivity of Mt. Pedamaran, in the Buntao' territory.

219 Pantilan is one of the Toradja mountain territories in the Palopo country to the south-east of the Rantepao country. It is one of the four territories of the federation called annan pulona tonkonan = the sixty clan-houses; the chief of the Pantilan adat community has the title of 'isson kalua' $=$ The large rice block."

220 Palopo is the capital of the kingdom of $L u w u$ ' on the Gulf of Bone.

223 Nangala is a territory in the east of the Rantepao country.

Bosokan is a village in the east of the Nangala territory. 
224 Deata lambanna padaß di Pana', puaßna padaß di Sitodon.

225 Deata lembarna padaß di Tondon, puanna padaß di Batulobo'.

226 Deata lembanna padaß di Balusu, puazna padaz di Bonton.

227 Deata lembanna padaß di Sa'dan, puaßna padaß di Bori'.

228 Deata lembanna padaß di Paßli, puanna padan di Malakiri.

229 Deata lembaßna padaß di Tallußlipu, puanna padan di Tagari.

230 Deaata lembanna padaß di Kandeapi, puanna padan di Parindin.

231 Deata lembanna padaß di Barana', puazna padaß di Tikala.

232 Deata lembanna padaß di Batukamban, puanna padaß di Riu.

233 Deata lembanna padaß di Pamabi', puanna padaß di Salusule.

234 Deata lembanna padan di Lempo, puanna padaß di Akuß.

235 Deata lembanna padaß di Sesean, puanna padaß di Lindotau.

236 Deata lembaßna di Buntukarua, puazna padaß di Pa'padanunan.

237 Deata lembanna padaß di Baruppu', puanna padaß di Bettuaß.

224 Paßa' and Sitodon are hamlets belonging to the village of $B a^{\prime} t a n$ in the Kesu' territory, to the east of the capital, Rantepao.

225 Tondon is a territory to the east of the capital, Rantepao. Batulobo' is a region in the Tondon territory.

226 Balusu is a territory in the north-east of the Rantepao country.

$227 \mathrm{Sa}^{\prime} d a n$ is a territory in the north of the Rantepao country. Bori' is a complex in the north of the Tikala territory.

$228 P a n l i$ is a village in the Bori' complex. Malakiri is a village in the Balusu territory.

229 Tallunlipu is a village in the south-east of the Tikala territory. Tagari is a village in the west of the Balusu territory.

230 Kandeapi is a hamlet belonging to the village of Barana' in the Tikala territory. Parindin is a village of the Bori' complex.

231 Tikala is a territory in the north of the Rantepao country. 
224 The God of the territory of the Paya' region, the Lord of the district of Sitodon.

225 The God of the territory of the Tondon region, the Lord of the district of Batulobo'.

226 The God of the territory of the Balusu region, the Lord of the district of Bonton.

227 The God of the territory of the $S a^{\prime} d a n$ region, the Lord of the district of Bori'.

228 The God of the territory of the Panli region, the Lord of the district of Malakiri.

229 The God of the territory of the Tallunlipu region, the Lord of the district of Tagari.

230 The God of the territory of the Kandeapi region, the Lord of the district of Parindin.

231 The God of the territory of the Barana' region, the Lord of the district of Tikala.

232 The God of the territory of the Batukamban region, the Lord of the district of Riu.

233 The God of the territory of the Pamabi' region, the Lord of the region of the River Salusule.

234 The God of the territory of the Lempo region, the Lord of the district of Akum.

235 The God of the territory of the Sesean region, the Lord of the district of Lindotau.

236 The God of the territory of the Buntukarua region, the Lord of the district of Pa'padanunan.

237 The God of the territory of Baruppu' region, the Lord of the district of Bettuan.

232 Batukamban is a village in the Riu complex of the Tikala territory.

233 Pamabi' is a village in the Riu complex.

Salusule is a river near the village of Pemanikan, in the Tikala territory.

234 Lempo is a village on the southerly declivity of Mt. Sesean; it belongs to the Bori' complex in the Tikala territory.

Akun is also a village of the Bori' complex; it is situated on the southerly declivity of Mt. Sesean.

235 Lindotau is a place on Mt. Sesean.

236 Buntukarua is a village in the Tikala territory.

$P a^{\prime}$ padanunan is a village in the Tikala territory; it is on the north-west declivity of Mt. Sesean.

237 Baruppu' is a complex in the north of the Panala' territory.

Bettuan is a territory in the west of the Rantepao country, adjoining the Mamasa territory. 
238 Deata lembanna padaß di Pazala', puanna padaß di Kattun.

239 Deata lembanna padan di Sereale, puanna padaß di Lolai.

240 Deata lembanna padan di Pemanikan, puanna padaß di Kondorzan.

241 Deata lembanna padan di Ba'lele, puazna padan di Panrante.

242 Deata lembanna padaß di Solo', puanna padar di Tampak.

243 Deata lembanna padan di Mariri, puanna padan di Maruaßz.

244 Deata lembanna padan di Sinki', puanna padaß di Pankalo' Puaß.

245 Deatanna padaz di Pao, puazna padan di Eranbatu.

246 Deata lembanna padaß di Kadundun. puazna padaß di Kanuruan.

247 Deata lembarna padaß di Salu, puazna padaz di Kalindunan.

248 Deata lembanna padaß di Sopai, puazna padan di Tazdirandan.

249 Deata lembanna padan di Piozan, puarna padaß di Napo.

250 Deata lembanna padaß di Laßzda, puanna padan di Madandan.

238 Panala' is a territory in the north-west of the Rantepao country.

Kattun is a village in the Lolai complex in the Payala' territory.

239 Sereale is a village in the west of the Tikala territory.

240 Pemanikan is a village in the south-west of the Tikala territory. Kondozan is a village in the south-west of the Tikala territory.

241 Ba'lele is a village in the Tikala territory, to the west of the capital, Rantepao.

241, 242, 243 Panrante, Solo', Tampak, Mariri and Maruan are all villages of the Nononan complex on the right bank of the River Sa'dan. Nononan was originally the name of the clan-house of Manaek, the daughter of Pabane' and Ambun diKesu'. Ambun diKesu' was a daughter of Puar riKesu', the heavenly being who descended onto the Kesu'.

244 Sinki' is a rock to the west of the capital, Rantepao.

Pankalo' Puan is another name for the Salusule River; the Pankalo' Puan region is in the neighbourhood of Pemanikan, in the Tikala territory.

245 The village of Pao lies to the south of the capital, Rantepao. Rantspao means $M a n g a$ Plain. Pao derives its name from the legendary manga tree planted there by Mendurana, a Prince of Bone. He tried to entice the woman of nobie birth, 
238 The God of the territory of the Payala' region, the Lord of the district of Kattun.

239 The God of the territory of the Sereale region, the Lord of the district of Lolai.

240 The God of the territory of the Pemanikan region, the Lord of the district of Kondonan.

241 The God of the territory of the Ba'lele region, the Lord of the district of Payrante.

242 The God of the territory of the Solo' region, the Lord of the district of Tampak.

243 The God of the territory of the Mariri region, the Lord of the district of Maruan.

244 The God of the territory of the Sinki' region, the Lord of the district of Pankalo' Puan.

245 The God of the territory of the Pao region, thiel Lord of the district of Eranbatu.

246 The God of the territory of the Kadundun region, the Lord of the district of Kanuruan.

247 The God of the territory of the Salu region, the Lord of the district of Kalinduman.

248 The God of the territory of the Sopai region, the Lord of the district of Tazdirandan.

249 The God of the territory of the Pionan region, the Lond of the district of Napo.

250 The God of the territory of the Landa region, the Lord of the district of Madandan.

Landorundun $=$ The One whose Hanging Hair Is Long, The woman with hair seven fathoms long, to eat the fruit of the tree, so that he could unite in marriage with her.

Eranbatu is a protruding rocky part of the River Sa'dan, near the village of Pao.

246 Kadundun and Kanuruan are villages in the Nononan complex, in the Kesu' territory.

247 Salu is the name of a group of three villages on the northern declivity of Mt. Sopai; this group is in the Nonozan complex.

Kalindunan is one of these three villages.

248 Mt. Sopai is in the south-west of the Rantepao country.

Taßdirandan is a place on Mt. Sopai.

249 Pionan is one of the territories in the west of the Rantepao country.

Mt. Napo is in the west of the Rantepao country. The heavenly ancestor of the clan-houses in the territories in the west of the Rantepao country, descended onto this mountain.

250 Madandan is a territory in the south of the Rantepao country.

Landa is a village in the Madandan territory. 
251 Deata lembanna padaß di Tina', puazna padan di Padaniriz.

252 Deata lembanna padan di Lambun, puazna padaß di Baßa.

253 Deata lembanna padan di Malimbon, puanna padaß di Ulusalu.

254 Deata lembanna padan di Massila, puanna padaß di Ledo.

255 Deata padan di Rampoanbaba', puanna padaß di Sapan Deata.

256 Deata lembaßna padaß di Sado'ko', puazna padaß di Sarapian.

257 Deata lembaßna padaß di Buakaju, puanna padaß di Rano.

258 Deata lembanna padaß di kalambunan allo, puanna padaß di kabotoan kulla'.

259 Deata lembanna padaß di Simbuaß, puaßna padaß di Bau.

260 Deata lembanna padan di Gasin, puanna padaß di Paßo-paßo.

261 Deata lembanna padan di Bankele, puaßna padaß di Gandanbatu.

262 Deata lembanna padan di Duri, puazna padaß di Malua'.

263 Deata lembaßna padaß di Bamba Puaß, puaßna padaß di Rura.

251 Tina', Padanirin and Lambun are villages in the Tapparan territory.

252/253 Bana and Malimbon are territories in the north-west of the Ma'kale country.

253 Ulusalu is a territory in the west of the Rantepao country, west of the Pionan territory.

254 Mt. Massila is in the north-west of the Ma'kale country. Ledo is a territory in the west of the Rantepao country.

255 Sapan Deata is a place in the River Sa'dan where Sandabilik, the wife of Tamborolani, the ancestor of the puary lineages who descended from heaven, rose from the river.

256 Mt. Sado'ko' is in the south-west of the Ma'kale country. Sarapian is a region on Mt. Sado'ko'.

257 Buakayu and Rano are territories in the south-west of the Ma'kale country, on the right and left bank of the River $S a^{\prime} d a n$, respectively.

259 Simbuan is a territory in the south-west of the Ma'kale country. In language and adat usages, it conforms to the territories of Tandalanan in the Mamasa country, which lie on the right bank of the River Masuppu'. 
251 The God of the territory of the Tina' region, the Lord of the district of Padanirim.

252 The God of the territory of the Lambun region, the Lord of the district of Baza.

253 The God of the territory of the Malimbon region, the Lord of the district of Ulusalu.

254 The God of the territory of the Massila region, the Lord of the district of Ledo.

255 The God of the territory of the Rampoanbaba' region, the Lord of the district of Sapan Deata.

256 The God of the territory of the Sado'ko' region, the Lord of the district of Sarapian.

257 The God of the territory of the Buakayu region, the Lord of the district of Rano.

258 The God of the region where the sun descends, the Lord of the region where the shining one sinks down.

259 The God of the territory of the Simbuan region, the Lord of the district of Bau.

260 The God of the territory of the Gasin region, the Lord of the district of Pano-pano.

261 The God of the territory of the Baykele region, the Lord of the district of Gandanbatu.

262 The God of the territory of the Duri region, the Lord of the district of Malua'.

263 The God of the territory of the Bamba Puan region, the Lord of the district of Rura.

260 Mt. Gasin is south of the capital, Ma'kale.

Paßo-pano is a village on the declivity of Mt. Gasin; it lies south of the capital, Ma'kale.

261 Bankele is the name of a group of villages belonging to the Gandambatu complex in the Menkendek territory.

262 Duri is the name of a community of three territories, namely, Alla', Malua' and Buntubatu belonging to the Masenrempulu' Federation, southward of the Ma'kale country.

263 Mt. Bamba Puan = "The Region of the Gods", is north of the capital, Enrekan. According to tradition, the "Land of Souls", Puya, of the South Toradja, is in the neighbourhood of this mountain. The souls of those for whom the full-dress death ritual is performed, climb from this mountain to heaven.

Rura = "Pool", is the name of a place where the ground has subsided, south of Kalosi, the result, according to tradition, of an incestuous marriage that was concluded there. All the participants at the feast perished as the ground subsided, except London diRura who was spared by Puan Matua. 
264 Deata lembanna padaß di Sinadi, puanna padaß di Se'ke'.

265 Deata lembanna padaß di Uluwai, puanna padaß di Simbuan.

266 Deata lembanna padaß di Batualu, puanna padaß di Tokesan.

267 Deata lembanna padaß di Marindin, puaß padaß di Menkendek.

268 Deata lembanna padaß di Sarimbano, puanna padaß di Banua Puan.

269 Deata lembanna padaß di Teßan, puanna padaß di Kandora.

270 Deata lembaßna padaß di Kaero.

271 Deata lembanna padaß di Daßle', puanna padan di Burake.

272 Deata lembanna padaß di Aa'kamban, puanna padaß di Ma'kale.

273 Deata lembanna padaß di Taronko, puazna padan di Bunin.

274 Deata lembanna padaß di Mendetek, puaßna padaß di Lion.

275 Deata lembanna padaß di Lemo, puaßna padaß di Sezßa'.

264 Sinadi, in the south-east of the Ma'kale country, is a spur of Mt. Latimodjon. $S e^{\prime} k e^{\prime}$ is a region in the Sayalla' territory.

265 Uluwai is a complex in the south-east of the Sanalla' territory. Simbuan is a complex in the Sayalla' territory, to the south of the Batualu complex. It is not to be confused with the Simbuan mentioned in note 259.

266 Batualu is a complex in the south-east of the Sayalla' territory. Tokesan is a complex in the Sanalla' territory.

267 Marindin is a village in the east of the Menkendek territory, in the Ma'kale country.

268 Sarimbano is a village in the west of the Gandaybatu complex, in the Menkendek territory.

Banua Puan is the clan-house in Marindin: it was founded by the son of London diRura, from whom the ancestors of the prominent lineages in all the territories of the $S a^{\prime} d a n$ region are descended.

269 Teman is a village in the Menkendek territory, where the oldest clan-house of the puan lineages of Menkendek was erected.

Kandora is a rock in the Ma'kale territory where the ancestor of the puan lineages of Sanalla', Ma'kale and Menkendek, called Tamborolami', descended. 
264 The God of the territory of the Sinadi region, the Lord of the district of $S e^{\prime} k e^{\prime}$.

265 The God of the territory of the Uluwai region, the Lord of the district of Simbuan.

266 The God of the territory of the Batualu region, the Lord of the district of Tokesan.

267 The God of the territory of the Marindin region, the Lord of the district of Menkendek.

268 The God of the territory of the Sarimbano region, the Lord of the district of Banua Puan.

269 The God of the territory of the Teman region, the Lord of the district of Kandora.

270 The God of the territory of the Kaero region.

271 The God of the territory of the Danle' region, the Lord of the district of Burake.

272 The God of the territory of the Aa'kamban region, the Lord of the district of Ma'kale.

273 The God of the territory of the Taronko region, the Lord of the district of Bunin.

274 The God of the territory of the Mendetek region, the Lord of the district of Lion.

275 The God of the territory of the Lemo region, the Lord of the district of Sezma'.

These three small kingdoms, governed by a puaß, are called collectively Tallu lembanna $=$ The Three States.

270 Mt. Kaero is in the Sanalla' territory: the mother-clan house of the puan of Sanalla' was erected there.

271 Mt. Damle' is in the Ma'kale territory.

Burake is a village to the north of the capital, Ma'kale.

272 Aa'kamban is a village to the south of the capital, Ma'kale.

Ma'kale is the capital of the Tana Toradja, the whole area inhabited by the Sa'dan Toradja.

273 Taronko is a village in the north of the Ma'kale territory.

Bunin is a complex in the north of the Ma'kale territory.

274 Mendetek is a complex in the north of the Ma'kale territory.

Lion is a village in the above mentioned Mendetek complex.

275 Lemo is a complex in the north of the Makale territory.

Senza' is a settlement belonging to the village of Limbu, in the north of the Ma'kale territory. 
276 Deata lembanna padaß di Bebo', puanna padan di Bokko.

277 Deata lembaßna padaß di Bubusan, puanna padaß di Taßmembase.

278 Deata lembanna padaß di Rorre, puaßna padaß di Tilaßza'.

279 Deata lembanna padaß di Limbu, puazna padan di Pani.

280 Deata lembaßna padaß di Tadonkon, puanna padan di Taraneze.

281 Deata lembanna padaß di Saßbua', puanna padaß di Tallutollo'.

282 Deata lembanna padaß di To' Kamiri, puanna padaß di To' Kalimbuaß.

283 Silelemokomi deata kapadaranna kupalilin kanan kukambio santuß, upu'mokomi puaß kapajan-pajananna kutamben bala tedon kuko'bi' riti bulaan.

$284 \mathrm{~Pa}$ denkomi manii nasalapa te randan dipudukku, denkomi manii nalendapa te dara' lezko lilaku.

285 Apa silelemokomi kutamben bala tedor kukambio santuß.

286 Deata iKesu'mo randan to mamma' sitamban sandeatanna, Puaß di Beloara'mo biriß to matindo sikorok londoß saßkapuaßanna.

287 Garagamokomi sanda silili' deata kapadananna, tampamokomi sanda sigontin puan kapajan-pajananna.

288 Garagakomi saßke'deran, tampakomi saßtiaßkaran.

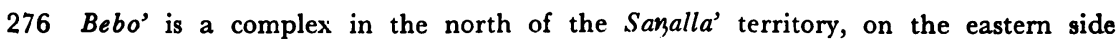
of the Sarira rocks.

Bokko is a village in the north of the Sanalla' territory.

277 Bubusan is a village in the south-east of the Kesu' territory, to the west of the Sarira rocks.

278 Rorre is a village belonging to the Mendetek complex, in the north of the Ma'kale territory.

Tilanya' is a settlement belonging to the village of Limbu, in the north of the Ma'kale territory.

$279 P a n i$ is a settlement belonging to the village of Limbu.

280 Tadonkon is a village in the south of the Kesu' territory.

281 Sarbua' is a village in the south of the Kesu' territory.

At present it belongs, with Tadonkon and Anin-azin, to the Tallutolo community. Tallutolo' is the name of the most prominent clan-house of Sanbua' of which the puan of Ma'kale is also a member.

$282 T^{\prime} o^{\prime}$ Kamiri $=$ The place of the Kemiri tree (Aleurites moluccana), is the name 
276 The God of the territory of the Bebo' region, the Lord of the district of Bokko.

277 The God of the territory of the Bubusan region, the Lord of the district of Tanmembase.

278 The God of the territory of the Rorre region, the Lord of the district of Tilanna'.

279 The God of the territory of the Limbu region, the Lord of the district of Pani.

280 The God of the territory of the Tadonkon region, the Lond of the district of Taranene.

281 The God of the territory of the Sambua' region, the Lord of the district of Tallutollo'.

282 The God of the territory of the To' Kamiri region, the Lord of the district of To' Kalimbuan.

283 Round thee have I gone from the right, gods of the earth, fingering the strumming instrument, summoning thee,

now I have come to the end of calling thee, gods of the visible world, plucking the golden strings, from low unto high.

284 Perchance there are some of thee whom the tips of my lips have forgotten to mention,

mayhap there are some among thee who have been overlooked in the words I have spoken, in their regular order.

285 But I have summoned all of thee, fingering the strumming instrument, from low unto high.

286 Wilt thou then, God of the Kesu', as the first in the row of the sleeping ones, call thy co-gods, from here and from there?

Wilt thou, Lord of Beloara', as the foremost of the slumbering ones who, with thee, are revered as lords, make heard the summons to and fro, as the cock calls the hens?

287 Form now, gods of the earth, a gathering consisting of all of thee, bring about a meeting, lords of the visible world, in which all are included.

288 Arrange a complete start,

form a united departure.

of a sawah where Polopadan, the son of Pabane' and Ambun diKesu', "The Morning Mist of the Kesu' ', the daughter of the heavenly being, Puan riKesu', who descended onto the Kesu', wedged himself between the stones of the sheetpile of the fish pond when he took fish out of it. His sister, Manaek, went to help him and released his hand by striking it with her jacket.

To' Kalimbuan, "the place of the spring", is the parallel of To' Kamiri. 
289 Misipadolo-dolomi, sipataß̋a-taßßаmi, sipaundi-undimmi.

290 Apa da mima'kambelaß-belaß, da mima'bantala-tala.

291 Pamagasai to' talinammi, paturukki lamba' beluakmi.

292 Lendu'komi ala roßko'na Duabontik lan di Duri, kala'pakomi batu lappa'na Tallutoponna lan di Malua'.

293 Alakomi roßko'na pekapuazan lan di Sazalla', kala'pakomi batu lappa'na to kabarre-alloan lan di Ma'kale.

294 Alakomi roßko'na Tutu'baka lan di Buntao', kala'pai batu lappa'na Kajok lan di Umakalua'.

295 Alakomi roßko'na Tandukminna' lan di Pantilaß, kala'pakomi batu lappa'na Pundusarai lan di Sumalu.

296 Alakomi roßko'na Batulobo' lan di Tondon, kala'pai batu lappa'na.

297 Alakomi roßko'na Matabulaan lan di Kondozan, kala'pai batu lappa'na.

298 Alakomi ronko'na Bakasiroe lan di Madandan, kala'pai batu lappa'na.

299 Alakomi roßko'na Tannuntaßmaßka lan di Nonoßan, kala'pai batu lappa'na.

292 The Duabontik is a fighting weapon with pointed ends. It has magical power; bontik = pointed end. The Duabontik was the pusaka-object allotted to Lai' Bue, the daughter of Tandilino' and Buenmanik. Tandilino' was the descendant of London diRura, the ancestor who evaded the destruction wrought at the feast place in Rura, see strophe 263.

batu lappa': the scale on the foot of a fighting cock; its presence presages prosperity.

The Tallutoponna is a fighting weapon with three broad points; topon = broad end. The Tallutoponna is the parallel of the Duabontik.

For Malua', see str. 262.

293 For Sanalla', see str. 269.

For Ma'kale, see str. 269. The Illustrious One in $M a^{3} k a l e$, is the puan of the $M a^{\prime}$ kale territory. Pekapuanan $=$ he who is addressed as puan.

kabarre-alloan = illumined by the shining disc of the sun.

294 Tutu'baka is the name of a carrying basket with a lid on it. It was the pusakaobject allotted to Paraze, the brother of Lai' Bue.

The Kayok is a sword with magical power.

Umakalua' is a village in the Buntao' territory, in the south-east of the Rantepao country. 
289 Let the ones who stand in the front go together and lead the way, let the ones in the middle go together, and the ones at the end go together.

290 But thou shalt not go empty-handed, thou shalt not be without anything.

291 Make heavy that which rests above thine ears, let it make tangled the hair of thy head.

292 Call to Duri and dig up the good fortune of the Duabontik, unearth the prosperity of the Tallutoponna in Malua'.

293 Bring the good fortune of the ones who are called puan in Sanalla', take hold of the prosperity of the illustrious ones in $M a^{\prime}$ kale.

294 Bring the good fortune of the Tutu'baka in Buntao', take hold of the prosperity of the Kayok in Umakalua'.

295 Bring the good fortune of the Tandukminna' in Pantilan, take hold of the prosperity of the Pundusarai in Sumalu.

296 Bring the good fortune of the Batulobo' in Tondon, take hold of the prosperity thereof.

297 Bring the good fortune of the Matabulaan in Kondonan. take hold of the prosperity thereof.

298 Bring the good fortune of the Bakasiro-e in Madandan, take hold of the prosperity thereof.

299 Bring the good fortune of the Tannuntanmanka in Nononan, take hold of the prosperity thereof.

thou art the lord great of compassion.

295 I have not been able to get an explanation of Tandukminna'.

Pundusarai is the name of a small stone shaped like a buffalo; it has a powerful magic.

$296 B^{B}$ atulobo' $=$ Stone that swells of its own accord; it exerts a powerful influence on the increasing of prosperity.

297 Matabulaan = sword with a gold blade; it is the name of a sword with powerful magic. It originated with Manaek, the daughter of Puan riKesu', the heavenly being who descended onto Mt. Kesu'.

298 Bakasiro-e = The two carrying baskets attached to each other. It is the name of a pusaka-object in the Madandan territory. It was taken by Karasiak from the people of Bone in the war against Arum Palakka, the leader of the people of Madandan. Karasiak took part in the revolt of the chiefs of Sa'dan who fought against Bone. His weapon was a lance, called Dokepedullu $=$ The lance that points at; anyone at whom it pointed, died.

299 Tannuntanmanka $=$ The unfinished weaving; it is the name of a piece of tjindai cloth. It was woven by Manaek while she was sitting on a hill called Nonozan, on a loom that stood on Mt. Kesu' and which spanned the Sa'dan river. Manaek married Puan Tambulibuntu, a grandson of Tamborolani', the ancestor of the puan lineages. 
300 Apa kamumo deata mamase, kamumo puaß sa'pala buda. ${ }^{\text {b) }}$

304 Pokinallo ilalankomi bai makianakan, pobokon dilambanankomi doko umpatale' anak.

305 Pokinallo ilalankomi bujanna manuk, pobokon dilambanankomi kanuku diarru'.

306 Pokinallo ilalankomi sarita to lamban, pobokon dilambanankomi maa' to unnoron.

307 Pokinallo ilalankomi gajaß ditarapani, pobokon dilambanankomi kandaure salombe'.

308 Mintu' ianan sanda rupanna, makalima'na baraß apa mintu' sola nasaß.

309 Tindo maelo, mamma' makatozan-toran.

310 Lindo masakke, rupa madarindin, mendaun sugi', mentaßke ianan.

311 Mintu' to la napoinaa, makalima'na to la napoba'ter.

312 Apa da milempan to minda-to minda, da mima'lalan tau sena'.

313 La rampo lembaßkomi indete tizo banuanna to ma'rapu tallaß, la tu'tun koli-kolikomi inde paßrante manikna to ma'kaponan ao'.

314 La tonkonmokomi dao sendana sugi', ma'pazan-paßan sitammu saßdeatammi titanan tallu.

315 Unnesußmokomi dao kaju mentanke ianan, ma'damerak-merak sirompa' saßkapuanammi samba' batu lalikan.

b) Strophes 301, 302 and 303 are similar to strophes 104, 105 and 106 of B, and are therefore not included.

311 The "their" and the "they", mean the gods.

314 sandeatammi titanan tallu $=$ thy co-gods consisting of a group of three; group of three means the gods of the upper world, of this world and of the underworld. 
300 For thou art the merciful god, thou art the lord great of compassion.

304 As sustenance for the journey, take the sow, which farrows plentifully, as provisions on the way, take the swine that drop young, which roam far and wide.

305 As sustenance for the journey, take the fowls, sitting on their perches, as provisions on the way, take the claws that are trimmed with a small knife.

306 As sustenance for the journey, take the old long narrow blue woven cloth with the design of men fording a river,

as provisions on the way, take the old short wide fabric with the pattern of swimming men.

307 As sustenance for the journey, take the gold kris of great size, as provisions on the way, take the piece of beadwork with the cords hanging low.

308 All the goods of all kinds, all the possessions together.

309 An auspicious dream, a pregnant nocturnal vision.

310 A countenance full of goodwill, a benevolent appearance, riches in quantity, like foliage; precious things, like the branches of the tree.

311 Everything that will be in their thoughts, all the things of which they are mindful.

312 And thou shalt not branch off onto the one way or the other, thou shalt not take the path of other people.

313 So that thou arrivest here, at the forecourt of the house of the clan members, numerous as bamboo culms, like the coming of a prau, in order that thou comest here, to the court which shines like beads, of the ones whose group always increases like a bamboo stool, like a small boat bumping [against the landing stage].

314 Then shalt thou take thy seat on the richly laden tjendana tree, and meet thy co-gods, consisting of a group of three, while chewing the betel quid,

315 Then shalt thou sit down on the tree whose branches are full of precious things, together with the ones who, with thee, are revered as lords, in a group of three, like the stones of the hearth, whilst making thy mouths red. 
316 Ammi bolloan barra'i rokko rianna to ma'rapu tallaß, ianan sanda rupanna sola lindo masakke.

317 Ammi baku amboranni rokko sulenka rara'na te to ma'limbo kaluku, baraß apa mintu' sola nasaß sola rupa madarindin.

318 Apa la sulepa' te maßkali oto', la tibalikpa' te ma'ponka parompon.

319 Apa ia ade' tonna silopakpa lani' tana kalua', pusa'pa ade' saßga mairi', ia ade' tonna sikandepa to palulluzan lipu daenan, kalilipa ade' mintu' sola nasaß.

320 Taß pajanpa rante kalua', taß sombopa pa'buntu-batuan, taß tibori'pa paßkalo' puaß.

321 Apa sisarak ade' lani' tana kalua', simanta mambela ade' lipu daenan to palullußan.

322 Pajanmo ade' rante kalua', tibori'mo ade' paßkalo' puaß.

323 Dadimo ade' anakna lani', anakna tana kalua' titanan tallu, takkomi ade' kamaseanna to paoßanan, lipu daenan samba' batu lalikan.

324 Kasalle dadinna anakna lani', anakna tana titanan tallu, lobo' garaganna bonsunna to paozanan, lipu daenan samba' batu lalikan.

325 Disanami Poß Tulakpadaß, disaßami Poß Baßgairante, disanami Gauntikembon.

326 Umbalianammi batu ba'taßna titanan tallu, umbibi'mi karaßan pasiruanna samba' batu lalikan.

327 Upu'mi ma'taßßa'-taßßa' titanan tallu, sundunmi ma'inaa-naa samba' batu lalikan.

319 lipu in lipu daenan, means village in Bare'e, the language of the East Toradja. In the poetical language of the South Toradja, lipu daenan is the word for dwelling area. The word lipu also occurs in the place-name, Tallunlipu, in the Rantepao country, which means the three hamlets.

320 pankalo' puan = channels in the fields dug by the lords; it is the poetical description of the ricefields. The term owes its origin to the prototype of the wet ricefield, i.e., the ricefield dug by the gods in heaven. In strophe 352 , the term has the meaning of great river.

323 takko: already robust and strong enough to perform all kinds of work; here it is the parallel of dadi= to come into the world. The shade of meaning between the two terms is that takko means to come into the world healthy and strong.

325 Pon Tulakpadan = Lord who Supports the Earth.

bangai = tall; said of thin things. In the Bare'e language the word is banke. Pon Bangairante = Lord Whose Plain is Large; he is the god of the earth. 
316 Then, as men scatter rice, onto the laps of the clan members, numerous as bamboo culms, pour forth all kinds of precious things, with a benevolent countenance.

317 Then, as men cast seed, onto the splendidly crossed legs of the ones who are gathered together here, like coconut palms, let fall all sorts of possessions, with a beneficial aspect.

318 But now shall I again return to unearth what was at the start, now I shall again turn to dig up what was at the beginning.

319 At that time when, so we are told, heaven and the broad earth still lay on each other, all was chaos, then, so it is said, the all-enfolding still touched the regions of the earth, all was still in disorder.

320 The wide flat land was still invisible, clusters of rocks were still not to be seen, the channels in the fields, dug by the lords, were not visible.

321 Then, so we are told, heaven and the broad earth separated, the earthly regions and the all-enfolding divided.

322 And, so it is said, the wide flat land was visible, the channels in the fields, dug by the londs, could be seen.

323 Then, so it is said, the children of heaven and of the wide earth were born, forming a trinity,

then came into the world the gifts of the union of the all-covering roof, and the earthly regions, well-shaped, the three who were as the stones of the hearth.

324 Then the children of heaven and earth, forming a trinity, grew up, then the offspring of the all-covering roof and the earthly regions, the three who were as the stones of the hearth, reached maturity and developed fully.

325 They were then given their names, Pon Tulakpadan, Pon Bangairante and Gauntikembon.

326 Then the ones who form a trinity, brought their innermost being into movement,

thereon, the trinity, together like the stones of the hearth, brought the kernel of their inwardness into action.

327 The ones who form a trinity were at the end of their consultations, the ones who are a trinity, together like the stones of the hearth, concluded their deliberations.

Gauntikembon = Self-Expanding Cloud; he is one of the gods of the upper world, see introduction to B, p. 12 and 13 . 
328 Ungaragami ade' liku lambe'na kombon kalua' titanan tallu, untampami ade' tinimbo malambe' samba' batu lalikan.

329 Ungaragami ade' allo, ußkomboß arraß sama lele.

330 Ungaragami bulan, ußkombon sulo taroßko malillin.

331 Ungaragami ade' bintoen tasak, ußkombon asi-asi dannari.

332 Napaunnolami ade' manete rara'na lani' allo, namasiaß lan kapadazanna, napopa'lalanmi ade' pata' bulaanna to palullußan arraß sama lele, anna masero lan kapajan-pajananna.

333 Napaunnolami taß̧ana lani' bulan, anna masiaß lan taßßana boßi.

334 Napopa'lalanmi sisamanna to palulluzan bintoen tasak, namasero lan paseko malillin.

335 Ma'kadami Poß Tulakpadaß kumua: La malemo' aku rokko maririnna litak, la dionmo' maßapi'na tana.

336 Anna den nakamalizi to sanda raßka'na, aku ußkalampi'i tanan-tanananna.

337 ke tae' nasiria penkalosoran manaku kumba', ke tae' nasisaladan saßka' peßkalaoan maßore tanda darandaß.

328 lambe'na kombon kalua': the size of an extended plantation.

330 "the torch of the large dark stone", is the parallel expression for the moon.

332 manete is a form, no longer used in the common language, of tete $=$ bridge; untete $=$ to go over a bridge. kapayan-payananna $=$ visible.

337 nasiria $=$ nasisaladan $=$ they hold each other on the lap, they cherish each other. manaku $k u m b a^{\prime}=$ to confess guilt with a heart weak as the pith of the main leaf rib of the high palm with the ringed horny trunk (Oncosperma filamentosum B1.), the nibun palm, a high palm with a ringed horny trunk; it has small fruit 
328 Then, the ones who form a trinity, so we are told, created an extensive numerous community,

then, so it is said, the ones who are a trinity, together like the stones of the hearth, brought into being a great host.

329 It is said that they fashioned the sun, that they created the light that shines everywhere.

330 They fashioned the moon, they created the torch of the large dark stone.

331 They fashioned, so we are told, the yellow-shining stars, they created, so it is said, the constellations of the late part of the night.

332 They let the sun, so we are told, travel along the brilliant centre line of the firmament, then there was light on earth,

they caused, so it is said, the light that shines, round, to go along the golden middle line of the all-enfolding, and then there was brightness in the open fields.

333 They caused the moon to have her course in the centre of the sky, then there was light in the middle of the night.

334 They let the yellow-shining stars take their courses exactly in the middle of the all-enfolding,

then there was light in the outer layer of the darkness.

335 Then said Pon Tulakpadaß:

"I shall now go downwards, to the layers below the earth,

I shall now take up my abode in the levels of the earth lying on each other."

336 "When the ones whose limbs are complete transgress,

then shall I tear out what they have cultivated."

337 "If they will not truly be bound by the rites of the atonement offering, and confess their guilt,

if they will not be closely associated with the ritual of the expiatory sacrifice, repenting, with the heart weak as the kapok on the rib of the leaf of the high palm with the ringed horny trunk."

manore tanda darandan $=$ to cease to do wrong with a heart weak as the plug of blood-smeared kapok; this is used at the expiatory ritual: darandan $=$ bloodsmeared kapok; this is stuck on a leaf rib; tanda tinaran = like the small arrow of the blow pipe; a plug of the pith of the main rib of the leaf of the palm (Oncosperma filamentosum Bl.) is attached to the end of the arrow. Tanda tinaran is used often instead of tanda darandan. 
338 Lanmi ade' kapadaßanna Poß Baßgairante, sirampanan kapa' Tallo' maßka kalena, sipakuleasan pa'sullean allo Datu baine.

339 Dadimi ade' buanna rampanan kapa' sanda karua, takkomi kamaseanna pa'sullean allo ganna' bilazanna.

340 Kasalle dadinna to sanda karua, lobo' garaganna to ganna' bilananna, pada umposaza sazanna, pada umpoganti pa'gantiananna.

341 Disazami ade' Saripibulaan, diganti Datu muane.

342 Disanami ade' Puan Radeß, diganti Datu muane.

343 Disanami ade' Timbajokila', diganti Datu muane.

344 Disanami ade' Poß Tulaßdenna, diganti Datu muane.

345 Disaßami Tandiminaza, diganti Datu muane.

346 Disaßmi Poß Lalondon, diganti Datu muane.

347 Disanami Indo' Pare'-pare', diganti Datu baine.

348 Disßami Indo' Samadenna, diganti Datu baine.

349 Malemi ade' lako randanna laßi' Saripibulaan.

338 sirampanan $k a p a^{\prime}=$ to conclude an agreement to marry.

Figuratively, the term means to make the reciprocal decisions regarding the $k a p a$. These decisions are made by the parties of the spouses concerned. The $k a p a^{\prime}$ is the penalty to be paid by the one who breaks up a marriage and is often assessed when the spouses have been married for some time.

Tallo' Manke Kalena = Egg That Had Come Into Being of Itself.

sipakuleasan $=$ to transport by swimming.

pa'sullean allo $=$ the changing of the activities of the day; it is a poetical expression for marriage.

Datu Baine $=$ Goddess.

Dat $u=$ God, spirit, prince. Datu often occurs in Sa'danese proper names: for example, Lai' Datu Lani' = Princess of the Firmament; Pata' Datu= Royal Lengthwise Beam.

puan also means God, spirit, lord.

341 Datu Muane = God.

342 Puan Raden = Lord Who Leans Sitting Against Something.

344 Pon Tulaydenna $=$ Lord Who Stays in a Definite Place. He dwells on Mt. Sopai, in the Rantepao country, and in the Sa'dan river flowing below it. He carries 
338 Pon Bangairante, so it is said, established himself on earth and concluded a marriage with Tallo' Manka Kalena,

he entered into a union with Datu Baine.

339 Then the fruits of the marriage were born, all eight of them, thereon came into the world the gifts of the union, well-shaped, complete in number.

340 All eight of them reached maturity, their forms developed fully, each of them had a name, and each of them received another name as well.

341 He was called, so we are told, Saripibulaan, and his other name was Datu Muane.

$342 \mathrm{He}$ was called, so we are told, Puan Raden, and his other name was Datu Muane.

343 He was callad, so we are told, Timbayokila', and his other name was Datu Muane.

344 He was called, so we are told, Pon Tulandenna, and his other name was Datu Muane.

345 He was called Tandiminana, and his other name was Datu Muane.

346 He was called Pon Lalondon, and his other name was Datu Muane.

347 She was called Indo' Pare'-pare', and her other name was Datu Baine.

348 She was called Indo' Samadenna, and her other name was Datu Baine.

349 Saripibulaan, so we are told, went to the edge of the sky.

off people who de not offer him a gift when they want to cross the river.

345 Tandiminana $=$ The Support of the River Mouth; he is the god who dwells in the sea.

346 Pon Lalondon: the judge in the Land of the Souls; he passes judgement on the souls of deceased persons and can refuse them entry into the Land of the Souls.

347 The word indo' $=$ mother, of ten precedes the names of married women. Indo' Pare'-pare' $=$ Mother Small Kind of Rice.

348 Indo' Sadenna $=$ Mother Everything Is in Hand. Indo' Sadenna = Indo' Samadenna; Samadenna is probably an um-form of Sadenna. Sadenna is the name a little girl, called Tulandidi', was given when she ascended to the moon. She had been killed by her father and was brought back to life by the cock she had with her. See Verhandelingen Bataviaasch Genootschap van Kunsten en Wetenschappen. Vol. LXV, 2nd part, pp. 63-70. Compare strophes 65-68. There are apparently two stories in circulation about these characters. 
350 Malemi ade' lako tetukna lani' Puaß Radeß.

351 Malemi ade' tama batu Timbajokila', lanmi kumila' kalle-kallean Datu muane.

352 Malemi ade' rokko pankalo' puaß Poß Tulandenna.

353 Malemi Tandiminana tama tasik kalua', lanmi bomban malolazan.

354 Naden nakamalini to sanda raßka'na, natae' namamma' rokko rianna pezkalossoran maßaku kumba', aku pabaßun ada' umbalianan lembaß lan tasik.

355 Nakuami Pon Lalondoß: La malemo' tama Puja, anku peotini to mempuru' lampak.

356 Ussialaimi ade' unuran bulaan Indo' Pare'-pare', Indo' Samadenna, namallai tama allo Indo' Pare'-pare', namallai tama bulan Indo' Samadenna.

357 Malemi ade' Gauntikembon laßß̧an taßßana laßi', umpokaa' ambe' to kumombozna,

malemi ade' Datu muane laßßzan masuangana to palullußan, umpanlola baan to mendadianna.

358 Sazbua bannaßmi ade' lan taß̧ana lani' Gauntikemboß, sankaju lolimi lan masuangana to palullunan Datu muane.

359 Umbaliaßammi ade' batu ba'tanna lan taß̧̧ana lani', umbibi'mi karaßan pasiruanna lan masuaßgana to palullußan.

360 Umpatuka'mi pa'ba'taßan, umpasolo' pa'inaan.

352 "the channel in the fields dug by the lords", must here mean a large river, see str. 320 .

$355 P u y a=$ Land of the Souls; it is situated in the south of the Toradja country in the neighbourhood of Mt. Bamba Puan (The Place of the Gods) between Kalosi and Enrekan.

According to tradition, the Sa'dan Toradja migrated from the south to their present dwelling area. In olden times, the stair connecting earth and heaven stood by Mt. Bamba Puan.

umpeotini $=$ to cut off ; otin $=$ the extreme point of a sword.

ullampak $=$ to cut of $\dot{f}$; lampak $=$ the allotted span of life, the duration of one's life.

358 sambua bannan $=$ a single thread; this expression indicates that Gauntikembon was unmarried.

sankayu loli: a single piece of wood around which kapok or cotton has been wrapped; loli: cotton or kapok which has been wrapped round a piece of wood in order to spin the thread. 
350 Puan Radem, so it is said, went to the rim of the sky.

351 Timbayokila', so we are told, went inside a stone.

Datu Muane was then in the miraculous rock.

352 Pon Tulaydenna, so we are told, went downwards to the channels in the fields, dug by the lords.

353 Tandiminaza entered the wide sea, and dwelt then among the heaving waves.

354 "When the ones whose limbs are complete transgress, and if they do not lay themselves on the lap of the atonement offering, and confess their guilt,

then, indeed, am I the one who applies the Rule and capsizes the vessel."

355 And Poß Lalondoy said:

"I will enter the Land of the Souls, in order to cut short the lives of those whose span of life is near its end."

356 Indo' Pare'-pare' and Indo' Samadenna, so we are told, each tried to snatch from the other the golden spinning wheel,

then Indo' Pare'-pare' fled into the sun, and Indo' Samedenna took refuge in the moon.

357 Gauntikembon, so we are told, ascended to the centre of the firmament, in order to reach his father who begat him.

Datu Muane, so it is said, went upward to the zenith of the allenfolding, searching diligently, as one hunts a parakeet, for the one who procreated him.

358 Gauntikembon was a man who stood alone in the centre of the firmament,

Datu Muane was a solitary one in the zenith of the all-enfolding.

359 Then, so we are told, he brought his innermost being into movement in the centre of the firmament,

thereon, he brought the kernel of his inwardness into action in the zenith of the all-enfolding.

360 Then he caused thoughts to arise, thereon he made the reflections sink down.

359 batu $b a^{\prime} t a n=$ the stone of his innermost being. karanan pasiruanna $=$ the alluvial gravel of his spiritual state.

360 "Then he caused thoughts to arise", "thereon he made the reflections to sink down", mean to deliberate at great length. 
361 Umpatiaßka'mi ade' bate lentekna lan taßßana laßi' undaka' saßdeatanna la narampanni kapa',

umpatirimbami ade' pesoenanna lu rokko lu tama kadellekan allo untuntun saßkapuaß̧anna la napakulea'i pa'sullean allo.

362 Apa tae' ade' sandeatanna natiro lindo la narampanni kapa', taß den ade' saßkapuaßzanna natontoni rupa kalua' la napakulea'j pa'sullean allo.

363 Sulemi ade' ma'inaa-naa, tibalikmi ade' ma'taß̧a'-taßna'.

364 Unnalami ade' usuk pandakna, nakombon to sanda karua, ussintakkimi ade' buku taß palambi'na, naombo' to pantan tarunona.

365 Kasallemi ombo'na, lobo'mi garaganna, umposaßami saßanna, umpogantimi pa'gantiananna.

Disanami Usuk sazbamban.

366 Umpatuka'mi pa'ba'taßan Usuk saßjbamban lan ba'taßna lazi', umpasolo'mi ade' pa'inaan Datu muane lan masuangana.

367 Tipandaju-dajumi ade' lu rokko lu tama undaka' saßdeatanna la narampanni kapa', tipandiu-diumi lan masuangana to paozanan lu rekke lu sau' untuntun saßkapuaßanna la napakulea'i pa'sullean allo.

368 Tae'mi ade' saßdeatanna natiro lindo, taß den ade' saßkapuananna natontoni rupa kalua'.

369 Pusa'mi batu ba'taßna, kalilimi karanan inaanna.

370 Umpatuka'mi ade' pa'ba'tanan Usuk saß̧bamban, umpasolo'mi ade' pa'inaan Datu muane.

361 bate lentekna $=$ his manner of going; bate lentek originally meant footprints.

362 saydeatanna $=$ his co-god. rupa $=$ form, shape, colour, external appearance.

366 Usuk Sanbamban = The One Special Rib; bamban = to protrude above something; with $u s u k=\mathrm{rib}$ it is the classifying numeral; sambamban $=$ a protruding piece. 
361 He rose to his feet in the centre of the firmament, seeking the one who, like himself was a deity, in order to conclude a marriage with her,

he swung his arms, so we are told, westwards and towards the place where the shining one ascends, trying to find the one who, as he did, bore the title of lord, so that he could enter into a union with her.

362 But, so we are told, he could catch no sight of the face of anyone who, like himself, was a deity, in order to conclude a marriage with her, there was no one, so it is said, who, as he did, bore the title of lord, whose countenance he could behold, so that he could enter into a union with her.

363 He returned, so we are told, meditating all the time, he went back, so it is said, reflecting continually.

364 He took out his floating rib, so we are told, and then there came into being the one whose limbs are complete,

he plucked out his not completely connected bone, and thereupon he gave life to the one whose members are entire.

365 His appearance was stalwart, his form was well-developed, he had his name, and he received his other name, he was called Usuk Saybamban.

366 Usuk Saybamban then caused thoughts to arise in the centre of the firmament,

Datu Muane, so we are told, then made the reflections in the highest part, sink down.

367 Then, so we are told, he went hither and thither, now westwards, now eastwards, seeking the one who, like himself, was a deity, in order to conclude a marriage with her,

he moved about in the highest part of the all-covering roof, to the North and to the South, trying to find the one who, as he did, bore the title of lord, so that he could enter into a union with her.

368 But, so we are told, he could catch no sight of the face of anyone who, like himself, was a deity,

there was no one, so it is said, who, like himself bore the title of lord, whose countenance he could behold.

369 Then he was bewildered in his innermost being, the kernel of his inwardness was confused.

370 Usuk Sambamban, so we are told, caused thoughts to arise, Datu Muane, so it is said, made the reflections sink down. 
371 Umpatianka'mi ade' bate lentekna sumalon-maloß tama rampe matallo, umpatirimbami ade' passoenanna lumizka-minka tama kadellekan kulla'.

372 Urraßimi ade' Simboloß manik metaa mammi' lan batu lauluß, untandin talinami ade' Lokkon loerara' melale' sanda marasa lanmai kumila' kalle-kallean.

373 Randukmi ade' Usuk saßbamban membo'bok tama batu lauluß, tipamulami ade' Puaß Bassi-bassian menniso burinda tama kumila' kalle-kallean.

374 Sinkali' ade' tae' natiro lindo Simbolon manik lan batu lauluß, taß denmi ade' natontoßi rupa kalua' Lokkon loerara' lan kumila' kalle-kallean.

375 Sulemi ade' umparra uai mata budanna Usuk sazbamban, Tibalikmi ade' Puaß Bassi-bassian ussebokan sakke malinona,

376 kumua: Lilinna' te buntu bojo' membo'bok tama batu lauluß, natae' kutiro lindo Simbolon manik, tikuna' te tanete malupu' mennisso burinda tama kumila' kalle-kallean, nataß den Lokkon loerara' kutontoni rupa kalua'.

377 Apa bulo saßlampa ade' Simbolon manik lan batu lauluß, tallaß taß kelesoan ade' Lokkon loerara' lan kumila' kalle-kallean.

378 Ma'kada toßanmi Simbolon manik lan batu lauluß, ma'tundu malesomi Lokkon loerara' lan kumila' kalle-kallean.

379 Bulo saßlampami Simbolon manik lan batu lauluß, tallaß taß kelesoan Lokkon loerara' lan kumila' kalle-kallean.

372 untandin talina is the parallel of urrani $=$ to hear; to incline the ears. kumila' $=$ steep hanging wall of rock.

373 menniso burinda is a qualitative compound of which the literal translation is: to bore like a grindstone. menniso is a variant of merriso.

375 umparra uai mata budanna $=$ he squeezed his many tears.

378 ma'tundu is used here instead of ma'tiundu: it is an unusual form of tiundu= to nod assent.

380 ban $u^{\prime}=$ positively; literally, as hard as the heartwood of a tree. tankean suru' $=$ the act of bringing an offering after confessing to a transgression; $s u r u^{\prime}=$ comb; figuratively, it means cleansing offering.

$t a^{\prime}$ gulinan $=$ path on which one goes to and fro.

ammi pabotta'na, I could not get an explanation of this word; the expression is 
371 Then, so we are told, he rose to his feet and went towards the East, he swung his arms, so it is said, in the direction where the shining one ascends.

372 Then, so we are told, he heard the charming laughter of Simbolon Manik coming out of the stone of basalt, he caught, so it is said, the sound of the most sweet laughter of Lokkon Lo-erara' emanating from the miraculous rock.

373 Usuk Sambamban, so we are told, began to make an opening in the stone of basalt,

Puan Bassi-bassian, so it is said, started to bore like a revolving grindstone into the miraculous rock.

374 Then, so we are told, he did not see the face of Simbolon Manik in the stone of basalt,

he did not, so it is said, catch sight of the countenance of Lokkon Lo-erara' in the miraculous rock.

375 Then, so we are told, Usuk Sambamban returned, his tears flowing profusely,

thereupon, so it is said, Puan Bassi-bassian, went back, shedding his clear liquid, and he said:

376 "I have walked round that mountain, weary of making an opening in the stone of basalt, and I did not see the face of Simbolon Manik,

I have paced round that hill, exhausted by boring like a revolving grindstone into the miraculous rock, and I did not catch sight of the countenance of Lokkon Lo-erara."

377 Now, so we are told, Simbolon Manik in the stone of basalt was upright,

Lokkon Lo-erara' in the miraculous rock was true of heart.

378 Simbolon Manik in the stone of basalt spoke the truth,

Lokkon Lo-erara' in the miraculous rock affirmed loud and clear.

379 Simbolon Manik in the stone of basalt was upright,

Lokkon Lo-erara' in the miraculous rock was true of heart.

translated parallel with ammi pamatanna lalan.

mata kalambanan: the right place to cross a river; figuratively, it means the correct way.

tetanan is the parallel of tankean = the act of holding it on the hand.

lindo sara'ka': the front of the comb; it is the parallel of suru': figuratively, it means cleansing offering, in the sense of combing out. 
380 Ma'kadami Simbolon manik kumua:

Iammi la banu' rumampan kapa' tama batu lauluß, Puaß Bassi-bassian, lumokkondakomi lalanmi, ammi pamatanna lalan taßkean suru' tama batu lauluz.

Iammi la ma'tundu maleso umpakulea' pa'sullean allo tama kumila' kalle-kallean,

lumu'pi'komi ta'gulinammi ammi pabotta'na mata kalambanan tetanan lindo sara'ka' tama kumila' kalle-kallean.

381 Apa to nariakan kami tankean suru', to nasaladankan kami tetanan lindo sara'ka'.

382 Ma'kadami Puan Bassi-bassian kumua:

Apa to disana tankean suru', pa to pusa'pa te batu ba'taßku?

Ma'tundu malesomi Usuk saßbamban kumua:

Apa tu diganti tetanan lindo sara'ka', apa to kalili'pa te karanan inaaßku?

383 Ma'kadami Simbolon manik kumua:

Lando lalannikomi ba'tan rekke ulunna lani', laka pa'taunannikomi lonno' rekke karopokna pandan matari' allo.

384 Ammi sule daa mai ulunna lani' sibaa lonno', lellenkomi tallaß baine, sembankomi uraso randanan.

385 Ammi nanai mamion saßlampa, ammi pamata lalanna pioß saßlampa tama batu lauluß, ammi pabotta'na mata kalambanan pesuß saßdaun tama kumila' kalle-kallean.

386 Iamo disana tankean suru' to, iamo diganti tetaßan lindo sara'ka'.

383 lando lalanni = go on a journey in order to fetch [something]; it is a qualitative compound in which the first word defines the second.

According to tradition, rice was unknown in olden times and millet, and a kind of millet, called lonno', were offered at the offerings in heaven and on earth. At the present time, lonno' is often grown in the Duri territory, in the south of the Toradja country.

laka $=\mathrm{far}$; it is a poetical word and a variant of lanka.

384 tallan baine $=$ female bamboo.

385 pion $=$ rice or meat cooked in a bamboo container; pion sanlampa $=$ one internode full of cooked rice; it is given as an offering to the gods. This is the simplest offering; no offering animal is slaughtered.

pesun: the offering meal placed on a banana leaf; it is a derivation of isun $=$ to sit. 
380 Simbolon Manik said:

"If thou wishest positively to conclude a marriage in the stone of basalt, Puan Bassi-bassian, retrace thy steps and effect the fulfilling of the rites of the atonement offering as thy guide, in order to enter the stone of basalt,

if thou wouldst assuredly enter into a union in the miraculous rock, then make a detour in thy path and make the performing of the ritual of the cleansing offering, thy lead into the miraculous rock.

381 "For we are people who are cared for by the fulfilling of the rites of the atonement offering,

we are persons who are cherished by the performing of the ritual of the cleansing offering.

382 Then said Puan Bassi-bassian:

"What is the meaning of that which is called the fulfilling of the rites of the atonement offering, for my innermost being is now like that of a bewildered person?"

Usuk Saybamban then asked, loud and clear:

"What is meant by that which is also named the performing of the ritual of the cleansing offering, for the kernel of my inwardness is now in the state of one who is confused?"

383 Then said Simbolon Manik:

"Go on a long journey, to the North, to the head of the firmament, in order to fetch the millet,

undertake a distant tour, lasting some seasons, to the northward, to the upper part of that which lies stretched out, round, like the disc of the sun, with the object of bringing back the lonno' millet."

384 "When thou returnest with the lonno' millet, from the North, from the head of the firmament,

then cut down a thick kind of reed; then fell the wild sugar cane on the river bank."

385 "So that thou canst offer an internode of it full of food, as thy guide to enter the stone of basalt.

so that thou mayest make a leaf covered with offering food, thy lead into the miraculous rock."

386 "That is what is called the fulfilling of the rites of the atonement offering,

that is what is also named the performing of the ritual of the cleansing offering." 
387 Ullando lalannimi ba'tan Usuk sazbamban rekke ulunna lani', ullaka pa'taunannimi lonno' Puaß Bassi-bassian rekke karopokna pandan matari' allo.

388 Sulemi daa mai ulunna lani', ullellenmi tallaß baine, ussembanmi uraso randanan, nanai mamion sanlampa.

389 Anna pamata lalanna pion sanlampa tama batu lauluß, anna pabotta'na mata kalambanan pesuß saßdaun tama kumila' kalle-kallean.

390 Tibua' teßkomi Simbolon manik lanmai batu lauluß, taßsu batakanmi Lokkon loerara' lanmai kumila' kalle-kallean.

391 Turu-turu mamma'mi lan rampanan kapa' Usuk saßbamban, leza' penamilemi lan pa'sullean allo Puaß Bassi-bassian.

392 Dadimi buanna rampanan kapa' saßbua bannaß, takkomi kamaseanna pa'sullean allo sankaju loli.

393 Kasalle dadinna, marumbo garaganna.

394 Disanami Puan Matua, digantimi To Kaubanan, disaßami Puaß Bassi-bassian, Usuk saßbamban, disanami Puaß Amboamboan, Gauntikembon.

395 Umpatuka'omi pa'ba'taßan Puan Matua, umpasolo'mi pa'inaan To Kaubanan.

396 Kasaloß-salonmi lan taßzana laßi', undaka' saßdeatanna la narampananni kapa', tipandaju-dajumi lan masuaßgana to paoßanan, untuntun saßkapuaßanna la napakulea'i pa'sullean allo.

397 Apa tae' sazdeatanna natiro lindo, taß den saßkapuaßanna natontoni rupa kalua'.

398 Umbaliaßanomi batu ba'taßna Puaß Matua, umbibi'mi karaßan inaanna To Kaubanan.

390 tibua' tenko = pushed as one would push a plough. batakan = pole of a plough, and see 596 . tansu batakan $=$ to protrude like the pole of a plough.

391 turu-turu is a kind of centipede which, when touched, rolls itself up into a small ball. 
387 Then Usuk Sambamban made the long journey to the North, to the head of the firmament, in order to fetch the millet,

thereon Puan Bassi-bassian undertook a distant tour, lasting some seasons to the northward, to the upper part of that which lies stretched out, round, like the disc of the sun, with the object of bringing back the lonno' millet.

388 Returning from the North, from the head of the firmament, he cut down a thick reed; he felled the wild sugar cane on the river bank, in order to fill an internode of it with food and cook it.

389 And he offered an internode full of food, as his guide to enter the stone of basalt,

and he made a leaf, covered with food, his lead into the miraculous rock.

390 Then Simbolon Manik came straight out of the stone of basalt, thereon Lokkon Lo-erara' stepped directly out of the miraculous rock.

391 Usuk Saßbamban was as steadfast in the marriage as a centipede in a deep sleep,

Puan Bassi-bassian was constant in the union, like an adult ruminating bull.

392 Then a single fruit of the marriage was born,

thereon came into the world, the sole gift of the union, well-shaped.

393 He reached maturity,

his form developed fully.

394 He was named Puan Matua, and his other name was To Kaubanan, Usuk Saßbamban was named Puaß Bassi-bassian, Gauntikemboß was called Pußa Ambo-amboan.

395 Puan Matua caused thoughts to arise,

To Kaubanan made the reflections sink down.

$396 \mathrm{He}$ went hither and thither in the centre of the firmament, seeking the one who, like himself, was a deity, in order to conclude a marriage with her,

he roamed far and wide in the highest part of the all-covering roof, trying to find the one who, as he did, bore the title of lord, so that he could enter into a union with her.

397 But he could cath no sight of the face of the one who, like himself, was a deity,

there was no one who, as he did, bore the title of lord, whose countenance he could behold.

398 Then Puaß Matua brought his innermost being into movement, thereon To Kaubanan brought the kernel of his inwardness into action.

Verh. dl. 45 
399 Ungaragami tan mabeko masiri', untampami taß matumpa' makairi.

400 Malemi undedek randan pudukna indo' to kumombonna, tibalikmi untala'pi' dara' lezko lilana to mendadianna.

401 Baßunmi mekutana london lako indo' to kumomboßna, dionmi metinti masian lako to mendadianna,

402 kumua: Denparaka sanserekammi lan batu lauluß la kurampanni kapa'? Denparaka saßpa'duanammi lan kumila' kalle-kallean la kupakulea'i pa'sullean allo?

403 Apa lilinmo' buntu bojo' undaka' saßdeatanta la kurampanni kapa', natae' kutiro lindo,

tikumo' tanete malupu' untuntun saßkapuaßanta, anna taß den kutontoni rupa kalua'.

404 Ma'kada toßanmi indo' kumomboßna kumua: Denpa saßserekanta lan sazsapa'na batu, apa to naria taßkean suru', ma'tundu malesomi to kumombonna kumua: Denpa saßpa'duananta lan sankalada'na kumila' kalle-kallean, apa to nataranak tetaßan lindo sara'ka'.

405 Ma'kadami Puaß Matua kumua: Apa to disaßa taßkean suru', apa to pusa'pa batu ba'tanku?

Tiapai to diganti lindo sara'ka', pa to kalilipa karanan inaaßku?

400 undedek = to beat, to strike a drum.

401 mekutana london $=$ to call like a cock; the cock thus addresses himself to the hens.

402 sanserekan $=$ that which belongs to a part torn off the main body. 
399 Then he created the one who was not awkward or shy, thereon he fashioned the one who was not bashful or clumsy.

400 Then he went knocking on the tips of the lips of the mother who bore him,

then he returned to set in motion that uttered by the words, in their regular order, by the tongue of the one who brought him into the world.

401 Then he stood up, and persistently put the question to the mother who bore him,

there below, he asked clearly and distinctly, of the one who brought him into the world:

402 "Is there in the stone of basalt one who is thy group member, with whom I could conclude a marriage,

is there in the miraculous rock one with whom thou art bound in one community, with whom I might enter into a union?"

403 "Because I have walked round that mountain, weary of seeking the one who, like us, is a deity, in order to conclude a marriage with her, but I did not see her face,

I have paced round that hill, exhausted by endeavouring to find the one who, as we do, bears the title of lord, but I did not catch sight of the countenance of anyone."

404 Then the mother who bore him spoke truthfully:

"There is one who is thy group member, in a part of the stone, and she is the one who is cared for by the fulfilling of the rites of the atonement offering."

Then the one who brought him into the world spoke, loud and clear: "There is another one who, with us, is bound in one community, in a part of the miraculous rock, and she is the one who is cherished by the performing of the ritual of the cleansing offering."

405 Then said Puan Matua:

"What is the meaning of that which is called the fulfilling of the rites of the atonement offering, for my innermost being is like that of a bewildered person?"

"What is meant by that which is also named the performing of the ritual of the cleansing offering, for the kernel of my inwardness is in the state of one who is confused?" 
406 Nakuami indo' to kumombonna: Susiko ambe' to kumombonmu; lando lalanniko ba'tan rekke ulunna lani', laka pa'taunanniko lonno' rekke karopokna pandan matari' allo.

407 Musule daa mai ullelleß tallaß baine, ussemban uraso randanan.

408 Munai mamion saßlampa ba'tan, ammu pamata lalanna pioß saßlampa tama batu lauluß, ammu pabotta'na mata kalambanan pesuß saßdaun tama kumila' kalle-kallean.

409 Iamo disaßa taßkean suru' to, iamo diganti tetaßan lindo sara'ka'.

410 Umpamata lalannami pion saßlampa Puaß Matua tama batu lauluß, umpabotta'nami mata kalambanan pesur sandaun To Kaubanan tama kumila' kalle-kallean.

411 Randukmi tibua' tenko Simbolon manik lanmai batu lauluß, tipamulannami Lokkon loerara' taßsu batakan lanmai kumila' kallekallean.

412 Disanami Arraß dibatu, diganti Sulo taronko malia'.

413 Turu-turu mamma'mi lan rampanan kapa' Puaß Matua, leza' penamilemi lan pa'sullean allo To Kaubanan.

414 Umpatuka'mi pa'bataßan Puaß Matua sola Arraß dibatu lan taßßana laßi',

umpasolo'mi pa'inaan To Kaubanan sola Sulo taroßko malia' lan masuaßgana to paozanan.

415 Belanna tae'pa to sanda razka'na natiro lindo, taß denpa to ganna' tarunona natontoni rupa kalua'

416 Belanna madaraßpa to sanda raßka'na, matalantanpa to ganna' tarunona.

412 Arran Dibatu = The Radiance in the Stone.

Sulo Taronko Malia' $=$ The Torch of the Hard Rock. 
406 Then the mother who bore him said:

"For thee it is necessary to do what thy father who begat thee did, go on a long journey, to the North, to the head of the firmament, undertake a distant tour, lasting some seasons, to the northward, to the upper part of that which lies stretched out, round, like the disc of the sun."

407 "When thou returnest from the North, cut down a thick reed, fell the wild sugar cane on the river bank."

408 "In order to fill an internode full of food, as thy guide to enter the stone of basalt,

so that thou mayest make a leaf covered with offering food, as thy lead into the miraculous rock."

409 "That is what is called the fulfilling of the rites of the atonement offering,

that is what is also named the performing of the ritual of the cleansing offering."

410 Then Puan Matua filled an internode full of food, as his guide to enter the stone of basalt,

thereon To Kaubanan made a leaf covered with offering food, as his lead into the miraculous rock.

411 Then the noble lady came straight out of the stone of basalt, thereon the woman of exalted rank stepped directly out of the miraculous rock.

412 She was called Arran Dibatu, and her other name was Sulo Taronko Malia'.

413 Puan Matua was as steadfast in the marriage as a centipede in a deep sleep,

To Kaubanan was constant in the union, like an adult ruminating buffalo bull.

414 Puan Matua, with Arran Dibatu, caused thoughts to arise in the centre of the firmament,

To Kaubanan, with Sulo Taronko Malia', made the reflections in the highest of the all-covering roof, sink down.

415 Because they did not then see the ones whose limbs are complete, nowhere did they catch sight of the ones whose members are entire.

416 For the ones whose limbs are complete were scarce,

few in number were the ones whose members are entire. 
417 Ma'kadami Arraß dibatu kumua: Lando lalannikomi bulaan matasak rokko kalambunan allo, Puaß Matua!

Laka pa'taunannikomi nane' taß karauan rokko kabotoan kulla', To Kaubanan!

418 Umpatianka' mi bate lentekna Puaß Matua male rokko rampe matampu', umpatirimbami pessoenanna To Kaubanan male rokko kabotoan kulla'.

419 Tae' natiro lindo bulaan matasak Puaß Matua dion kalambunan allo, taß den natontoßi rupa kalua' nane' taß karauan dion kabotoan kulla'.

420 Sulemi Puan Matua dion mai, tibalikmi To Kaubanan.

421 Ma'kadami Arraß dibatu kumua: Umbami bulaan matasak?

Ma'tundu malesomi Sulo taronko malia' kumua: Umbami nane' taß karauan?

422 Ma'kadami Puaß Matua kumua: Tae' aku kutiro lindo, taß den aku kutontoni rupa kalua'.

423 Ma'kadami Arraß dibatu kumua:

Sulekomi rokko kalambunan allo, dion ia kalimbuan boba nanii bulaan matasak la miseno tingi.

Ma'tundu malesomi Sulo taroßko malia' kumua:

Tibalikkomi rokko kabotoan kulla', pa dion ia to' mata uai nanii nane' taß karauan, la miemboß pinamasak dioß to' mata uai nane' taß karauan.

424 Sulemi Puan Matua rokko kalambunan allo, tibalikmi To Kaubanan rokko kabotoan kulla'.

Naseno tingimi dion kalimbuaß boba bulaan matasak, naembon pinamasakmi dion to' mata uai nane' taß karauan.

425 Ponno sepu'nami Puaß Matua bulaan matasak, lempan karopi'nami To Kaubanan nane' taß karauan.

423 miseno tingi $=$ thou must shake it about as though it were dark red beads; these dark red beads are valuable and must not be handled carelessly.

pinamasak (the form pidamasak also occurs): I could not get an explanation of this word. In view of the fact that this form is used as the parallel of ting $i=$ dark red bead, it may be a derivation of masak = ancient dark yellow bead; such beads are of great value.

patuo $=$ to breed, to rear. There is an unusual pina-form in the South Toradja language, namely, pinatuo, an in-form of patuo. Pinatuo describes the pig which brings blessings and life by virtue of its being the offering. 
417 Then said Arraß Dibatu:

"Go on a long journey, Puan Matua, to the place where the sun descends, in order to obtain the pure gold,

undertake a distant tour, lasting some seasons, To Kaubanan, to the region where the shining one sinks down, with the object of acquiring the unalloyed gold."

418 Then Puan Matua rose to his feet and went towards the West,

To Kaubanan swung his arms in the direction where the shining one sinks down.

419 Puan Matua caught no sight of the pure gold at the place where the sun descends,

nowhere did he see the unalloyed gold in the region where the shining one sinks down.

420 Puaß Matua returned from there,

To Kaubanan went back.

421 Then said Arraß Dibatu:

"Where is the pure gold?"

Then said Sulo Taroßko Malia', loud and clear:

"Where is the unalloyed gold?"

422 Puan Matua replied:

"I caught no sight of it, nowhere did I behold it."

423 Then said Arran Dibatu:

"Return to the place where the sun descends, there, in the unfailing well, is the pure gold; thou must sift it as though it were dark red beads."

Thereon Sulo Taronko Malia said, loud and clear:

"Go back to the place where the shining one sinks down, for there, in the welling-up spring below, is the unalloyed gold; wash it in the spring, as if it were as precious as dark yellow beads."

424 Then Puan Matua returned to the place where the sun descends, thereon To Kaubanan went back to the region where the shining one sinks down,

he sifted the pure gold in the unfailing well, as though it were dark red beads,

he washed the unalloyed gold in the welling-up spring, as if it were as precious as dark yellow beads.

425 The sirih pouch of Puan Matua was full of the pure gold, the bag of To Kaubanan, made of the leaves of the sugar palm, was brimful with the unalloyed gold. 
426 Sulemi dion mai kalambunan allo, tibalikmi dion mai kabotoan kulla'.

427 Rampomi lan taßnana lani', tidukunmi lan masuangana to paoßanan.

428 Umbaliananomi batu ba'tanna Puaß Matua lan taßßana laßi' sola Arraß dibatu, umbibi'mi karanan inaanna To Kaubanan sola Sulo taroßko malia' lan una'na to paozanan.

429 Digaragammi kurin-kurin batu bulaan matasak, ditampammi gusi malia' nane' taß karauan.

430 Dipabendanmi sauan sibarruß lan taßßana lani', dipatunannaßmi sulin pada dua lan masuangana to paozanan.

431 Dibolloan barra'mi bulaan matasak tama sauan sibarruß, dibaku amborammi nane' taß karauan tama sulin pada dua.

432 Dadimi to sanda karua lanmai sauan sibarruß, anakna sauan sibarruß, takkomi to ganna' bilananna lanmai sulin pada dua, boßsunna sulin pada dua.

433 Didandan bulaanmi to sanda karua dio salianna sauan sibarruß, dibato' batan-batanmi to ganna' bilaßanna dio birinna sulin pada dua.

434 Kasallemi to sanda karua, lobo'mi garaganna to ganna' bilazanna.

435 Apa nene'ta manna Datu Laukku' ma'rupa tau.

436 Pada umposazami sazanna to sanda karua, pada umpogantimi pa'gantiananna to ganna' bilazanna.

437 Disanami Datu Laukku', diganti Datu baine, disanami Allo tiranda, nene'na ipo.

438 Disaßjami Laußku, nene'na kapa', disaßami Poß Pirik-pirik, nene'na uran.

$428 u n a^{\prime}=$ pith, marrow, soft heartwood; here it is the parallel of tamya with the meaning of middle; una'na to paonanan = the centre of the all-covering roof, the zenith of the firmament.

433 dibato' batan-batan $=$ they were arranged like small gold beads; these small gold beads are set evenly in the armband.

435 Datu Laukku' is the ancestress of mankind. $L a$ is the Buginese article used before the names of men. $U k k u^{\prime}$ is a Sa'danese word for the short cries which newlyborn children utter.

438 Pon Pirik-pirik = Lord Small Windmill; pirik-pirik is a small windmill used to drive away the paddy birds from the ricefields, and see 554. 
426 Then he returned from the place where the sun descends, thereon he went back from the region where the shining one sinks down.

$427 \mathrm{He}$ reached the centre of the firmament, he arrived forthwith at the highest part of the all-covering roof.

428 Puan Matua, with Arran Dibatu, brought his innermost being into movement in the centre of the firmament,

To Kaubanan, with Sulo Taronko Malia, brought the kernel of his inwardness into action in the highest part of the all-covering roof.

429 A utensil like an earthen cooking pot was made for the pure gold, a basin of hard earthernware was shaped for the unalloyed gold.

430 A pair of bellows, belonging together, was put in the centre of the firmament,

then two blow pipes, of equal size, were set up in the highest part of the all-covering roof.

431 Then the pure gold was cast, like unhusked rice, into the pair of bellows belonging together,

thereon the unalloyed gold was poured, like seed, in great quantity, into the two blow pipes of equal size.

432 Then from the pair of bellows belonging together, came forth all eight children of the pair of bellows belonging together,

from the two blow pipes of equal size, there came into the world the ones whose number was complete, the offspring of the two blow pipes of equal size.

433 All eight were set up, as though they were gold, in a row, outside the pair of bellows belonging together,

the ones whose number was complete, were placed carefully at the side of the two blow pipes of equal size.

434 They reached maturity, the forms of the ones whose number was complete, developed fully.

435 But only our ancestress, Datu Laukku', had the form of a human being.

436 Each of the eight had a name, each of the ones whose number was complete, received his other name.

437 The first was called Datu Laukku', and her other name was Datu Baine,

the second was named Allo Tiranda, he was the creator of the tree of poison.

438 The third was called Launku, he was the parent of the cotton, the fourth was named Pon Pirik-pirik, he was the creator of the rain. 
439 Disanami Menturiri, nene'na manuk, disanami Manturini, nene'na tedon.

440 Disanami Riako', nene'na bassi, disazami Takkebuku, nene'na bo'bo'.

441 Aunna to sanda karua naambo' Puaß Matua rokko tikallebona lombok, osinna to ganna' bilaßanna nasioran To Kaubanan rokko tikallebona tanete.

442 Sanda boninna tuo nasanmo disaßanna kaju, lobo' nasaßmo tanan-tananan.

443 Denmo nene'na tallaß, denmo nene'na kalosi, denmo nene'na punti, denmo nene'na induk sia mintu'na den nasaßmo lan kapadaßanna.

444 Nene' mendeatanta Datu Laukku' naulaß rampanan kapa' tama to' bena' kumpaß, nabalajanni pa'sullean allo tama to' kulo'.

445 Lanmi to' kaluku siajun sirampanan kapa' Bonga Lani'na, sipakuleasan pa'sullean allo Datu muane.

446 Mentambenmi Allo tiranda lako kaju todir,, umpakulea'mi pa'sullean allo lako kaju lando samara.

447 Nakua: Nakasalle dadinku dio kaju todin, nalobo' garagaßku dio kaju lando samara.

Anna te'bakki liteku Datu Laukku', napatamai tambila tua, aßku direre' sola lempujaß api, anna kalondai boba, aßku dipale'ke' giu-giu.

448 Napatajanan bataß dikalena saßserekaßku Datu Laukku', naparandanan bataß dikalena saßserekaßku Datu Laukku', ke den to la patenko lullu'.

449 Napatajanan tondon to batanna saßpa'duanazku Datu Laukku', ke la den salaga mennopaz.

439 In strophe 466 the progenitor of the fowl is called Puan Maro $=$ Lord Who Is Frenzied; maro $=\mathrm{mad}$; the frenzy of animals; maro-maro $=$ idiot, weak of understanding. Maro is also the name of the ritual to drive away sickness, for which purpose fowls are offered exclusively.

During the performing of these rites, some people fall into a trance after a stimulating dance and then extraordinary things are done.

Manturini the progenitor of the buffalo.

440 Riako' also Datu Diako' = the progenitor of iron.

Takkebuku = Having no Kernel; comes from tankebuku= having no core.

444 nabalayanni $=$ he bound her with a liana; balayan: a moderately thick liana.

446 mentamben $=$ to lay one's leg over someone.

kayu todin $=$ speckled tree, i.e. the tjendana tree.

447 tambila: container for the small arrows of the blow pipe. In olden times, these small arrows were often smeared with poison from plants. 
439 The fifth was called Menturiri, he was the progenitor of the fowl, the sixth was named Manturini, he was the begetter of the buffalo.

440 The seventh was called Riako', he was the parent of iron, the eighth was named Takkebuku, he was the creator of cooked rice.

441 The ashes of all eight of them were strewn on the declivity of the valley by Puan Matua, the cinders of the ones whose number was complete, were shaken over the side of the mountain by To Kaubanan.

442 When the full number of nights had elapsed, all the different kinds of trees began to grow, and they became plants that shot up luxuriantly.

443 And then there was the parent of the thin bamboo, then there was the creator of the areca palm,

there was the father of the banana plant, there was the sire of the sugar palm, and everything was on earth.

444 Our divine ancestress, Datu Laukku' united in marriage in the bending ironwood tree,

she was firmly attached in a union in the breadfruit tree.

445 In the coconut palms swaying towards each other, she concluded a marriage with Bonga Lani'na, she entered into a union with Datu Muane.

446 Allo Tiranda united in a marriage with the tree with streaks on it, he entered into a union with the tree which has long white stains.

447 He said:

"When I have reached maturity in the tree with streaks on it, when my form has developed fully in the tree which has long white stains, then shall Datu Laukku' tap my sap and put it in an old quiver, then shall a little of me be cut up, together with the red wild ginger and a large millipede, and then I shall be spread on the tip of a small arrow."

448 “My group member, Datu Laukku', will keep it for her own person, my group member, Datu Laukku', will save it for herself when there is somebody who would trample on her."

449 "The one with whom I am bound in one community, Datu Laukku' will keep it for her own person, when there is somebody who would tread on her."

449 salaga mennopan $=$ harrow that breaks things down. 
450 Nakuannamo Launku:

La mentambenmo' aku tama randanna bela' umpokaa' malompona padaß.

451 Anna kasalle dadinku, nalobo' garaganku, aßku kendek membua gaun, aßku laßßan menta'bi salebu'.

452 Anku diunu' ten laa-laa, aßku diunu' susi beluak.

453 Anku kombon sarita to lamban, kudadi maa' to unnoron.

454 Aßku kombon doti lani' tuo balo', kudadi maa' taß mate lu'pi'na.

455 Anku lan baka disura' unnarranni sanianaßku, aßku lan tumballan diaßgilo ußkorok saßpa'duanaßku.

456 Naalami sambo boko'na sanserekaßku Datu Laukku', naalami rindin tizajona saßpa'duanazku.

457 Narindizanni datunna anin, natampananni ma'dika darindin.

458 Nakuamo Poß Pirik-pirik:

La mentambenmo' aku lako taßkena gaun, la umpakulea'na' aku pa'sullean allo lako kurapakna taßke salebu'.

459 Nakasalle dadinku, nalobo' garagaß ku, apa akumo susu mammi'na mintu' sanga mairi', akumo panoran kasallena mintu' sola nasaß.

460 Akumo boka' mainnakna saßserekanku, akumo balubu taß sore-sorena saßpa'duanaßku.

461 Katotok-totokmi nene' mendeatanna manuk, katambuli-bulimi nene' kapuaßanna.

462 Dipalumokkonmi lalanna tama sauan sibarruß, dipatumetemi ta'gulizanna tama sulin pada dua.

454 maa' tan mate lu'pi'na = cloth to whose folding up there is no end; a woven cloth which is used regularly.

456 rindin $=$ wall.

458 tankena gaun $=$ branch of a cloud. The progenitor of the fowl acquired his name because of his idiotic behaviour. kurapakna tanke $=$ the thick end of a branch where it joins the trunk.

460 mainnak $=$ oil bearing.

462 dipalumokkon lalanna $=$ his path was folded. 
450 And Launku said:

"I am going to enter into a marriage in the edge of the field,

I shall unite myself with the richness of the earth."

451 "When I have reached maturity, when my form has developed fully, then shall I rise on high and bear fruit, like the clouds,

then I shall shoot upwards and have flowers, like the white mists."

452 "Then shall I be spun, like the threads of a cobweb, then I shall be drawn out, like hairs."

453 "I shall be made into an old long narrow blue woven cloth with a design of men fording a river,

I shall become an old short fabric with a pattern of swimming men."

454 "I shall be made into an old short wide woven cloth with a cross motif on it,

I shall become a fabric to whose folding up there is no end."

455 "Then shall I lie in a basket adorned with a design, cherishing all the precious things put therein with me,

then I shall lie in a carrying hamper on which a wave-shaped pattern is cut, protecting the property that is there with me."

456 "My group member, Datu Laukku', will take me as the covering for her back,

the one with whom I am bound in one community, will use me as protection for the front of her body."

457 "She will shelter herself with me against the Prince of the Wind, she will keep off the Lord of Coolness with me."

458 And Pon Pirik-pirik said:

"I am going to enter into a union with a cirrus cloud,

I shall unite in marriage with a compact mass of mists."

459 "When I have reached maturity, when my form has developed fully,

then shall I be the delicious breast for everything there is, then I shall be the great udder for all that exists."

460 "Then shall I be the rich coconut oil for my group members,

I shall then be the water cask, whose contents never diminish, of the ones with whom I am bound in one community."

461 The divine progenitor of the fowl pecked constantly, his begetter, revered as a lord, dug continually with his beak.

462 Then his way was once more directed back into the pair of bellows belonging together, then his path, on which he went to and fro, was again guided back into the two blow pipes of equal size. 
463 Sule lanmai sauan sibarrun, tibalik lanmai sulin pada dua, ma'kadami kumua:

464 Dendaka kitaß katotok-totok, Puaß!

465 Moi penduaßkan sule tama sauan sibarruß, moi pessanajokakan tibalik tama sulin pada dua, dendaka kitaß katotok-totok, dendaka kitan katambuli-buli!

466 Disanami Puaß Maro.

Nakuamo Puaß Maro:

La metambenmo' aku laßß̧an taßkena lamba', sipentambenan manuk bu'tu iliku, Landokollon,

la umpakulea'mo' pa'sullean allo laßß̧an lolosu porißan, sipakuleasan pa'sullean allo Landobaroko.

467 Dadimi tallo' siannanan dao taßkena lamba', kombonmi amburaß sanda karua dao lolosu porizan.

468 Dadimi pantan ma'laen bulu dao taßkena lamba', kombonmi ma'rupa-rupa dao lolosu porinan.

469 Ia uainna lotoß: suru'na rampe matampu', sara'ka'na kabotoan kulla' dio to diponene'.

470 Rame tasak: suru'na tetean tampo, sara'ka'na pesunagan banne sirenden.

471 Ia karuruß: suru'na ma'bala tedon, sara'ka'na ma'paßkuß karambau.

472 Anna makamban marapuan tedon dipotulak bala, anna masirri manapa' tedoß dipotandi kala'ka'.

473 Ia koro, iamo ia suru'na to pekolon kuse lako tutunna lalan, iamo ia sara'ka'na pande bulaan napoparamae.

466 Landokollo $=$ She Who Has a Long Neck. Landobaroko $=$ She Who Has a Long Throat.

467 amburan $=$ spawn of a fish.

470 tetean $\operatorname{tampo}=$ the act of going across the dyke of a ricefield.

472 dipotandi $k a l a^{\prime} k a^{\prime}=$ they were used as supports for the lower beams on which the floor rests; this refers to the use, in olden times, of the space under the house for stabling the buffaloes.

473 to pekolon kuse = those who carry on their backs a pouch made of the skin of a marsupial. Goldsmiths carry on their backs such a pouch in which they put their tools.

napoparamae $=$ with which they play; paramae is a variant of paramai, cp., Malay pĕrmai. 
463 He turned aside from the pair of bellows belonging together, he turned round from the two blow pipes of equal size, and said:

464 "Lord, would it be possible for us not to peck continually?"

465 "Even if we do go back twice into the pair of bellows belonging together,

even if we do return a second time into the two blow pipes of equal size,

would it be possible for us not to peck constantly, would it be possible for us not to dig continually with our beaks?"

466 He was named Puan Maro.

Puan Maro said:

"I am going to enter into a union above, on the branch of the fig tree, with the hen, Landokolloy, that has appeared from its depths,

I shall unite in marriage with Landobaroko, on the top of the low tree."

467 Then six plus six eggs came to lay on the branch of the fig tree, on the top of the low tree, a complete number of eight eggs was laid.

468 Then on the branch of the fig tree, were born the ones that have distinct feathers,

thereon on the top of the low tree, there came into the world, the ones which have varied colours.

469 Their progeny were:

the black fowl, the atonement offering at the West,

the cleansing offering at the place where the shining one sinks down, for the ones who are revered as ancestors.

470 The yellow-brown fowl, it is the atonement offering for the cultivation of the ricefields,

the cleansing offering for the places, one after the other, in the sawahs, where the offerings are brought.

471 The black fowl with white spots, it is the atonement offering for the stalling of the buffaloes,

the cleansing offering for the stabling of the kerbau.

472 So that the progeny of the buffaloes may be great in number, to serve as supports for the space under the house,

in order that there may be a tremendous quantity of kerbau, to serve as the props for the lower beams on which the floor rests.

473 The white and black fowl, it is the atonement offering for the ones who have carried the skin of a marsupial on their backs during their whole journey,

the cleansing offering of the goldsmiths, which they always perform. 
474 Ia uran-uran: suru'na kombon marapuan.

475 Ia seppaga, iamo sara'ka'na induk masirri manapa', anna kerara uainna salle balu'bu'.

476 Ia sella' sikambi' kalandona buntu, suru'na to ditanan indo' lako pare tallu bulinna.

477 Ia sella' mabusa baba'na: sara'ka'na uainna Datu Maßkamma', saßka' beloß-belonanna ke'te' tallu eterna, nakendek membua rara', nalaßßan menta'bi bulaan.

478 Ia uainna busa' sikambi' lumbaa lani', ke bendanni paraßka dialuk.

479 Ia bullau napopakuli ura' to makuju lankan, napopetaßka' ura' to maossa' manuk-manuk.

480 Ia buri', iamo napaninoi anak dipajuni, napatakinni tampa to Darru', napaselle'i pa'komboß to Balanda.

481 Ia dukamo urra'ta' kasembananna lan taß̧ana lazi', iamo ullaßkanni sanda salunna lan masuaßgana to paozanan.

482 Nakuamo Riako':

La mentambenmo' tama batu lauluß, la umpakulea'mo' pa'sullean allo tama kumila' kalle-kallean.

474 kombon marapuan $=$ the extensive cultivation; it refers to the cultivated area belonging collectively to the whole clan house.

475 masirri $=$ dreadful, frightful.

476 indo': the full form is to indo' or indo' padan = the leader of the rice cultivation and the offerings attendant thereon; see strophe 4, II A. In some territories, when the rice has put forth its fruit, the indo' padan goes to a hill and there offers to the gods the cock mentioned in this strophe.

477 Datu Mankamma' is the name of the ancestor of the leaders of the rice cultivation; he is also called Karaen Ma'loko-loko = Silent Lord. Both ma'loko-loko and kamma' mean to be silent. The Makassarese word Karaen occurs occasionally in South Toradja proper names, for example, Karaen Dua, Ne' Karaen.

Makaraen, the parallel of madatu, means noble, illustrious.

478 lumbaa lani $i^{\prime}=$ bamboo erected heavenwards. At the bua' feast, this thick bamboo stands upright by the platform from which the to minaa, the leaders of the offerings, pronounce the benedictory prayers. A small basket containing a white fowl is attached to the top of this bamboo, as well as a rope of rattan. The various participants at the feast tug at this rope until someone breaks the bamboo and pulls down the basket. He then receives the white fowl.

479 to makuyu lankan = he who has the dishevelled feathers of a [sick] harrier. "people who are exhausted", means those who are fatigued by their heavy work. to maossa' manuk-manuk $=$ he who has the ruffled feathers of a [sick] bird.

480 napaninoi anak dipayuni= with which the young people of high rank play; this refers to cock fighting: anak dipayuni $=$ those over whom a sunshade is held. In olden times, the adat chiefs and the members of their lineages were entitled 
474 The black fowl with white spots, it is the atonement offering for the extensive cultivation.

475 The brown cock with spots, it is the atonement offering for the tremendous quantity of sugar palms,

so that the juice of the ones that have large main leaf ribs, may flow like blood.

476 The brown cock with white feet, it is associated with the high mountain,

it is the atonement offering for the ones who are placed as guardians over the three-eared rice.

477 The brown cock with white ear lobes, it is the cleansing offering for the descendants of Datu Mankamma',

the required ritual for the cut one, branched in three,

so that it grows and has golden fruit; so that it shoots up and bears golden blossoms.

478 The progeny of the white fowl are associated with the bamboo erected towards the sky,

when the stake, at which the ritual is performed, stands upright.

479 The grey fowl is used as medicine for the muscles of people who are exhausted,

it serves as a powerful remedy for the fibres of the ones weakened by sickness.

480 The speckled cock is the one with which young persons of high rank play,

they attach firmly to it that which is shaped by the people of Darru', they fasten to it that which is made by the Dutch.

481 They [the speckled cocks] also cut the knot in the decisions, in the centre of the firmament,

they [the speckled cocks] testify to that which is right, in the highest part of the all-covering roof.

482 Riako' said:

"I am going to enter into a union in the stone of basalt,

I shall unite in marriage in the miraculous rock."

to a sunshade made of the leaves of the kambuno palm, (Livistona rotundifolia). The leaves were stretched over a framework of ribs of bamboo.

"that which is shaped by the people of Darru" ", and "that which is made by the Dutch", are artificial spurs, the small knives, which are attached to the natural spurs of fighting cocks. The term to Darru' could not be explained to me. Tampa to Darru': the ironwork of the people of Darru'.

481 The idea in this strophe is of judgement arrived at by a cock fight; urra'ta' kasembaranna $=$ settling finally by means of a trial.

Verh. dl. 45 
483 Anna kasalle dadinku lan batu lauluß, nalobo' garagaßku lan kumila' kalle-kallean.

484 Anku tilu'bak sisama rindinß, kutilu'bak ten usuk penamile.

485 Kusule tama sauan sibarruz, kutibalik tama sulin pada dua.

486 Kukombon tonapa londonna, kudadi indo' simanßkoro.

487 Manturini mentamben laßßan kalandona buntu sipentambenan Laelo', umpakulea'mi pa'sullean allo laßßan patioranna tanete.

488 Dadimi Tandukuaka', dadimi Tandukpaku.

489 Anna makamban marapuan dao kalandona buntu metaruk biaß, anna masirri manapa' dao patioranna tanete metanke luana.

490 Anna batu matei buntu, nakalembani tanete ullela tombaß.

491 Manda' ia lan baka disura' nene'na pare Takkebuku, bintin ia lan tumballan diaßgilo to dolo kapuaßanna ke'te' tallu etenna.

492 Ma'kadami Takkebuku kumua:

Mapusanmo' lan baka disura', makammu'mo' lan tumballan diaßgilo.

493 Ma'kadami Puaß Matua kumua:

Kusaza melomo inanmu lan baka disura', maballomo esußammu lan tumballan diaßgilo.

488 Tanduk $U a k a^{\prime}=$ The One Who Has Horns Like a Root; i.e., horns sticking straight out. Tanduk Paku= The One Who Has Horns Like a Fern; i.e., horns bent outwards. 
483 "When I have reached maturity in the stone of basalt, when my form has developed fully in the miraculous rock."

484 Then shall I be stripped of the outermost layer, and shall be like a wall,

then I shall be denuded of my exterior thickness, and shall become like a rib of a buffalo bull."

485 "Then shall I return, and go into the pair of bellows belonging together,

then I shall go back, in order to enter the two blow pipes of equal size."

486 "I shall become the most magically powerful sword with a blunt end, then shall I become a sword with a broad tip."

487 Manturini ascended the high mountain and entered into a union with Laelo', going upwards, he united in marriage on the high hill.

488 Then Tanduk Uaka' was born, and came into the world Tanduk Paku.

489 They became a very large herd, which sought the shoots of the arrow cane,

they became a horrifying huge multitude on the highest mountain, seeking grass stems.

490 They caused the moutain to erode,

they made the hill fall apart, like hard clay, making the ponds always larger.

491 The parent of rice, Takkebuku, was immoveable in the basket adorned with a design,

the creator of the cut one, branched in three, revered as a lord, was immobile in the carrying hamper, on which a wave-shaped pattern is cut.

492 Then said Takkebuku:

"I am warm in the basket adorned with a design,

I am glowing hot in the carrying hamper, on which a wave-shaped motif is cut."

493 Then said Puan Matua:

"I think that thy place in the basket adorned with a design is a good one,

that thou art well-placed in the carrying hamper, on which a waveshaped pattern is cut." 
494 Apa ma'kada Takkebuku kumua:

Tae' nala lobo' garaganku lan tumballan diaßgilo.

495 Ma'kadami Puaß Matua kumua:

$\mathrm{Na}$ umbamo la munii mentamben nakita inaammu?

496 Nakua: La mentambenmo' rokko randanna limbon, kusitaranak lombu masakka',

la umpakulea'mo' pa'sullean allo rokko tetukna minaßa, aßku sisaladan tana madarindin.

497 Anku taß tipodo' lolo, aßku taß sumpu uaka'.

498 Anna sumarre lobo'ku, ma'kanda-kaßda daunku.

499 Anna boka' mainnakkina' Poß Pirik-pirik dio mai taßkena gaun, anna balubu taß sore-soreina' Landolentek dio mai kurapakna tanke salebu'.

500 Apa iamo susu mammi'ku, iamo panoran kasalleku.

501 Aßku dendek membua rara' makamban marapuan, aßku laßßan menta'bi bulaan masirri manapa'.

502 Anna popakkanna' taßkean suru' dio saßserekaßku Datu Laukku', naposumallaßna' tetaßan lindo sara'ka' dio saßpa'duanaßku.

503 Anna popamuntu marendeßna' saßserekanku Datu Laukku', anna pobajak sae lakona' saßpa'duanaßku.

504 Manda'mi lan rampanan kapa' Datu Laukku', bintinmi lan pa'sullean allo.

505 Dadimi buanna rampanan kapa' saßbua bannaß, takkomi kamaseanna pa'sullean allo saßkaju loli.

506 Kasalle dadinna, lobo' garaganna.

498 sumarre $=$ luxuriant as serrai grass: it is a um-form of sarre = sĕrai grass (Andropogon Nardus Linn.), a grass with fragrant leaves which forms large clumps.

502 pakkan = the weft thread; it is so wound in the shuttle that it can pass through the warp; it is the partner of the warp; it belongs, as it were, to the warp. sumallan = the raised warp threads; the raised warp threads are, as it were, the partners of the unraised ones.

503 anna popamuntu marendenna' Datu Laukku'= then shall I be as a piece of durable, magical hard iron of a roasting dish for Datu Laukku'; pamuntu= piece of wrought iron.

bayak = the part of the steel of the blade of a knife or a sword that is slightly whiter. 
494 But Takkebuku said:

"My form will not develop well in the carrying basket on which a waveshaped pattern is cut."

495 Then said Puan Matua:

"What are thy thoughts as regards entering into a marriage?"

496 He replied:

"I wish to enter into a union beneath the bank of a pool, it is my desire to nestle against the cold ground of the morass,

I want to unite in marriage by going beneath the corner of the river mouth, so that I can cherish myself in the cool earth."

497 "So that I can sprout without interruption, so that my roots are nowhere checked."

498 "So that my growth is luxuriant, my leaves thriving, like those of the leek."

499 "So that Pon Pirik-pirik pours upon me from the cirrus clouds, like rich coconut oil,

so that Landolentak fills me from the compact mass of mists, like a water cask whose contents never diminish."

500 "Because he is my delicious breast, he is my large udder."

501 "Then shall I shoot upwards and have luxuriant abundant fruit, then I shall reach maturity, and bear golden blossoms in tremendous quantity."

502 “Then shall my group member, Datu Laukku', by the fulfilling of the rites of the atonement offering, receive me as repayment, then the one with whom I am bound in one community, by the performing of the ritual of the cleansing offering, shall obtain me as recompense."

503 "Then shall I become a source of continual strength for my group member, Datu Laukku',

then I shall be as steel for the one with whom I am bound in one community."

504 Datu Laukku' was steadfast in the marriage, she was constant in the union.

505 Then a sole fruit was born of the marriage, thereon came into the world a single gift of the union, well-shaped.

506 He reached maturity, his form developed fully. 
507 Umposaßami sazanna Manturino, umpogantimi pa'gantiananna Datu muane.

508 Kammami la ma'dulu nene' mendeatanna tedoß, dionmi la sitinti gantian to dolo kapuaßanna karambau.

509 Umbaliazanomi batu ba'tanna Menturino, umbibi'mi karaßan inaanna Datu muane.

510 Rumampanni kapa' tama to' batu tonkon, umpakulea'mi pa'sullean allo tama to' tabaß tua.

511 Sirampanan kapa' Tumba' Sulotabaß.

512 Manda'mi lan rampanan kapa' Menturino, bintinmi lan pa'sullean allo Datu muane.

513 Dadimi buanna rampanan kapa', takkomi kamaseanna pa'sullean allo.

514 Kasalle dadinna, lobo' garaganna umposazami saßanna Tumba'

Bena'kumpaß, umpogantimi pa'gantiananna Datu baine.

515 Narampananmi kapa' To Tanaraßga, napakulea'mi pa'sullean allo Datu muane.

516 Manda'mi lan rampanan kapa', bintinmi lan pa'sullean allo.

517 Dadimi buanna rampanan kapa' titanan tallu, takkomi kamaseanna pa'sullean allo samba' batu lalikan.

518 Kasalle dadinna, lobo' garaganna, pada umposazami saßanna, pada umpogantimi pa'gantiananna.

519 Disanami Kundailani', diganti Datu baine, disanami Kundaitetuk, diganti Datu baine, disanami Kundaibubun, diganti Datu baine.

520 Madarazpa to ditampa tau natiro lindo Puaß Matua sola Arraß dibatu lan taßzana lazi', matalantanpa to sanda ranka'na natontoni rupa To Kaubanan sola

Sulo Taronko malia'.

508 dionmi $=$ it was with a small difference; literally, it was underneath.

510 taban tua: old dragon's blood plant; it is the parallel of the large upright stone, because usually a dragon's blood plant was planted near such a stone.

511 tumba' is a variant of tumban= to spring up; to tumban is the term used to denote the women who are in a state of tabu at the great bua' feast. $T u m b a^{\prime}$ is an honorific used before the names of the women who have become to tumbarn. The initiation rites of the great bua' feast are performed for them, see strophe 565 . 
507 He received the name of Manturino, and his other name was Datu Muane.

$508 \mathrm{He}$ was all but the namesake of the divine progenitor of the buffalo, with only a small difference, he had the other name of the begetter, revered as a lord, of the kerbau.

509 Manturino brought his innermost being into movement, Datu Muane brought the kernel of his inwardness into action.

$510 \mathrm{He}$ concluded a marriage in a large upstanding stone, he entered into a union within the place of the old dragon's blood plant.

511 He concluded a marriage with Tumba' Sulotaban,

512 Manturino was steadfast in the marriage, he was constant in the union.

513 Then the fruit of the marriage was born, thereon came into the world, the gift of the union.

514 She reached maturity, her form developed fully, her name was Tumba' Bena' Kumpan, and her other name was Datu Baine.

515 To Tanaranga concluded a marriage with her, Datu Muane entered into a union with her.

$516 \mathrm{He}$ was steadfast in the marriage, he was constant in the union.

517 Then there were born the fruits of the marriage, a trinity, thereon came into the world, the gifts of the union, a trio, well-shaped, like the stones of the hearth.

518 They reached maturity, their forms developed fully, each of them had a name, each received his other name.

519 The first was called Kundailani, and her other name was Datu Baine, the second was named Kundaitetuk, and her other name was Datu Baine, the third was called Kundaibubun, and her other name was Datu Baine.

520 Puan Matua, with Arran Dibatu, saw that the ones who were created as human beings were seldom in the centre of the firmament, To Kaubanan, and Sulo Taronko Malia', observed that the ones whose limbs were complete were still scarce.

514 bena'kumpan = bending down bena' tree; it is a kind of ironwood tree.

519 The names of the three women mentioned in this strophe are all connected with the word kundai $=$ woman's sarong; $\mathbf{c p}$. the Buginese word makkunrai = woman 
521 Umpatianka'omi bate lentekna Puaß Matua rokko kalambunan allo, umpatirimbami pessoenanna To Kaubanan rokko kabotoan kulla'.

522 Usseno tingimi bulaan matasak dion kalimbuaß boba, unnemboßmi nane' taß karauan dion to' mata uai.

523 Ponno sepu'nami Puaz Matua bulaan matasak, lempan karopi'nami To Kaubanan nane' taß karauan.

524 Suleomi Puaß Matua dioß mai kalambunan allo, tibalikmi To Kaubanan dion mai kabotoan kulla'.

525 Dibolloan barra'omi bulaan matasak tama sauan sibarruß, dibaku amboranomi nane' taß karauan tama sulin pada dua.

526 Dadiomi anakna sauan sibarruß titanan annan, takkomi kamaseanna sulin pada dua ganna' bilaßanna.

527 Aunna to titanan annan nabuanmi Puaß Matua rekke ulunna lani', osizna to ganna' bilaßanna napirikmi To Kaubanan rekke karopokna pandan matari' allo.

528 Tuomi kaju pitu taßkena daa ulunna laßi', lobo'mi kaju pitu daunna daa karopokna pandan matari' allo.

529 Kasalle dadinna to titanan annan, lobo' garaganna to ganna' bilazanna.

530 Pada umposanami sazanna to titanan annan, pada umpogantimi pa'gantiannanna to ganna' bilaßanna.

531 Buza'na disanami Pande Manaraß, diganti Datu muane.

Ma'penduanna disanami Pande Paliuk, diganti Datu muane.

531 Pande Manaraß = Master Carpenter.

Pande Paliuk $=$ Extraordinarily Skilled. 
521 Then Puan Matua rose to his feet and went downwards, to the place where the sun descends,

To Kaubanan swung his arms and went below, to the region where the shining one sinks down.

522 Then he sifted the pure gold, as though it were dark red beads, in the unfailing well, he washed the unalloyed gold in the welling-up spring.

523 The sirih pouch of Puan Matua was full of the pure gold, the bag of To Kaubanan, made of the leaves of the sugar palm, was brimful with the unalloyed gold.

524 Then Puaß Matua returned again from the place where the sun descends,

thereon To Kaubanan went back again from the region where the shining one sinks down.

525 The pure gold was again thrown, like unhusked rice, into the pair of bellows belonging together,

the unalloyed gold was again poured, like seed, in great quantity.

526 Then the six children of the pair of bellows belonging together, were born,

thereon came into the world the complete number of the gifts of the union of the two blow pipes of equal size.

527 Puan Matua threw the ashes of the six to the North, to the head of the firmament,

To Kaubanan shook the cinders of the complete number, northwards, to the upper part of that which lies stretched out, round, like the disc of the sun.

528 Then a tree with seven branches grew there in the North, at the head of the firmament,

luxuriantly shot up a tree with seven leaves, in the upper part of that which lies stretched out, round, like the disc of the sun.

529 All reached maturity, the forms of the complete number developed fully.

530 Each of the six had a name, each of the complete number received another name.

531 The first was called Pande Manaraß, his other name was Datu Muane.

The second was called Pande Paliuk, and his other name was Datu Muane. 
532 Ma'pentallunna disazami Pande Pandita, diganti Datu muane.

Ma'penna'pa'na disaßzami Pande Patanßa', diganti Datu muane.

533 Ma'pellimanna disanami Pande Nunu, diganti Datu muane.

Ma'pennannanna disarami Kambunolani', diganti Ta'duß Kaissanan.

534 Malemi To Tanaranga rekke ulunna lanji' ullellen kaju pitu tankena, pitu daunna, unnuaseimi kaju pantan rupa daa karopokna pandan matari' allo.

535 Soßkami kaju pitu taßkena, pitu daunna, tiboßso'mi rokko to' mata uai.

536 Pusa'mi batu ba'tanna To Tanaranga, kalilimi karanan inaanna Datu muane.

537 Sulemi To Tanaranga daa mai ulunna lani', tibalikmi Datu muane daa mai karopokna pandan matari' allo.

538 Malemi mekutana london lako Puan Matua, tibalik mekutinti masian lako To Kaubanan.

539 Nakua: Maßkamo', Puaß, ullellen kaju pitu taßkena, pitu daunna daa ulunna lan', apa tiborso' ia rokko liku mandalan, mankamo' unnuasei kaju pitu ma'laen rupa, apa tiranduk ia rokko to' mata uai.

540 Ma'kadami Puan Matua kumua:

La taß tibonso'raka rokko liku mandalan, natae' nariai taßkean suru', ma'tundu malesomi To Kaubanan kumua:

La taß tirandukraka rokko to' mata uai, natae' nasaladanni tetanan lindo sara'ka'.

532 Pande Patanza $=$ The One Who Is Capable of Skilful Planning.

533 Pande Nunu= The One Who Gan Observe Well.

Kambunolani? = Sunshade of the Firmament; the name of the ancestor of the to minaa = leaders at the offerings and the people who know the adat prescriptions. There are other names which, like Kambunolani, give their possessors demigod status in the firmament, for example, Arunlani' = King of the Firmament; Lai' Datulani $i^{\prime}$ Queen of the Firmament. Other titles express a relationship with the sun, thereby indicating the prominent status of a person whose ancestors descended from heaven, for example, Saronallo $=$ Hat of the Sun; Ranteallo = Plain of the Sun.

$T a^{\prime}$ dun Kaissanan $=$ Renowned Hat.

According to another informant coming from the Salu group in the Kesu' territory, Tandilino', who travelled northwards after the disaster at Rura, had four carpenters with him; Pon Kalotok (who appeared out of a tree top), Pon 
532 The third was called Pande Pandita, and his other name was Datu Muane. The fourth was called Pande Patanza', and his other name was Datu Muane.

533 The fifth was called Pande Nunu, and his other name was Datu Muane.

The sixth was called Kambunolani?. and his other name was $T a^{\prime} d u n$ Kaissanan.

534 To Tanaranga went to the North, to the head of the firmament, and hacked down the tree with the seven branches and the seven leaves, he felled the tree in the North, which had different forms, in the upper part of that which lies stretched out, round, like the disc of the sun.

535 Then the tree with the seven branches and the seven leaves fell down, thereon it slid into the deep pool beneath, and took root in the spring below.

536 To Tanaranga was bewildered in his innermost being, the kernel of the inwardness of Datu Muane was confused.

537 To Tanaranga returned from the North, from the head of the firmament,

Datu Muane came back from the northward, from the upper part of that which lies stretched out, round, like the disc of the sun.

538 Then he proceeded to put the question to Puan Matua, thereon he turned round and asked continually of To Kaubanan, until it was clear:

539 "Lord, I have hacked down the tree with the seven branches and the seven leaves in the North, at the head of the firmament, but it has slid into the deep pool beneath,

I have felled the tree with the seven different forms, but it has taken root in the spring below."

540 Then said Puan Matua:

"Has it not slid into the pool beneath, because it has not been cared for by the fulfilling of the rites of the atonement offering?"

Thereon spoke To Kaubanan, loud and clear:

"Has it not taken root in the spring below, because it has not been cherished by the performing of the ritual of the cleansing offering?"

Bulukuse $=$ Lord Marsupial Hair; Pon Pusa'bannanna $=$ Lord Whose Threads are Disarranged, and Pon Lamemme' = Lord Gentle One. Pon Lamemme' could make a long beam short at a single blow. He was killed by the other three. $\mathrm{He}$ then laid a curse on the trees that a plague of woodworm and wasps that attack trees would infest them. 
541 Natiro biasa ia naria taßkean suru', mabaßko ia nasaladan tetanan lindo sara'ka'.

542 Ma'kadami To Tanaraßga kumua:

Na umbamo te ba'ten la kupoba'teß, na umba te inaa la kupoinaa?

543 Nakuamo Puaß Matua:

Su'pimi ampo anakna Puaß Maro, alami mimi' kandaurena ri'tik, iamo manuk ma'bulu tingi.

544 Ammu pasiindo'i likaran biaß dio to'na kaju pitu taßkena, pitu daunna, ammu pasisaladanni kolikan tille tanete sola pion marapuan.

545 Siindo'mi likaran biaß, sisaladanmi kolikan tille tanete.

546 Nariami tankean suru', nasaladanmi tetaßan lindo sara'ka'.

547 Lindanmi patoßkon a'pa' dion mai liku mandalan, unnaaßmi lentoß ganna' bilazanna dion mai to' mata uai.

548 Dibaami daa mai ulunna lazi' patoßkon a'pa', dirantemi buntu karua, dilappa'imi tanete ganna bilaßanna.

549 Marantemi buntu karua, lappa'mi tanete ganna' bilaßanna.

550 Dipabendanmi patoßkon a'pa' dao buntu karua, dipatunannaßmi lentoß ganna' bilaßanna dao tanete siannanan.

551 Bendanmi patozkon a'pa', tunannaßmi lentoß ganna' bilaßanna.

$543 s u^{\prime}$ pimi $=$ chip it; take it from it. ampo anak = grandchildren, children.

544 tille: a kind of reed with a soft inside (Andropogon halepensis Stapf.). 
541 "It will be in order when it is cared for by the fulfilling of the rites of the atonement offering,

it will go well with it when it is cherished by the performing of the ritual of the cleansing offering."

542 Then said To Tanaranga:

"What thoughts should I have in my innermost being, what should I think in my heart?"

543 Puan Matua replied:

"Take two or three of the progeny of Puan Maro,

fetch the speckled one of his illustrious descendants, the fowl with the feathers like dark red beads."

544 "Then will it be united with the small offering basket constructed of the interwoven leaves of four reed stalks, at the place of the tree with seven branches and seven leaves,

it will be bound to the small offering basket made of the entwined leaves of the stalks of the mountain reed, together with the many bamboos of cooked rice."

545 Then was it united with the small offering basket constructed of the interwoven leaves of four reed stalks,

then it was bound to the small offering basket made of the entwined leaves of the stalks of the mountain reed.

546 Then was it cared for by the fulfilling of the rites of the atonement offering,

then it was cherished by the performing of the ritual of the cleansing offering.

547 And the four poles rose up out of the deep pool, the supports, complete in number, emerged out of the spring.

548 The four poles were brought from the North, from the head of the firmament, eight mountains were made flat, the hills, complete in number, were levelled out into a smooth terrain.

549 The eight mountains were flattened, the hill, complete in number, became level land.

550 The four poles were erected on the eight mountains, the supports, complete in number, were set up on the hills.

551 Then the four poles stood upright, the supports rose up, complete in number. 
552 Apa baruß-baruß maa'pa ade' tipamulanna lan tanßana lani', garu'ga' doti lani'pa ade' bußa'na lan masuangana to paozanan.

553 Unkandemi ade' taß torakna api bu'tu ibatu, untimbu'mi taß lupa' tarunona kalamban-lamban.

554 Pada umpokalo'mi kalo' kadaanna, ditolloimi uainna Poß Pirik-pirik.

555 Kasalon-salonmi ade' To Tanaranga tama rampe matallo, luminka-minkami Datu muane tama kadellekan kulla'.

556 Naraßimi ade' paßlaa tedoß nene' mendeatanna bai lanmai batu lauluß, tollon kasube rara'na, natandin talinami ade' paßkambi' karambau meninß̧i lanmai kumila' kalle-kallean to dolo kapuaßanna bonde massozgo bisara, tiumba' kalunkun bulaanna.

557 Napatiroanni ade' To Tanaranga.

558 Naalami ade' To Tanaranga lanmai batu lauluß nene' mendeatanna bai, nakala'pami Datu muane to dolo kapuananna bonde massongo bisara.

559 Nagaragammi ade' paßkuß malona'na dao patoßkon a'pa', narandukkammi bonton malolaßan dao lentoß ganna' bilaßanna.

560 Makamban marapuammi lan paßkuß malona'na, umbia' ra'tuk, masirri manapa'mi lan bonton malolanan, lo'dok kano tuak.

561 Narampanannimi kapa' Kambunolani' Kundailani', napakulea'imi pa'sullean allo Ta'dun Kaissanan Datu baine.

562 Narampanannimi kapa' Pande Pataßßa' Kundai Tetuk, napakulea'imi pa'sullean allo.

563 Narampanannimi kapa' Pande Paliuk Kundai Bubun, Pande Nunu rumampan kapa' tama padaß di Illin. 
552 But, so we are told, at first it was a booth of old short wide woven cloths that stood in the centre of the firmament,

it was, so it was said, in the beginning, a dwelling place of old short wide fabrics with a cross motif on them, which was there in the highest part of the all-covering roof.

553 The fire emanating from the stone ate that which it had not itself obtained,

it partook of that which was not the produce of its fingers,

it took that which belonged to another, regarding it as its portion.

554 Each one took as his channel in the field [as his boundary mark] the appropriate furrow, sprinkled with the fluid of Pon Pirik-pirik.

555 To Tanaranga, so we are told, went on and on towards the East, Datu Muane walked constantly in the direction of the place where the shining one ascends.

556 Then, so we are told, a buffalo herdsman heard the divine progenitor of the pig coming forth out of the stone of basalt; thereon its glorious snout appeared,

then, so it is said, the ears of a herder of kerbau caught the sound of the squealing of the begetter, revered as a lord, of the swine, with neck hair suitable for the adat-performances, issuing out of the miraculous rock; thereon its golden hoof became visible.

557 He showed it to To Tanaranga, so we are told.

558 Then To Tanaranga took the divine progenitor of the pig out of the stone of basalt,

thereon Datu Muane grasped the begetter, revered as a lord, of the swine with neck hair suitable for the adat-performances.

5.59 And he made a roomy sty for it on four struts, he put up a large pen for it on poles, complete in number.

560 Then there came into being a huge family in the roomy sty, a quantity that multiplied, white spotted, like roasted rice grains, thereon it became a vast host, appearing like the white lees of palm wine.

561 Kambunolani' concluded a marriage with Kundailani', Ta'dun Kaissanan entered into a union with Datu Baine.

562 Pande Patanya' concluded a marriage with Kundaitetuk, he entered into a union with her.

563 Pande Palu concluded a marriage with Kundaibubun, Pande Nunu entered into a union in the Land of Illin. 
564 Iamo ußkande sesanna siulu'na, iamo untimbu' ra'dak barokona le'to lolona.

565 Rumampan ia kapa' tama padaß di Illin, sirampanan kapa' Tumba' Bollan, to ponto litakan, to gallaß karauan.

566 Dadimi anakna saßajoka tedoß, takkomi kamaseanna pa'sullean allo saßjbassean samban.

567 Kasalle dadinna, lobo' garaganna, umposaza saßanna, umpoganti pa'gantiananna.

568 Bunga'na disanami Datu Bakka', diganti Datu muane, ma'penduanna disanami Poß Malaleoß, diganti Datu muane.

569 La dibajuimi baju sielle'na patozkon a'pa', la didodoimi dodo saßkalamma'na lenton ganna' bilaßanna.

570 Alukna papa dirassa, beloß-belozanna tarampak ditonoranni.

571 Dilau' eranmi panalukanna patoßkon a'pa', dipasitaßke pelalanmi saßka' beloz-belozanna lentoz ganna' bilaßanna.

572 Dilando lalannimi tallaß ma'lampa rara', dilaka pa'taunanni ao' ma'buku bulaan.

573 Dilando lalannimi bane' sumomba matallo, dialami daun sumomba lu rekke.

574 Dilando lalannimi bolu kaju sitammu ura'na, dialami kalosi ponno issinna, kapu' ma'lumpa bumbußan.

575 Dilando lalannimi pusuk, dialami daun induk.

564 le'to lolona $=$ part of their umbilical cord; belonging to their umbilical cord, born of the same mother. In the Sanalla' territory, the term sile'to = brother, sister.

565 Armbands of clay and anklets of alloy are worn by women who have the status of slaves, see strophes 657 and 697 .

to gallan karauan $=$ he who wears an anklet of alloy.

$568 b a k k a^{\prime}=$ bewildered.

573 bane' sumomba matallo = the banana leaves that are pointed respectfully towards the East; these are the leaves upon which are placed the offering meal to the gods who reside in the North-East; the offering meal for the gods is laid down facing a north-easterly direction. 
$564 \mathrm{He}$ ate the rest of his brothers,

he partook of that which remained of the throats of the ones who were born of the same mother.

565 He concluded a marriage in the Land of Illin, he married Tumba' Bollan, the one who wore an armband of clay, the one who had an anklet of alloy as an ornament.

566 Then a set of children were born to them, thereon came into the world, as gifts of the union, a pair belonging together, like the ones over which the rope of the yoke is hung.

567 Then they reached maturity, their forms developed fully, each had his name, and each received his other name.

568 The first was called Datu Bakka', and his other name was Datu Muane, the second was named Pon Malaeon, and his other name was Datu Muane.

569 The four poles were to be clothed in the jackets befitting them, the supports, complete in number, were to be arrayed in the skirts suitable to them.

570 The offering rites for the closely-laid roof covering,

the required adat performances for the regularly placed edge of the roofing.

571 The acts of making the offering for the four poles were performed gradually, step by step,

the required adat performances for the supports, complete in number, were carried out, piece by piece, each following on the other, like the rungs of a ladder.

572 A long journey was made, in order to obtain the thin bamboo with the glorious internodes,

a distant tour was undertaken, lasting some seasons, with the object of acquiring the thick bamboo with the golden nodes.

573 A long journey was made, in order to fetch the banana leaves that point respectfully towards the East, the leaves were brought back which bend in reverence to the North.

574 A long journey was made, in order to obtain the betel leaves with the nerves that come together,

well-filled areca nuts were acquired, and lime, like bubbling cream on milk.

575 A long journey was made, in order to fetch the young unfolded leaves of the sugar palm,

the leaves of the sugar palm were brought back.

Verh. dl. 45 
576 Diosokmi osokan ozan, dipabendanmi kaju taß dipelolokki.

577 Dilando lalannimi sarita to lamban, dilaka pa'taunanni maa' to unnoron.

578 Dilando lalannimi gajaß ditarapani, dilaka pa'taunannimi kandaure salombe'.

579 Dilando lalannimi ianan sanda rupanna, dilaka pa'taunannimi baran apa mintu' sola nasan.

580 Randukmi disu'pi ampo anakna bai bu'tu ibatu, dialami mimi' kandaurena bonde ombo' rikumila'.

581 Dirarami patonkon a'pa', diterakmi lentoß ganna' bilazanna.

582 Sundunmi rekke lolokna alukna papa dirassa, upu'mi laßzan pendaunanna sazka' beloß-belonanna tarampak ditonoranni.

583 Apa barun-baruß maa'pa ade' tipamulanna lan taß̋ana lani', garu'ga' doti lani'pa lan una'na to palullußnan.

584 Umbaliaßzanmi ade' batu ba'tanna Puaß Matua lan taßzana lani', umbibi'mi karanan inaanna To Kaubanan lan masuazgana to paozanan.

585 Dilando lalannimi ade' Pande Pataßna', Pande Paita, dilaka pa'taunannimi Pande Manaraz, Pande Paliuk.

586 Lindomi sanda lindona Pande Manaran, Pande Paliuk, tasikmi batu rupanna Pande Paita, Pande Patanßa'.

585 pait $=$ seer; a person who can read all kinds of things from the constellations, who knows what the future will bring. In Buginese and Mamasaese, ita $=$ to see; in Sa'danese, it is kita.

586 lindomi sanda lindona $=$ the faces of all of them showed themselves. tasikmi batu rupanna = together their faces were like the sea. 
576 The fronds for shade were stuck in the ground, branches with the leaves on were set upright.

577 A long journey was made, in order to obtain the old long narrow blue woven cloth with the design of men fording a river,

a distant tour was undertaken, lasting some seasons, with the object of acquiring the old short wide fabric with the pattern of swimming men.

578 A long journey was made, in order to fetch the kris of great size,

a distant tour was undertaken, lasting some seasons, with the object of bringing back the piece of beadwork with the cords hanging low.

579 A long journey was made, in order to obtain precious things of all kinds,

a distant tour was undertaken, lasting some seasons, with the object of acquiring all the possessions together.

580 Then they took some of the progeny of the pig which had come forth out of the stone,

thereon they fetched the glorious offspring of the swine that had appeared out of the rock.

581 The four poles were then smeared with blood, the supports, complete in number, were then daubed with gore.

582 The offering rites for the closely-laid roof covering were completed, right to the top,

the required adat performances for the regularly placed edge of the roofing, were performed, to the highest one.

583 But at the start, so we are told, it was a booth of old short wide woven cloths that stood in the centre of the firmament,

it was, in the beginning, so it is said, a dwelling place covered with old short wide fabrics with a cross motif on them, that stood there in the zenith of the all-enfolding.

584 Then Puan Matua brought his innermost being into movement in the centre of the firmament,

thereon To Kaubanan brought the kernel of his inwardness into action in the highest part of the all-covering roof.

585 Then, so we are told, a long journey was made in order to summon Pande Patamna' and Pande Paita,

thereon a distant tour was undertaken, lasting some seasons, with the object of calling Pande Manaran and Pande Paliuk.

586 Then Pande Manaran and Pande Paliuk both appeared, thereon the forms of Pande Paita and Pande Patayna' came into view together. 
587 Ma'kadami Puan Matua kumua:

La ungaragaiki' banua bassi inde taßnana laßi', la umpabendanki' a'riri bonga ura'na lan una'na to palulluzan.

588 Dipabendanmi ade' banua bassi lan taß̧ana lani', dipatunannanmi ade' a'riri boßga ura'na lan una'na to palullußan.

589 Maßkami banua bassi lan taßzana laßi', sundunmi a'riri bonga ura'na lan una'na to palullußan.

590 Umpatuka'omi pa'ba'taßan Puaß Matua lan taß̧ana laßi', umpasolo'mi pa'inaan To Kaubanan lan masuaßgana to paoranan.

591 Diranteimi ade' buntu karua lan taßßana lazi', dilappa'imi tanete ganna' bilaßanna lan masuaßgana to paoßanan.

592 Dialammi kalo' daa mai ulunna lazi', ditebakammi palempan daa mai karopokna pandan matari' allo.

593 Marantemi buntu karua, lappa'mi tanete ganna' bilaßanna.

594 Kombonmi uma ma'kambuno lumu', marantemi panompok doke-dokean.

595 Disazami Tanduß Siulunna Lani', digantimi Minaza To Palulluzan.

596 Ditenkomi Tanduß Siulunna Laßi', dibatakannimi Minaza To Palulluzan.

597 Apa mennuaka'mi ade' tama Tandur Siulu sendana sugi', memparomponmi ade' tama Minaßa To Palullußan kaju mentaßke ianan.

598 Ussaßganmi ade' teßko bulaan uaka' barinni'na sendana sugi'. urrupukmi batakan rau-rau umparomponna kaju mentanke ianan.

599 Randukmi ade' diaßka' laßß̧an kalandona buntu nene' mendeatanna sendana sugi', tipamulannami ade' disakkaß laßzan patioranna tanete kaju mentaßke ianan.

592 dialammi $k a l 0^{\prime}=$ a ditch was led away. Among the South Toradja, the usual method of levelling a hillock is to direct a flow of water over it.

596 dibatakanan $=$ ditenko $=$ it was ploughed up.

597 memparompon $=$ to sit with the lower part in the ground.

598 umparomponna $=$ its sitting with its root stock in the ground. umparompon is an um-form used substantively; cp., strophe 604 . kalandona buntu $=$ the height of the mountain. 
587 Said Puan Matua:

"Let us build an iron house here, in the centre of the firmament,

let us erect the poles with strong fibres, here at the zenith of the all-enfolding."

588 Then, so we are told, the iron house was built in the centre of the firmament,

thereon, so it is said, the poles with strong fibres were erected at the zenith of the all-enfolding.

589 When the iron house in the centre of the firmament had been prepared, when the poles with strong fibres stood ready at the zenith of the all-enfolding,

590 Puan Matua let his thoughts rise on high in the centre of the firmament, To Kaubanan let the reflections in the highest part of the all-covering roof, sink down.

591 Then eight mountains in the centre of the firmament were made flat, thereon the hills, complete in number, in the highest part of the allcovering roof, were levelled out into a smooth terrain.

592 From the North, from the head of the firmament, a ditch was led away, from the upper part of that which lies stretched out, round, like the disc of the sun, a channel was dug.

593 Then the eight mountains were flattened, thereon the hills, complete in number, became level land.

594 A wet ricefield was created there, with duckweed as a sunshade, a dyked sawah was formed there, full of water plants, flat and level.

595 It was called, ,The field lying at the head of the firmament", its other name was "The water pool of the all-enfolding".

596 The field lying at the head of the firmament was ploughed up, furrows were made in The water pool of the all-enfolding.

597 Now, so we are told, the richly laden tjendana tree took root in The field lying at the head [of the firmament],

the tree whose branches are full of precious things, burrowed its roots into The water pool of the all-enfolding.

598 The fine roots of the richly laden tjendana tree damaged, so we are told, the golden plough,

the root stock of the tree whose branches are full of precious things, dented the pole of gold mixed with silver.

599 Then, so we are told, people set about taking the divine parent of the richly laden tjendana tree on high, to the top of the mountain, then, it was, so it is said, that they began to carry the tree whose pranches are full of precious things, to the crown of the hill. 
600 Apa taß kasallemi ade' dadinna dao kalandona buntu, tan lobo'mi garaganna dao patioranna mata tanete.

601 Ma'kadami ade' kumua:

Taß kasallemo dadinki inde kalandona buntu, tan lobo'mo garaganki inde patioranna tanete.

602 Nakua: Pasulemokan rokko tampona limbon, padionmokan tompokna minaza tua.

603 Kipoli'mora kaleki, andi' kilendu' tama uma ma'kambuno lumu' uaka' barinni'ki, tembomora malempaß tama panompok doke-dokean umparompoßki.

604 Namalolomora rokko maririnna litak uaka' barinni'ki, namalambu'mora rokko to kebali'bi' umparomponki.

605 Naolai kalimbuaß boba, napolalanni to' mata uai.

606 Pa iamo la susu mammi'na uma ma'kambuno lumu' tu kalimbuaß boba, iamo panoran kasallena panompok doke-dokean tu to' mata uai.

607 Kendekmi ade' burana Tandur Siulu, laßzanmi ade' lupa'na Minana To Palullußan.

608 Apa taß ponno suka'na ade' burana Tanduß Siulu, taß lempan kararona ade' lupa'na pananda uai.

609 Randukomi umbalianan batu ba'taßna Puaß Matua, dionomi umbi'bi' karaßan inaanna To Kaubanan.

610 Ullando lalanniomi bulaan matasak rokko kalambuan allo, ullaka pa'taunammi nane' taß karauan rokko kabotoan kulla'.

603 kipoli'mora kaleki $=$ we shall brush ourselves out of the way.

607 bura $=$ foam.

608 kararo $=$ coconut shell; used as a cubic measure for the measuring of dry commodities; and see 49 .

pananda $u a i=$ the regulator of the water; it is the poetical description of a flooded ricefield. 
600 But, so we are told, it did not take root on high, on the top of the mountain,

it did not develop well on the crown of the hill.

601 Then, so we are told, it said:

"I do not take root here on high, on the top of the mountain, my form does not develop well here, on the crown of the hill."

602 It said:

"Take us back to the dyke of the pool,

place us beneath it, on the sheet-pile of the old water pond."

603 "We shall stay there, out of the way, and take care that we do not allow our fine roots to go near the ricefield which has duckweed as a sunshade,

we will see that our root stock does not stray into the dyked sawah, full of water plants."

604 "Our fine roots shall go straight down into the yellow layer of the earth,

our root stock, without straying, shall go downwards into the underworld."

605 Then it took the unfailing well as its path, thereon its way became the welling-up spring.

606 The unfailing well, it will be the delicious breast for the wet ricefield, with duckweed as a sunshade, the welling-up spring shall be the great udder of the water-filled sawah, full of water plants.

607 Then, so we are told, the produce of The field lying at the head [of the firmament], sprang up,

thereon grew the harvest of The water pool of the all-enfolding.

608 But, so we are told, the produce of The field lying at the head [of the firmament], did not reach its full quantity,

the harvest of the richness of the sawah, dyked to keep the streaming water in bounds, was below its measure.

609 Then Puaß Matua again brought his innermost being into movement, To Kaubanan, there below, again brought the kernel of his inwardness into action.

610 He made a long journey to the place where the sun descends, in order to obtain the pure gold,

he undertook a distant tour, lasting some seasons, to the region where the shining one sinks down, with the object of acquiring the unalloyed gold. 
611 Naseno tingimi dion kalimbuan boba bulaan matasak, naembon pinamasak dioß to' mata uai nane' taß karauan.

612 Ponno sepu'nami Puan Matua bulaan matasak, lempan karopi'nami To Kaubanan nane' taß karauan.

613 Lumokkonmi lalanna, tumetemi ta'gulizanna.

614 Dibolloan barra'omi tama sauan sibarruß bulaan matasak, dibaku amboranomi tama sulin pada dua nane' taß karauan.

615 Dadiomi anakna sauan sibarruß saßajoka tedoß, takkomi kamaseanna sulin pada dua saßbassean samban.

616 Kasalle dadinna, lobo' garaganna, umposanami saßanna, umpogantimi pa'gantiananna.

617 Disanami Datu Meßkamma' misa', disaza Karaen Ma'loko-loko misa'.

618 Unkambirammi pemali sanda saratu' Tanduß siulu, unnizkorammi saßka' aluk penduan riu Minaßa to palullußan.

619 Ponno suka'nami pole burana Tanduß siulu, lempan kararonami lupa'na Minaza to palulluzan.

620 Iamo nene'na to ditanan indo' to'o, iamo to dolo kapuazanna to diranduk paßlaa padaß.

621 Umbaliaßammi batu ba'tanna Puan Matua lan taßßana lani', umbi'bi'mi karaßan inaanna To Kaubanan lan masuangana to paozanan. 
611 Then he sifted the pure gold, as though it were dark red beads, in the unfailing well,

thereon he washed the unalloyed gold, as if it were as precious as dark yellow beads, in the welling-up spring.

612 The sirih pouch of Puan Matua was full of the pure gold, the bag of To Kaubanan, made of the leaves of the sugar palm, was brimful with the unalloyed gold.

613 Then he retraced his way, thereon he went back along his path.

614 The pure gold was thrown, like unhusked rice, into the pair of bellows belonging together,

the unalloyed gold was poured, like seed, in great quantity, into the two blow pipes of equal size.

615 Again two children were born to the pair of bellows belonging together, thereon came into the world, the gifts of the union of the two blow pipes of equal size, a pair of children, well-shaped, belonging together, like the ones over which the rope of the yoke is hung.

616 They reached maturity, their forms developed fully, each had his name, and each received his other name.

617 The one was called Datu Menkamma', the other was named Karaen Ma'loko-loko.

618 They watched over the complete number of a hundred prohibitions for The field lying at the head [of the firmament],

they guarded the twice a hundred thousand ritual prescriptions for The water pool of the all-enfolding.

619 Then the produce of The field lying at the head [of the firmament], reached its full quantity,

thereon the harvest of The water pool of the all-enfolding overflowed its measure.

620 They are the ancestors of the ones who are placed as guardians over the soil,

they are the forefathers, revered as lords, of the ones who are set as keepers of the ground.

621 Puan Matua brought his innermost being into movement in the centre of the firmament,

To Kaubanan brought the kernel of his inwardness into action in the highest part of the all-covering roof. 
622 La dirundunan bulomo panalukanna banua bassi, dipasilau' eran, dipasitete malaa'mo saßka' beloß-belonanna a'riri boßga ura'na, dipasitaßke pelalan.

623 Randukomi disu'pi ampo anakna manuk, diala mimi' kandaurena raßka' dipeaßla'.

624 Randukomi disu'pi ampo anakna bai bu'tu ibatu, diala mimi' kandaurena bonde ombo' rikumila'.

625 Randukomi pole disu'pi ampo anakna tedon ma'butu aluk, diala mimi' kandaurena karambau massongo bisara.

626 Dilando lalannimi sarita to lamban, dilaka pa'taunannimi maa' to unnoron.

627 Dilando lalannimi gajaß ditarapani, dilaka pa'taunannimi kandaure salombe'.

628 Dilando lalannimi patoko ma'dandan, dilaka pa'taunannimi rara' tiku ikolloß.

629 Dilando lalannimi pole tallaß ma'lampa rara', dilaka pa'taunannimi ao' ma'buku bulaan.

630 Dilando lalannimi bane' sumomba matallo, dialami daun sumomba rekke.

631 Dilando lalannimi bolu kaju sitammu ura'na, dialami kalosi ponno issinna, kapu' ma'lumpa bumbuñan, tagari sazujun.

622 bulo $=$ thin bamboo; with long straight internodes.

dipasitanke pelalan $=$ it is held from one rung of the ladder to the other; dipasilau' eran $=$ it is done from one step to the other; it is done gradually. lau' eran $=$ step of a stair.

623 ranka' dipeanla' $=$ the feet that are examined with care; the scales on the feet of the fowls that are to be offered are examined to see if their form makes them a suitable offering. 
622 In order to perform the ritual for the iron house, from start to finish, step by step, in the right order,

with the object of effecting the required adat performances for the poles with strong fibres, in regular order,

following on each other, like the rungs of a ladder.

623 Then they again took some of the descendants of the fowl, thereon were fetched the illustrious family of the ones whose feet are carefully examined.

624 Then they again took some of the progeny of the pig which had come forth out of the stone,

thereon were fetched the glorious offspring of the swine that had appeared out of the rock.

625 Then they took some of the descendants of the buffalo with skin befitting the offering rites,

thereon were fetched the illustrious family of the kerbau with neck hair suitable for the adat performances.

626 Then a long journey was made, in order to fetch the old long narrow blue woven cloth with the design of men fording a river,

a distant tour was undertaken, lasting some seasons, with the object of bringing back the old short wide fabric with the pattern of swimming men.

627 A long journey was made, in order to obtain the gold kris of great size,

a distant tour was undertaken, lasting some seasons, with the object of acquiring the piece of beadwork with the cords hanging low.

6,28 Then a long journey was made, in order to fetch the gold covered beads strung in a row,

a distant tour was undertaken, lasting some seasons, with the object of bringing back the chain that circles the neck.

629 A long journey was also made, in order to obtain the thin bamboo with the glorious internodes,

a distant tour was also undertaken, lasting some seasons, with the object of acquiring the thick bamboo with the golden nodes.

630 A long journey was made, in order to fetch the banana leaves that point respectfully towards the East, and the leaves were brought back which bend in reverence to the North.

631 A long journey was made, in order to obtain the betel leaves with the nerves that come together,

well-filled areca nuts were acquired, and lime, like bubbling cream on milk, and bunches of fragrant grass. 
632 Dilando lalannimi bambalu todin, dilaka pa'taunannimi tualle samara.

633 Dilando lalannimi tallu basonna, dilaka pa'taunannimi pusuk.

634 Bendanmi osokan ozan, tunannaßmi kaju taß dipelolokki.

635 Tipandanmo laßzan, bendanmo ao' disulela.

636 Randukmi diboroßanni nene'na manuk, dionmi dikadaani to dolo kapuananna kanuku diarru'.

637 Ia lotoß, suru'na rampe matampu' dio to diponene', sipopatu patu boroßna, sipokalo' kalo' kadaaßna.

638 Ia karuruß, suru'na ma'bala tedoß, sara'ka'na ma'bonton karambau, sipopatu patu boronna, sipokalo' kalo' kadaanna.

639 Ia rame tasik, suru'na tetean tampo, ia sella' mabusa baba'na sikambi' kalandona buntu dio to ditanan indo'.

640 Ia koro, manukna to pekolon kuse, napoparamae lako tutunna lalan, ke den manuk-manuk nakamalini.

641 Ia uran-uran, suru'na kombon marapuan, ia bullau, iamo napopakuli ura' to makuju lankan.

642 Ia pute, iamo sirondon lumbaa laßi', ke bendanni paraßka dialuk.

635 lanzan is a kind of roasting spit consisting of a bar of wood or bamboo laid on small poles placed crosswise against each other.

640 manuk-manuk nakamalini $=$ they are perturbed because of the actions of the birds; bad omens are deduced from the flight of birds, or the sounds they make. 
632 A long journey was made, in order to fetch a thick liana with streaks on it,

a distant tour was undertaken, lasting some seasons, with the object of bringing back a kind of liana with long white stains.

633 A long journey was made, in order to obtain rattan, and the unfolded young leaves of the sugar palm were acquired.

634 Then the fronds for shade were stuck in the ground, branches with the leaves on were set upright.

635 Then the bar was stretched out on the small poles, thereon the pieces of thick bamboo, laid crosswise on each other, were set up.

636 And they allotted to the progenitors of the fowls the various adat performances in which they were to be used,

they assigned the proper tasks to the forefathers, revered as lords, of the ones whose claws are trimmed with a small knife.

637 The black fowl, it is the atonement offering for the West, for the ones who are regarded as ancestors,

it was duly assigned the charge proper to it,

it was allotted the task suitable to it.

638 The black fowl with white spots, it is the atonement offering for the stalling of the buffaloes, the cleansing offering for the stabling of the kerbau,

it was duly assigned the charge proper to it,

it was allotted the task suitable to it.

639 The yellow-brown fowl, it is the atonement offering for the cultivation of the ricefields,

the brown cock with a white tip on its ear lobes, is associated with the top of the mountain, and is offered by the ones who are appointed as leaders of the rice cultivation.

640 The white fowl flecked with black, it is the fowl for the ones who carry on their backs the skin of the marsupial, they always use it on their journey if they are perturbed by the behaviour of the birds.

641 The black fowl with white spots, it is the atonement offering for the plantation of the clan members,

the grey fowl, it is used as medicine for the muscles of the ones who are exhausted.

642 The white fowl, it is associated with the bamboo erected heavenwards, when the stake, at which the ritual is performed, is set upright. 
643 Ia buri', iamo napatakinni panampa to Darru', anak dipajuni napopanizoan, iamo dipaselle'i pa'kombon to Balanda dio anak dipajuni, napoparamae.

644 Randukomi diboronanni nene' mendeatanna bai bu'tu ibatu, dioßomi dikadaaßanni to dolo kapuaßanna bonde ombo' dikumila'.

645 Ia bai bu'tu ria mambu, ia bonde ombo' to' tille malulun,

646 tojaß ade' tondonnara lalan to'o, sambali' ade' mata kalambanan.

647 Apa la tojaßraka, nala pusa boronna, la sambalinraka, nala ompon kadaanna?

648 Ia ade' bai urrundu' paßkalo' puaß, ia ade' umpanlola baan pamuso' deata.

649 Iamo bai pebußkanan, iamo bonde pekarakkaß, tojaß tondonna lalan, sambali'na mata kalambanan.

650 Taß la kumpaß tama kapemalaran, taß la kumbaa' tama kapa'urande-randean.

651 Biasa ia nabusak to mendaun sugi', malute ia natapai to mentaßke ianan.

652 Ia bai bu'tu ibatu, iamo ia kumpan tama kapemalaran, ia bonde ombo' rikumila', iamo kumbaa' tama kapa'urande-randean.

653 Randukomi diborozanni nene'na tedoß, dioßmi dikadaananni to dolo kapuananna karambau.

646 The meaning of this strophe is that these pigs cannot be used for the offerings.

648 pamuso' $^{\prime}$ that which is shaken; i.e., the kapok from which the seeds are removed by shaking it.

"that agitated by the gods", and "the channel in the field dug by the lords", are the rivers which were dug by the gods.

"like a parakeet", refers to the habit of parakeets of flocking together.

$650 k u m b a^{\prime}=$ to swish to and fro; like the branch of a tree.

kapa'urande-randean here means the place where the gifts are offered on the flat of the hand; in strophe 48 the meaning is the holding of the gifts on the flat of the hand. 
643 The light-brown cock with white spots, it is the cock to which the young people of high rank attach that shaped by the people of Darru', in order to play,

that is the one to which the youths of exalted station fasten that made by the Dutch, with the object of enjoying themselves.

644 Then they allotted to the divine progenitor of the pig which had come forth out of the stone, the various adat performances in which it was to be used,

they assigned the proper task to the forefather, revered as a lord, of the swine that had appeared out of the rock.

645 The pig which comes out of the alay-alan grass, is black and woolly, the swine that comes forth from the reeds, is sway-backed.

646 It is, so we are told, far from the edge of the path, it stays, so it is said, on the opposite side of the main way.

647 But, because it is so far, would that which has been allotted to it be unfair?

Because it is on the opposite side, would that assignment be unjust?

648 The pig which, so we are told, follows the channel of the lords, that, so it is said, scours that shaken by the gods, like a parakeet.

649 That is the pig which always searches for crabs,

it is the swine that goes for crayfish,

it is far from the edge of the path,

it is on the opposite side of the main way.

650 It shall not turn aside to the offering places,

it shall not swerve aside to the places where the gifts to the gods are offered.

651 The ones whose wealth is as abundant as leaves, usually dry its flesh in the sun for meat,

the ones whose possessions are like the branches of the trees, have the skill to dry it over a fire.

652 The pig which came forth out of the stone, that is the one that turns aside to the offering place,

the swine that appeared out of the rock, that is the one which swerves aside to the place where the gifts to the gods are offered.

653 They also allotted to the progenitors of the buffaloes the various adat performances in which they were to be used,

they assigned the proper tasks to the forefathers, revered as lords, of the kerbau. 
654 Ia tanduk bibaß, iamo suru'na rampe matampu' dio to diponene', disankin bambalu tessek, dila'ka' tualle matua dio sendana donka.

655 Ia sambo ra'tuk, tedorna ia burake manakka, nasurusan bataß dikalena.

656 Ia tanduk tinke', tedonna to pedudur tanduk, karambaunna to perande salaßka', nasurusan bataß dikalena.

657 Ia sambao', iamo tedonna to ponto litakan, natidakan bataß dikalena, anna dundu pindan, nairu'i suke bulaan, nasule sazsali sonle' lazi' kalua'na.

658 Ia todi, tedonna datu Itan diPalopo, nasurusan bataß dikalena.

659 Ia boßa tasak, tedonna puaß, nasurusan bataß dikalena, sirondon sendana lalon dion rampe matampu', sirondor sendana bora lan rampe matallo.

660 Ia pundu paresa', tedonna to kandean bassi, ia tedon ma'lila tabaß.

654 This buffalo is slaughtered at the ma'tomatua or ma'nene', or maneka', the offering to the ancestors taken to the neighbourhood of the rock grave.

655 burake: priestess who officiates at the $l a^{\prime} p a^{\prime}$ feast.

In the Western territories, it is the women who fill this priestly office, the succession being hereditary.

In some territories in the east, male hermaphrodites who are 'possessed' clothe themselves in women's clothes and then act as burake; see "De Toradja's van de Sa'dan-, Masuppu'- en Mamasa-rivieren", T.B.G. LXIII, Part 2, pp. 391-401. It is a privilege of the burake that such a white spotted buffalo is offered when she holds the merok feast.

sambo $r a^{\prime} t u k=$ covered with roasted rice grains; as they burst open the white inner part becomes visible.

656 tinke': round thin wooden splints on the spinning wheel; these enable the threads of cotton to be properly twisted together.

"the ones who wear horns on their heads", are the to menani=leaders at the $l a^{\prime} p a^{\prime}$ padar feast and also of the song accompanying the feast which is held to ensure a fruitful harvest. The horns worn by the to menani on their heads are made of the ribs of the leaves of the sugar palm. These horns are mockingly referred to as tanduk pesanle bai=horns like the scoops with which the pigs' food is ladled out, because they are notched like the scoop.

The basket in which to catch fish is called salakka' and da'dak. It has a small neck and widens towards the bottom.

At the $l a^{\prime} p a^{\prime}$ padan feast, the offering gifts of one of the offerings are laid on this basket by the to menani.

657 sansali sonle' lani' kalua'na = having the same elevated floor of their wide sky, i.e., of their masters.

"they use it as the offering animal for themselves", = to buy themselves out of slavery; this adat performance is called ma'talla'. It required that buffaloes, pigs, eating dishes and other objects, totalling 100, must be offered. The figure of 100 
654 The ones which have horns like a splinter from a cooking pot, they are the atonement offering for the West, for the ones who are revered as ancestors,

they are bound with an old liana, they are fastened by an old thin climbing plant to the tjendana tree whose heartwood has green spots.

655 The buffalo with white patches, it is the buffalo for the skillful burake, they use it for the offerings for themselves.

656 The one with thin horns, it is the buffalo for the ones who wear horns on their heads,

the kerbau for the ones who hold on their palms the basket in which to catch fish,

they use it for the offerings for themselves.

657 The grey buffalo, it is the buffalo for the ones who wear an armband of clay,

they use it as the offering animal for themselves,

so that they can eat out of the same dish, and drink out of the small golden containers; so that they can revert to being on the same elevated level as the wide sky.

658 The buffalo with the white patch on its head, it is the buffalo of Datu Itan in Palopo,

he uses it as the offering for himself.

659 The buffalo with a completely white patch on the head, it is the buffalo of the puan, he uses it as the offering for himself,

it stands by the big tjendana tree in the West,

it is placed beside the white spotted tjendana in the East.

660 The buffalo with short blunt horns, it is the buffalo for the ones who were nourishment for the iron,

it is the kerbau of the ones whose tongues were a leaf of the dragon's

blood plant.

was symbolic; usually 6-10 buffaloes and pigs were offered. The freedman could then eat out of the same dishes as his ex-master and drink out of the same drinking utensils. The ma'talla' could only be effected by a freeman of pure blood or of mixed blood who had become a slave. Hence the reference in this strophe to reverting to the same elevated status, being like the wide sky. $d u n d u=$ to hold to the mouth.

659 The most valuable buffalo is one with a completely white patch on its head.

660 paresa', I could not get an explanation of this word.

"the ones who were nourishment for the iron", are people killed in battle by the spear or the sword. "the ones whose tongues were a dragon's blood leaf", are people out of whose mouths blood has flowed.

Verh. dl. 45 
661 Disankin lako simbuan lazsa' lan rante kalua'.

662 Nasisimboni to panoto ba'taß lan rante kalua', nasibaen-baenanni to disedanan gandaß paranka sadarna lan tanduß kalonaran.

663 Anna tibunka' mata bubunna to kandean bassi, natikillan tondon turunanna to timbusan mata pinai.

664 Ia taranga masiak, disankin lako simbuan induk lan rante kalua', ke den to mendaun sugi' nalambi' sumpu matua.

665 Iamo ia dila'ka' lako lambiri tessek, ke den to mentanke ianan nadete' banu' karuruzan.

666 Apa sundunmo kupasipatu patu boronna, upu'mo kupasikalo'-kalo' kadaanna.

667 Apa den manii kupasibekoan, den manii kupasikairian.

668 Den manii dolona kupaundinna, den manii undinna kupadolona.

669 Kamupi Puan Matua, la kubuani sanda randanna la umpasirundunan buloi, kamupa To Kaubanan, la kupa'kolakanni sanda birinna la umpasitete malaa'i.

661 The planting of a lansat tree near the great stone at the place where the buffaloes are slaughtered, was part of the ritual for the dead man when he had been killed in battle.

The laysa' (Lansium domesticum) is the same as the Indonesian laysat or laysap tree; it has small yellow fruit.

662 When a member of a clan has been killed in battle, his fellow clan members improvise strophes of a sarcastic and derogatory nature about his slayer, which they recite to the buffalo that is to be slaughtered. These strophes contain a prayer that the death of the slain man may be speedily avenged.

simbon is the name usually given to the chorus which is sung at the $l a^{\prime} p a^{\prime}$ feast, and at the great maro feast.

"the ones in whose jaws a drum hangs", are people who are skilled in speaking. Gandan = drum; it is the figurative description of the to minaa $=$ those who know the offering ritual and can recite the offering prayers.

paranka $=$ forked branch $;$ paranka sadan = the forked branch of the mouth.

When the song is transmitted, the second to minaa gives the explanation of the improvisation spoken by the first to minaa.

663 Owing to the magical influence that emanates from a person who has been killed in battle, his well is under the control of the death-sphere and is, as it were, tightly shut. Both these parallels express the desire that the slain man may be speedily avenged and the control of the death-sphere removed. Before a slain person has been avenged the death ritual cannot be held. 
661 It is bound to the great stone, at the side of which a lansat tree is planted on the great field.

662 To it, the ones on the wide field whose spirits can touch the heart, recite in turn diverse derogatory strophes, speaking to it, the ones on the broad plain in whose jaws a drum hangs, pass the song to each other.

663 So that the mouth of the spring of the nourishment of the iron, may be opened,

in order that the rim of the well of the food of the blade of the sword, may be cut open.

664 The impetuous buffalo, with the upward curving horns, it is the one that is bound to the trunk of the sugar palm on the wide plain, when the one who is as rich as the leaves, has passed the outermost point of his life.

665 It is the buffalo that is bound to the very old sugar palm of the monkeys, when the one whose possessions are like the branches of the tree, has arrived at the ultimate point of his life, durable as the hard heartwood of the sugar palm.

666 Now have I finished allocating to each one of them the charge proper to it,

I have now come to the end of assigning to each one the task suitable to it.

667 Perchance I have been at fault regarding the mutual relationships, mayhap I have been incorrect in respect of the mutual connections.

668 It may be that I have mentioned last the one who should be first, it may be that I have said first the one who should be last.

669 Let me then surrender it to thee, Puaß Matua, from the beginning to the end, so that thou canst put it in order in the proper manner, let me cast it before thee, To Kaubanan, from start to finish, in order that thou mayest arrange everything in the right way.

664 simbuan: that which is set up for the purpose of tying up the buffaloes which are to be slaughtered at the death feast; the simbuan batu are the great monoliths erected for a deceased person of high rank. Small tree trunks are set in the ground beside these monoliths and the buffaloes are tied to them; for example, simbuan kalosi $=$ consisting of the trunk of an areca palm.

"the wide plain", is the place of the feast where the second part of the death feast is held and where the buffaloes are slaughtered. 
670 Ia ia uainna bulu riri, iamo mimi'na pate bulunna.

671 Iamo tedon ma'bulu aluk, iamo karambau massongo bisara,

672 iamo natekkenan doke Kambunolani', ma'tali maa', bendan petoei soßkanß.

673 Iamo nakaßkanan induk disila bannaß Ta'duß Kaissanan tunannaß, ma'tompu masura' pedeken panaaran.

674 Dirarami rara tallu banua bassi, apa lamba'pa ade' dinii ussaßkin tedon ma'bulu aluk, kaju ma'lite bumbunanpa ade' dinii ulla'ka' karambau massongo bisara.

675 Sundunmi rekke lolokna alukna papa dirassa, upu'mi rekke pendaunanna saßka' beloß-beloßanna tarampak ditonoranni.

676 Matoro pondokmi Datu Bakka', moka pesembaß laßßan, mauataß kaju boko'mi Poß Malaleoß, taß ma'din peosok oßan.

677 La rumampanni kapa' lako sanserekanna, la umpakulea'mi pa'sullean allo lako saßpa'duananna.

678 Nokami sanserekanna, taß ma'dinmi saßpa'duananna.

679 Ma'kadami Datu Bakka' kumua:

Ma'apai munoka kurampanni kapa', nasantibussanan nene' mendeatanta lanmai sauan sibarruß?

680 Ma'tundu malesomi Pon Malaleon kumua:

Tumba mutaß ma'din kupakulea'i pa'sullean allo, nasanpetaunian to dolo kapuaßanta lanmai sulin pada dua?

670 The buffalo with a yellow skin is the buffalo that is consecrated and offered at the merok feast.

The word pate could not be explained to me. I have read the word pati' for it and have used it in the translation.

674 "the blood of the trinity", is the blood of the fowl, the pig and the buffalo. At the merok feast held on earth, the buffalo is tied to a tjendana tree of which the sap is red.

676 Datu Bakka': the ancestor of slaves; he was born of slaves. The bristles of the pig that has been slaughtered as the offering animal are burned on the roasting spit mentioned in this strophe. This task, like sticking the palm fronds for shade in the ground, is work for slaves.

677 "group members" in this instance means someone who is descended from the same ancestor, who came forth from the pair of bellows belonging together, with the ancestor of Datu Bakka'. 
670 The one then that was the descendant of the yellow-haired one, the one that was the progeny of the one whose skin was well-proportioned.

671 The buffalo with skin befitting the offering rites, the kerbau with hair suitable for the adat performances.

672 That is the one before which Kambunolani', placed himself, holding the shaft of the lance,

wearing as a head cloth an old short wide woven cloth, a bamboo container in his hand.

673 That is the one in front of which Ta'dun Kaissanan drew himself up, holding in his hand the wood of the sugar palm, cleft along the prescribed line,

with a band, decorated with a design, on his head, grasping a small bamboo container.

674 The iron house was smeared with the blood of the trinity, but, so we are told, it was at that time a fig tree to which the buffalo with skin befitting the offering rites, was bound,

it was then, so it is said, the tree with sap white as milk, to which the kerbau with neck hair suitable for the adat performances, was tied.

675 The offering rites for the closely-laid roof covering were completed, right to the top,

the required adat performances for the regularly laid edge of the roofing were brought to an end, to the highest one.

676 Then Datu Bakka' stiffened his back, and would not hack down the bamboo for the roasting spit,

then the backbone of Pon Malaleon was unbending, and he would not stick in the ground the fronds for shade.

677 They desired to conclude a marriage with their group members, they wished to enter into a union with the ones with whom they were bound in one community.

678 Their group members did not wish to do so, the ones with whom they were bound in one community, refused.

679 Then said Datu Bakka':

"Why dost thou not wish that I conclude a marriage with thee, for our divine forefathers came into the world together, out of the pair of bellows belonging together?"

680 Then Poß Malaleon spoke, loud and clear:

"Why is it that thou refusest that I should enter into a union with thee, for the placenta of our forefathers, revered as lords, came forth from the same pair of blow pipes of equal size?" 
681 Ma'kadami saßserekanna kumua:

Tozan ia nasantibussanan to dolo kapuananta lanmai sulin pada dua, apa ma'lalan ba'taß iko to dolo kapuaßammu.

682 Rumampan kapa' tama padaß di Illin, urrampanni kapa' to ponto litakan, sipakuleasan pa'sullean allo to gallaß karauan.

683 Nokami dipotedoß tedon uma Datu Bakka', tan ma'dinmi dipokarambau tempe' Pon Malaleon.

684 Dioß bangmo ia matoro pondok, nenne'mo ia mauataß kaju boko'.

685 Bendanmi tarian pempitu lan taßßana lani', tunannazmi pandan dipamaroson lan una'na to paonanan.

686 Siukkunan, ditalo Datu Bakka' sola Poß Malaleon, taß nasana duka, sipakoko, ditalo Datu Bakka' sola Pon Malaleoß, taß nasana.

687 Dipato'doi uai, ditalo, taß nasana, dipadioan bamba masinki', taß nasana.

688 Silondonan, ditalo, taß nasaßa, randukmi dipa'paran tekken to ditanan gulin.

689 Bendanmi tutußan dama', tunannazmi tendanan ma'lana-lana.

690 Buntu sitarru'mi sulle to gandaß, gulinmi Tarasu iLaßi'.

691 Siparakusammi allo melambi' lan kapararian.

683 This strophe says that Datu Bakka' and Pon Malaleon would not do the work of slaves.

685 The sevenfold rules contained the regulations concerning the six trials which constituted the ordeal. In not accepting the result of the trials, the judgement hat to be determined by the final trial - war. In olden times, these trials were not infrequent.

687 dipadioan bamba masinki' $=$ a strict condition was placed upon them; i.e., a very severe oath was laid upon them whereby they had to swear, pointing to their throats as they did so, and if they spoke an untruth, their breath would choke them. The proof of the trial by spilling water onto the palms of each of the parties seeking justice, was that right was on the side of the one whose hand remained dry.

689 The lighting of the torch of resin was taken as a signal that war would break out.

690 "Then the deputy of the to minaa, like a mountain, came between them", refers to the intermediary who intervenes in the quarrel and who has contact with each of the parties. 
681 Then said the group members:

"It is true that our forefathers, revered as lords, came forth trom the pair of blow pipes of equal size,

but thou, thy forefather, revered as a lord, went his own way when he concluded a marriage."

682 "He went into the Land of Illin and concluded a marriage with one who wore an armband of clay,

he entered into a union with one who had an anklet of alloy as an ornament."

683 Datu Bakka' would not be treated like a buffalo used for work on the ricefield,

Pon Malaleon refused to be handled like a kerbau used for labour on the sawah.

684 He remained there, sitting, his back stiff, he stayed there, his back unbending.

685 Then a sevenfold decree was pronounced, in the centre of the firmament, thereon was it affirmed in a solemn pronouncement, in the highest part of the all-covering roof.

686 Then they performed the ordeal of diving, with their opponents, Datu Bakka' and Pon Malaleon were defeated, but they did not acknowledge it, thereon they stuck their hands in boiling water, with their adversaries, Datu Bakka' and Pon Malaleon were vanquished, but they did not accept it.

687 Then water was poured into their hands; they were defeated, but they did not acknowledge it,

thereon the most severe oath was laid upon them; they did not accept it.

688 Cocks were set fighting against each other;

they were defeated, but they did not acknowledge it,

thereon the staff of the one who acted as an intermediary was flattened for them.

689 Then the torch of resin was taken up to be kindled,

thereon the container with the high-flaming gum, to be held aslant, came into being.

690 Then the deputy to minaa, like a mountain, came between them, thereon Tarasu iLani' went to mediate.

691 Then the morning of the battle was decided upon. 
692 Dialami lan allo melambi' tinaunna Datu Bakka' sola Poß Malaleoß, dirintakmi lan kulla' kamammuran.

693 Naballakmi Tarasu iLani' sanda salunna, nasareseimi ta'pa' malesona.

694 Lumbanmi pole lan ta'ka' Datu Bakka' sola Pon Malaleoß, dipotedoß tedon uma, dipokarambau tempe'.

695 Umbaliaßanomi batu ba'taßna Puaß Matua lan taßnana lani', umbibi'mi karaßan inaanna To Kaubanan lan masuangana to paozanan.

696 Belanna tae'mo la narampanni kapa' Datu Bakka', taß denmo la napakulea'i pa'sullean allo Poß Malaleon.

697 Ungaragami tau-tau litak Puaß Matua lan taßnana laßi', untampami Potto Kalembaß To Kaubanan lan masuaßgana to paozanan.

698 Apa baßunmi taß ma'kada-kada tau-tau litak, dionmi taß ma'ulelean Potto Kalembaß

699 Undurukmi manuk-manuk lan taßßana lani’ Puaß Matua, umpasirampunmi garente-garente lan masuangana to paozanan To Kaubanan.

700 Ma'kadami manuk-manuk kumua:

Apamo te ba'ba salaki, anki dirampunmo lan taßßana laßi'?

Ma'tundu malesomi garente-garente kumua:

Tiapamo te kikamalini, Puaß, anki didurukmo garente-garente lan una'na to palulluran?

701 Ma'kadami Puaß Matua kumua:

Tae'ra to mukamalini.

Ma'tundu malesomi To Kaubanan kumua.

Taß denda to mukatumanai.

693 naballak $=$ he cut open.

697 Potto Kalemban = He Whose Armband Is of Clay; to ponto litakan = he who wears an armband of clay. This is the poetical description of slaves, see 568 and strophe 657 .

699 garente-garente $=$ to make trilling, piercing, scraping sounds; in this strophe it is the parallel of manuk-manuk= birds. 
692 In the early morning, the men of Datu Bakka' and Poß Malaleon were fallen upon,

at the time of the day when men are touched by warmth, they were severely wounded.

693 Tarasu iLani' decided entirely according to what was right, he testified to that which was clearly and distinctly the truth.

694 Then Datu Bakka' and Pon Malaleon, completely exhausted, bowed their bodies,

thereon they were treated like buffaloes used for work on the ricefields, they were handled like kerbau used for labour on the sawahs.

695 Then Puay Matua brought his innermost being into movement in the centre of the firmament,

thereon To Kaubanan brought the kernel of his inwardness into action in the highest part of the all-covering roof.

696 Because there was no one there with whom Datu Bakka' could conclude a marriage,

for there was nobody there with whom Pon Maleleon could enter into a union.

697 Puan Matua fashioned a puppet of clay in the centre of the firmament, To Kaubanan created Potto Kalemban in the highest part of the all-covering roof.

698 But the puppet of clay stood there, without speaking,

Potto Kalembay was there, without saying anything.

699 Then Puan Matua collected together the birds in the centre of the firmament,

thereon To Kaubanan gathered together trilling songsters, in the highest part of the all-covering roof.

700 Then said the birds:

"What offence have we committed that we have been collected together in the centre of the firmament?"

Thereon spoke the trilling songsters, loud and clear:

"In what way have we offended, Lord, that we trilling songsters have been gathered together in the zenith of the all-enfolding?"

701 Then said Puan Matua:

"There is nothing in which thou hast offended."

Thereon spoke To Kaubanan, loud and clear:

"There is nothing about which thou needst be dismayed." 
702 Apa ungaragara' tau-tau litak, nabaßun ia taß ma'kada-kada, untampera' Potto Kalembaß nadion taß ma'ulelean.

703 La milando lalananna' datunna anin dio randanna lanji' dao kalandona buntu',

la milaka pa'taunananna' ma'dika darindin dio lelean uran dao lajukna tanete.

704 Ma'kadami manuk-manuk kumua:

Tae' kibelai, Puaß.

Ma'kadami manuk-manuk kumua:

Sanadi ke kalumpini' rante, boko' ia ke pirik kaaßlean, nalambi' ia tu randanna lani', nadete' ia tu lelean uran.

705 Malemi kalumpini' rante lako randanna lani', diomi lelean uran pirik kaaßlean.

706 Kammami la santaun barri dio randanna lazi', dionmi la sanpealloan dio lelean uran, tae' sia la naalanna datunna anin.

707 Digaragammi pole bunde papurru' lan taßßana laßi', diananan dalla' paimbakan lan una'na to paozanan.

708 Ditanannimi bunde papurru' dao kalandona buntu dio randanna lani', dirandukkimi dalla' paimbakan dao patioranna tanete dio lelean uran.

709 Timummu'mi datunna anin tama bunde papurru', tidukunmi tama dalla' paimbakan ma'dika darindin.

710 Ma'kadami datunna anin kumua:

Apamo te ba'ba salaki, ammi tanannikan bunde papurru', kalumpini' rante, tiapamo te kikatumaßai, ammi randukkikan dalla' paimbakan, pirik kaaßlean?

704 kalumpini' rante: a swallow with a yellow breast which builds its nest in all kinds of places.

706 barri': a kind of red rice; taun barri' = the agricultural year, the time elapsing between the very first start of the work of cultivating the rice and the final rites for the rice after the harvest. The usual term for the agricultural year is taun pare.

707 tipurru' $=$ to be caught in a knot; purrusan = a sack which is closed by pulling a drawstring.

709 timummu' $=$ to go into something with a crowd. 
702 "But I have fashioned a puppet of clay which stands upright, without speaking.

I have created Potto Kalemban, and she is there, without saying anything."

703 "Wilt thou make a long journey for me, in order to seek the Prince of the Wind at the edge of the firmament, at the top of the mountain?"

"Wilt thou now undertake a distant tour, lasting some seasons, for me, with the object of searching for the Lord of Coolness, on the crown of the hill at the place from whence the rain moves?"

704 Then said the birds:

"That we cannot do, Lord."

The birds spoke:

"Except the swallow of the fields, except the bird of the high part that reaches right to the edge of the firmament, that goes right to the place from whence the rain moves."

705 Then the swallow of the field went to the edge of the firmament, the bird of the high part was at the place from whence the rain moves.

706 For almost a rice-year it was at the edge of the firmament, it was for a period of the dry season at the place from whence the rain moves, but it could not seize the Prince of the Wind.

707 Then, in order to catch him, a landing net, which could be drawn in tightly, was made in the centre of the firmament,

thereon a casting net, which could catch many, was woven, with the object of trapping him in the highest part of the all-covering roof.

708 Then, the landing net, which could be drawn in tightly, was placed on the top of the mountain at the edge of the firmament, thereon the casting net, which could catch many, was put on the crown of the hill, at the place from whence the rain moves.

709 Then the host of the Prince of the Wind went into the landing net which could be drawn in tightly,

thereon the group of the Lord of Coolness entered the casting net which could catch many.

710 Then said the Prince of the Wind:

"What offence have we committed, swallow of the field, that thou hast placed for us a landing net which can be drawn in tightly?" "What frightful things have we done, bird of the high part, that thou hast put for us a casting net which can catch many?" 
711 Ma'kadami kalumpini' rante kumua:

Tae' kami nakami ma'lalan ba'taß.

Ma'tundu malesomi pirik kaaßlean kumua:

Tae' kami nakami ma'tutu inaa.

712 Puaß Matua kami umpatudukan lalan,

To Kaubanan kami umpatetekan mata kalambanan.

713 Dakopa kamu misitiro lindo Puaß Matua, dakopa kamu misitontonan rupa To Kaubanan.

714 Rampomi lan taßnana lazi' datunna aßin sola kalumpini' rante, tidukunmi lan masuangana to paonanan ma'dika darindin sola pirik kaaßlean.

715 Ma'kadami datunna anin kumua:

Apa te kikamalini, kiditananni bunde papurru' dao kalandona buntu, tiapara te ba'ba salaki, kidirandukki dalla' paimbakan dao patioranna tanete?

716 Ma'kadami Puaß Matua kumua:

Tae'ra te mukamalini.

Ma'tundu malesomi To Kaubanan kumua:

Taß denda to ba'ba salamu.

717 Apa ußgaragara' tau-tau litak, nabaßun taß ma'kada-kada, untampera' Potto Kalembaß, nadion taß ma'ulelean.

718 La kupalendu'ko tama batan dikalena tau-tau litak, la kupatinumbuko tama tondon to batanna Potto Kalembaß.

719 Ma'kadami datunna anin kumua:

Nokakan kami lendu' tama bataß dikalena tau-tau litak.

Ma'tundu malesomi ma'dika darindin kumua:

Taß ma'dinkan kami la tinumbu tama tondon to bataßna Potto

Kalemban.

720 Apa nokakan kami la kandean ulli', taß ma'dinkan kami la pintokan olaß-olaß.

721 Ma'kadami Puaß Matua kumua:

Taindo' basse kasalle.

Ma'tundu maleso To Kaubanan kumua:

Taambe' pandan dipamaroson.

722 Diindo'mi basse kasalle, diambe' pandan dipamaroson, kumua:

$718 k u$ patinumbuko $=$ I make thee push towards; I make thee touch.

721 taindo' $^{\prime}=$ we care for as a mother, we answer for as a mother. taambe $^{\prime}=$ we care for as a father, we answer for as a father. 
711 Then said the swallow of the field:

"We are not the one in whose innermost being it arose."

Thereon spoke the bird of the high part, loud and clear:

"We are not the one whose heart had the thought."

712 "Puan Matua showed us the way,

To Kaubanan directed us on the path."

713 "Presently thou goest to meet Puan Matua, soon thou goest to see To Kaubanan."

714 "Thereupon, the Prince of the Wind and the swallow of the field reached the centre of the firmament,

thereon the Lord of Coolness and the bird of the high part arrived at the highest part of the all-covering roof.

715 Then said the Prince of the Wind:

"In what way have we misbehaved that a landing net, which can be drawn in tightly, was placed for us on the top of the mountain,

in what way have we offended, that a casting net, which can catch many, was put for us on the crown of the hill?"

716 Then said Puan Matua:

"Thou hast not misbehaved."

Thereon spoke To Kaubanan, loud and clear:

"Thou hast committed no offence."

717 "But I have fashioned a puppet of clay, which stands there upright, without speaking,

I have created Potto Kalemban, who is there, without saying anything."

718 "I desire thee to pass into the body of the puppet of clay,

I wish thee to enter into the form of Potto Kalemban."

719 Then said the Prince of the Wind:

"We do not wish to pass into the body of the puppet of clay."

Thereon spoke the Lord of Coolness, loud and clear:

"We refuse to enter into the form of Potto Kalemban."

720 "We do not wish to become food for the worms, we refuse to be pecked at by repulsive birds."

721 Then said Puan Matua:

"We take a severe oath upon ourselves."

Thereon declared To Kaubanan, loud and clear:

"We vouch for a solemnly sworn avowal."

72.2 Then the responsibility for the severe oath was assumed, thereon the solemnly sworn avowal was vouched for, as follows: 
723 Ianna lambi'i sumpu suka'na, tassu'ko laßßan botto ulunna tau-tau litak, mumale sola sanserekammu lako randanna lani' dao kalandona buntu.

724 Ianna dete'i tandan garaganna, tileakko laßßan passaroß̧anna, mutibalik lako lelean uran sola sanpa'duanammu dao patioran tanete.

725 Lumbaßmo pole lan ta'ka' Datu Bakka' sola Poß Malaleoß, dipopepandanan laßnan, dipopeosok oßan.

726 Narandanomi saki unnaßga' Bannobulaan lan taßßßana lazi', nabirinmi rammun ma'posana-sana Datu baine lan masuaßzana to paozanan.

727 Umbaliaßanomi batu ba'tanna Puaß Matua, umbibi' karanan inaanna To Kaubanan lan una'na to palullußan.

728 Dilando lalannimi Indo' Belo Tumbaß rekke ulunna lazi', dilaßka mambelami Indo' Bußa Sampa' rekke karopokna pandan matari' allo.

$729 \mathrm{~Pa}$ ia sikambi' pedampi to tian, ia siinko' petamba' to lakaan.

730 Umpatianka'mi bate lentekna Indo' Belo Tumbaß sibaa pedampi ma'burra, umpatirimbami pessoenanna Indo' Bußa Sampa' sikaloli' tamba' ma'pakuli-kuli.

731 Rampomi lan taßßana lazi' Indo' Belo Tumbaß, tidukunmi lan masungana to paoßanan Indo' Bußa Sampa'.

732 Ma'paßan-paßanmi sola Puaß Matua, Puaß Bassi-bassian, Puaß Ambo-amboan, sundunmi ma'paßan-paßan, upu'mi ma'damerak-merak, ma'kadami Indo' Belo Tumban kumua:

724 garagan = manufactured article, build, form. passarozan = that part of the head covered by the sun hat.

725 "the spit for their lords", is the roasting spit on which the bristles of the pig to be offered by their lords, are to be burnt.

726 saki unnanga' $=$ sickness that deliberately attacks a person.

728 Indo' Belo Tumbaß $=$ Mother Ornament of People in a State of Trance. Indo' Buna Sampa' = Benevolent Mother Blossom.

729 petamba $^{\prime}=$ styptic ; in this context it is used as the parallel of pedampi= medicine.

lakaan: I could not get an explanation of this word; it is translated as the parallel of to tian $=$ the ones who are treated at the maro rites.

$730 m a^{\prime} b u r r a=$ spitting. At the maro feast the sick are spat upon by the physician, the to ma'dampi, beaten with flames and subjected to the magical power of iron. 
723 "When she reaches the end of her span of life, then thou shalt go upwards, out of the crown of the head of the puppet of clay, and take thy departure, with thy group members, to the edge of the firmament at the top of the mountain.

724 "When she comes to the absolute point of her physical life, then shalt thou rise up, out of her skull,

and return to the crown of the hill, to the place from whence the rain moves, with the ones with whom thou art bound in one community."

725 Then Datu Bakka' and Pon Malaleon were bowed, they lay themselves down in complete submission, they were ordered to set up the roasting spit [for their lords], they were commanded to stick in the ground the fronds for shade.

i26 Then the plague of sickness attacked Banno Bulaan in the centre of the firmament,

thereon a disease, increasing in violence, ravaged Datu Baine in the highest part of the all-covering roof.

727 Then Puan Matua brought his innermost being into movement, thereon To Kaubanan brought the kernel of his inwardness into action in the zenith of the all-enfolding.

728 Then someone was sent on a long journey to the head of the firmament, in order to call Indo' Belo Tumbaß,

thereon somebody was despatched on a distant tour, to the North, to the upper part of that which lies stretched out, round, like the disc of the sun, with the object of summoning Indo' Buma Sampa'.

729 Because she is the guardian of the medicine for the ones who are treated at the maro rites,

she is the one who looks after the remedies for the ones for whom the maro feast is held, in order to cure them.

730 Then Indo' Belo Tumban rose to her feet, taking with her the medicine that is spat upon people,

thereon Indo' Buma Sampa' swung her arms, carrying with her the remedy that brings recovery.

731 Indo' Belo Tumban reached the centre of the firmament,

Indo' Buma Sampa' arrived at the highest part of the all-covering roof.

732 Then they chewed the betel quid with Puan Matua, Puan Bassi-bassian

and Puan Ambo-amboan,

after they had chewed the betel quid,

when they had finished making their mouths red,

Indo' Belo Tumbaß said: 
733 Indomokan sibaa pedampi ma'burra, apa pusa' te batu ba'tanki, Puaß, kalili karanan inaanki.

734 Sitintikan unnola parala' tamman, diozkan la umpolalan to' kurra manapa'.

735 Tae' nalo'ban lalan kipolalan, tae' namaindan mata kalambanan kipokalambanan.

736 Ma'kadami Puan Matua kumua: Umba nakita batu ba'tanmu, Indo' Belo Tumbaß, tiapa natontoni karaßan inaammu, Indo' Bußa Sampa'?

737 Nakua: Lando lalanniri Kambunolani', laka pa'taunanni Ta'duß Kaissanan.

738 Anna kendek disondoß inde banua bassi tumanke suru' ma'reboran didi, anna lanßzan dipalanta' inde a'riri bonga ura'na tumetaß lindo sara'ka' ma'serekan tuju rante.

739 Randukmi sapean tabaß lan banua bassi, tipamulannami rabekan tanke lassigi lan a'riri bonga ura'na.

740 Umpale'ke'mi pedampi ma'burra Indo' Belo Tumbaß, umpalakomi tamba' ma'pakuli-kuli Indo' Bura Sampa'.

741 Kendekmi laßß3an tampona limbon Bannobulaan, ma'kadoja lussu', tiaßka'mi laßnan sapanna minaßa Datu baine ma'manuk dirampanan.

742 Umpotampami tampa rapa'na, umpokombor komboß sirurunna.

$736 U m b a$ nakita batu ba'tanmu= Where does the glance of the kernel of thy innermost being direct itself?

Tiapa natontoni karanan inaammu $=\mathrm{U}$ pon what does the kernel of thy inwardness always look?

738 ma'rebonan didi $=$ to count by breaking off pieces of the leaf ribs of the sugar palm. This method of counting out is used when tallying up the number of transgressions committed by a sick person. The consequent atonement offering is determined by divination, by the splitting of reed stalks.

tuyu rante is a kind of rush that grows on damp, flat ground. Splitting these rushes is also used as a method of tallying up the number of transgressions.

a'riri bonga ura'na "the poles with strong fibres"; these words are the parallel of "house".

739 "the tearing off of the leaves of the dragon's blood plant", refers to the opening rite of the maro feast when the leaves of the dragon's blood plant, which are used at this feast, are torn off the bush. 
733 "Here we are with the medicine, in order to spit it out, but our innermost being is bewildered,

the kernel of our inwardness is confused."

734 "It is as though we are going into an impenetrable forest, it is as if the path we are taking is in thick undergrowth."

735 "It is no open path on which we are going, it is no way free of undergrowth, upon which we walk."

736 Then said Puan Matua:

"With what are thy thoughts occupied, Indo' Belo Tumban?"

"On what does the kernel of thy inwardness always meditate, Indo' Buza Sampa?"

737 They replied:

"Let a long journey be made, in order to call Kambunolani',

let a distant tour be undertaken, lasting some seasons, with the object of summoning Ta'dum Kaissanan."

738 "Let him climb here, to the front room of the iron house and fulfil the rites of the atonement offering, breaking in pieces the leaf ribs of the sugar palm,

let him go upwards here, to the front space of the poles with strong fibres, and perform the ritual of the cleansing offering, splitting the rushes of the field."

739 Then began the tearing off of the leaves of the dragon's blood plant, in the iron house,

thereon started the pulling off of the foliage of the croton plant, before the poles with strong fibres.

740 Indo' Belo Tumbay applied thereto the treatment of spitting,

Indo' Buna Sampa' employed thereon the remedy that brings recovery.

741 Then Banno Bulaan mounted to the edge of the water pool, like a crow alighting unhampered,

thereon Datu Baine ascended to the dyke of the sheet of water, like a fowl that has been released.

742 She was then healthy, she had become hale.

741 The expressions "mounted to the edge of the water pool", and "ascended to the dyke of the sheet of water", mean figuratively that the dangerous period of the sickness has passed. While a person is sick he is in a fast flowing river; during the crisis period he is in the middle of the rapids, or in the middle of the river.

minan $a=$ mouth of a river.

Verh. dl. 45 
743 Bendanmi bate manurun, tunannaßmi bandera dianinni.

744 Napondok Puaß Matua lan taßßana laßi', napamaßka salaga To Kaubanan lan una'na to paozanan.

745 Taß mempue sekke'mi pedampi ma'burra, taß messompo berada'mi tamba' ma'pakuli-kuli.

746 Salondo sa'danmo pedampi ma'burra, sa'dan bone-bonemo tamba' ma'pakuli-kuli.

747 Torro pareami lan taßzana laßi', unnesur pasaladanmi lan una'na to paozanan.

748 Urria mellolo tau, ussaladan to sanda raßka'na.

749 Urria ma'bala tedon, ussarande kaeran ma'paßkuß karambau.

750 Urria pare tallu bulinna, ussaladan ke'te' tallu etenna.

751 Urria ianan sanda rupanna lan taßßana lani', ussaladan baraß apa mintu' sola nasaß.

752 Umpatuka'omi pa'batanan Puan Matua, umpasolo'omi pa'inaan To Kaubanan sola Arraß dibatu.

753 Umballa'mi tando' kalua' dao banua bassi, ungaragaimi inan masea-sea dao a'riri bonga ura'na.

754 Umpakendekmi to disalampe manikki.

755 Dilando lalannimi burake manakka, dilaka pa'taunannimi binsu mapato.

743 bate manurun: a long bamboo stake to which a long red cloth is attached. It is erected at the final rite on the last day of the great maro feast. The rite is conducted on a field outside the village. A lesser kind of maro feast is concluded with the mendio' = the bathing in the river, when a smaller cloth is tied to a bamboo stake called bate uai.

744 napamanka salaga $=$ he completed it with a harrow; as a field is worked with the harrow and is then ready for the planting, so is something definitely agreed and ready to be executed.

745 sekke': a bird with a large head and light blue feathers. berada': a small bird with white and greyish feathers.

753 tando' $k a l u a^{\prime}=$ broad platform; this is the platform that is erected before the house where the great $l a^{\prime} p a^{\prime}$ feast is to be held. 
743 Then the great standard stood upright, the banner stood flapping in the wind.

744 Puan Matua stood fast in the centre of the firmament, To Kaubanan was fixed firmly in the highest part of the all-covering roof.

745 So that the treatment of spitting would not be of short duration, like a sekke' bird,

that the remedy that brings recovery should not sit on the shoulder, like a berada' bird.

746 So that the treatment of spitting would be like a river flowing in spate, that the remedy that brings recovery would be like a stream swollen by heavy rain.

747 There it remained, cherishing, in the centre of the firmament, it stayed there, protecting, in the highest part of the all-covering roof.

748 Cherishing the birth of mankind, protecting the ones whose limbs are complete.

749 It cherishes the stalling of the buffaloes, it protects carefully the stabling of the kerbau.

750 Cherishing the three-eared rice, protecting the cut one, branched in three.

751 Cherishing the precious things of all kinds, in the centre of the firmament, protecting all the possessions together.

752 Puan Matua caused thoughts to arise, To Kaubanan made the reflections sink down.

753 Then he extended the large platform to the iron house, thereon he made the broad place before the poles with strong fibres.

$754 \mathrm{He}$ permitted the ones who had been dressed with a beaded scarf to be borne above.

755 Then a long journey was made, in order to fetch the skilled burake, a distant tour was undertaken, lasting some seasons, with the object of bringing back the priestess with supernatural power.

754 A salampe is a scraf, an old woven cloth, which is worn aslant over the body. At the great $l a^{\prime} p a^{\prime}$ feast, the women who perform a function at this feast wear the salampe on their heads.

755 binsu = priestess; it is the older form of bissu. In various territories of Upper Binuan (Mamasa) and Pitu Ulunna Salu she officiates at the melani' feast which is held in those regions. The bissu at the court of Bone was the guardian of the state regalia. 
756 Dilando lalannimi to pedudun tanduk, ditunka mambelami to perande salanka'.

757 Dipalaßßanmi to diboboß bulaanni, simbolon manik, lokkon loerara'.

758 Narundunan bulomi burake manakka dao lisu aninan alukna baine to tumbaß, napasitete malaa'mi binsu mapato dao tanßana sondoß saßka' belon-belonanna to unnisuß to malazi'.

759 Ullambemi ianan sanda rupanna to menani, untambaimi baraß apa mintu' sola nasaß to pedudun tanduk.

760 Dilando lalannimi mintu' la napopake tananan bua', dilaka pa'taunannimi mintu' ronka-ronkana randukan balinono.

761 Dirantemi rante dibunna', dilappa'imi padaß ditallu rarai.

762 Bendanmi goraß bulaanna, tunannanmi pataßdo bulaan.

763 Sumomba'mi to tumbaß tama rante dibunna' situaß pake, situru' to kaijaßanmi to dibobon bulaanmi tama padan ditallu rarai sitonda parea.

764 Bendanmi lumbaa lazi', tunannaßmi paraßka dialuk.

757 "the ones whose partings are adorned with gold", are the to tumban = young girls and women who are in a state of tabu at the great $l a^{\prime} p a^{\prime}$ feast.

758 lisu aninan = centre part over which the wind blows: it is the platform before the house.

sondon: in many regions of the Rantepao country, it means a small room on the north side of the house and which is slightly higher than the platform.

to malani $i^{\prime}=$ those who sing and dance; it is another description of the to tumban. The word malani' is a derivation of lami' $=$ the firmament; it also means belonging to the sphere of the upper world; $\mathrm{cp}$. melani the name for the bissu feast in the Upper Binuan country, see 755.

759 The enumerating of the names of valuable things of all kinds contains the wish to acquire them.

762 goran: a platform on high poles erected on the feast place of the $l a^{\prime} p a^{\prime}$ feast and to which the to minaa mount in order to speak their blessings from a height.

patando: the trunk of a casuarina tree which is fastened across the breadth of the house to the rafters near the anak dara. These anak dara consist of four pieces of bamboo bound together in a bundle with the leaves of the sugar palm and other plants, and attached, with a shield and a sword, to the north side of the centremost main pole of the house. 
756 A long journey was made, in order to fetch the men who wear horns on their heads,

a distant tour was undertaken, lasting some seasons, with the object of bringing back the ones who hold on the palms of their hands the baskets in which fish are caught.

757 Then the ones whose hair partings are adorned with gold, were taken on high,

the ones who have knots of hair, shining like beads, who have rolls of hair, hanging down, like golden neck ornaments.

758 The skilled burake regulated in good order, from the beginning to the end, the rites of the women, the to tumbay, on the centre part over which the wind blows,

the priestess with supernatural power, ordered in a proper manner, in the middle of the front space, the required adat performances of the ones who were placed there as dancers.

759 The to menani called the names of the precious things of all kinds, the ones who wear horns on their heads, summoned all the possessions together.

760 A long journey was made, in order to fetch that which was to be used as an adornment at the performing of the bua' feast,

a distant tour was undertaken, lasting some seasons, with the object of bringing back all the ornaments for the holding of the procession at the $l a^{\prime} p a^{\prime}$ feast.

761 The place of the feast, where the digging stick was to be stuck, was made flat,

the field that was to be covered with three kinds of blood, was levelled.

762 The high golden platform stood upright, the splendid casuarina trunk stood on end.

763 The to tumban went in procession to the place of the feast, where the digging stick was to be stuck, robed in festival clothing,

the ones whose hair partings are adorned with gold, went like a cortege to the field that was to be covered with three kinds of blood, making dancing movements, in festival attire.

764 Then the thick bamboo stood upright, the ritual stone, set in the ground before the house of the feast, stood on end.

764 paranka: the stone which, together with a tjendana tree and magically powerful plants (dragon's blood and sirri-sirri (Cordylina fructuosa)) is set in front of the house where the $l a^{\prime} p a^{\prime}$ feast is held. 
765 Randukomi Kambunolani' bendan ma'tali maa', petoe soßkaß, sikaßkan doke diremak.

766 Umpasirundunan bulo nene' mendeatanna titanan tallu, nene'na manuk, nene'na bai, nene'na tedoß.

767 Tipamulannaomi Ta'duß Kaissanan tunannaß ma'tompu masura', pedeken panaaran, sikaßkan induk disila bannaß.

768 Umpasitete malaa' to dolo kapuaßanna, samba' batu lalikan.

769 Sundunmi rekke lolokna alukna kalaparan lan taßßana laßi', upu'mi laßßan pendaunanna saßka' beloß-belozanna tananan bua' lan masuaßgana to paoranan.

770 Torro pariami lan taßzana lani', pasarande kaeranmi lan una'na to paozanan.

771 Urriami mellolo tallu, ussaladanmi sibidaß tauninna.

772 Tia'danomi ade' burana Tanduß Siulu, taß ponno suka'namo lupa'na pananda uai.

773 Umbaliaßanomi batu ba'tanna Puaß Matua, umbibi'omi karaßan inaanna To Kaubanan.

774 Bendanmi ade' raukan tedon lan tampona Tanduß Siulu, tunannaßmi ade' tokonan karambau lan tompokna Minaßa To Palulluzan.

774 tokon $=$ to strike directly beneath with a lance. 
765 Then began the custom of Kambunolani' rising to his feet wearing as a head cloth an old short wide woven cloth, a bamboo container in his hand,

holding a lance on which an areca nut had been stuck.

766 In regular order, he mentioned the divine progenitors of the ones that are established as a trinity,

the begetter of the fowl, the begetter of the pig, and the begetter of the buffalo.

767 Then Ta'dun Kaissanan stood there for the first time, wearing a band, decorated with a design, on his head,

grasping a small bamboo container, holding in his hand the wood of the sugar palm, cleft along the prescribed line.

768 One by one, he mentioned, in the correct manner, the lords, revered as the progenitors of the trinity belonging together, like the three stones of the hearth.

769 The rites of the $l a^{\prime} p a$ feast were completed, right to the top, in the centre of the firmament,

the adat performances required at the holding of the bua' feast, were brought to an end, to the topmost one, in the highest part of the all-covering roof.

770 There it remained, cherishing, in the centre of the firmament, protecting carefully, in the zenith of the all-enfolding.

771 Cherishing the birth of the trinity, protecting the ones whose placenta belong together, like strips of woven cloth.

772 Then it was, so we are told, that the produce of The field lying at the head [of the firmament] did not reach its full quantity, it was then that the harvest of the sawah, dyked to keep the streaming water in bounds, was below its measure.

773 Puan Matua again brought his innermost being into movement, To Kaubanan again brought the kernel of his inwardness into action.

774 Then, so we are told, the stabbing of the buffalo took place on the dyke of The field lying at the head [of the firmament], thereon, so it is said, the spearing of the kerbau happened on the dam of The water pool of the all-enfolding. 
775 Dilando lalannimi mintu' la napopake surasan tallaß, ditußka mambelami mintu' roßka-roßkana ra'buß diaßgilo, nasielleran karidisan pandun balo.

776 Randukomi Kambunolani' bendan petoe sonkaß, ma'tali maa', sikaßkan doke makabombonan, tipamulannaomi Ta'dun Kaissanan sikaßkan pasoan bani'.

777 Unnalami ade' Puan Matua sendana lanmai tampona limboß, nakala'pami ade' To Kaubanan lanmai tompokna minaßa tua kaju ma'rara tau.

778 Nakua: Indemo sendana sugi' la tanii ussankin tedon ma'bulu aluk, apa iamo kaju ma'rara tau, indemo kaju mentaßke ianan la tanii ulla'ka' karambau massongo bisara, iamo kaju ma'lomba' to lino.

779 Dipamulannami sendana sugi' dinii ussankin tedon ma'bulu aluk, bußza'na kaju mentaßke ianan dinii ulla'ka' karambau massongo bisara.

780 Sundunmi rekke lolokna raukan tedon lan tampona Tanduß siulu, upu'mi laßßan pendaunanna tokonan karambau lan tompokna minaßa tua.

781 Torro paria, unnisun pasaladan, sakendek-kendeknami burana Tanduß Siulu, salazßan-laßzannami lupa'na Minaza To Palullußan.

775 The kapok on the leaf ribs of the sugar palm is smeared with blood and these ribs are then attached to the outer ends of the bamboo struts of the small offering table.

776 As in the rite of the ma'tambuli, where the to minaa performs the symbolic act of digging a hole in which to plant the tjendana tree to which the buffalo that is to be slaughtered, is tied, so in the rite referred to in this strophe, he holds in his hand a lance with a small scoop at the end.

777 "a tree with the blood of a human being", is a poetical description of a tjendana tree with red wood. 
775 Then a long journey was made, in order to fetch everything to be used at the offering on the small offering structure of bamboo struts on which a design is cut,

a distant tour was undertaken, lasting some seasons, with the object of bringing back all the things with which the bamboo with incised lines is adorned,

to which must be attached the leaf ribs of the sugar palm wrapped round with small pieces of blood-smeared kapok.

776 Then began the custom of Kambunolani' rising to his feet, wearing as a head cloth an old short wide woven cloth, a bamboo container in his hand, holding a lance with a small scoop fixed on the end, there stood for the first time Ta'dun Kaissanan, in his hand the shaft of a lance, on which was a spoon-shaped object.

777 Puan Matua, so we are told, fetched a tjendana tree from the dyke of the water pool,

To Kaubanan, so it is said, brought the tree with the blood of mankind, from the dam of the old sheet of water.

778 He said:

"Here is the richly laden tjendana tree to which we shall bind the buffalo with skin befitting the offering rites, for this is the tree with the blood of mankind,

herewith is the tree whose branches are full of precious things, to which we shall tie up the kerbau with neck hair suitable for the adat performances, the tree with the life-fluid of the people of the earth."

779 Then began the custom of binding the buffalo with skin befitting the offering rites, to the richly laden tjendana tree,

for the first time, the kerbau with neck hair suitable for the adat performences, was tied to the tree whose branches are full of precious things.

780 The conducting of the feast of the stabbing of the buffalo was completed, right to the top, on the dyke of The field lying at the head [of the firmament],

the feast of the spearing of the kerbau was brought to a complete end, to the highest point, on the dam of the old sheet of water.

781 There it remained as a cherishing force, there it stayed as a protection, then the produce of The field lying at the head [of the firmament] grew in abundance,

the harvest of the old sheet of water of the all-enfolding, increased more and more. 
782 Sirampananmi kapa' Kundailaņi' Kambunolanji',

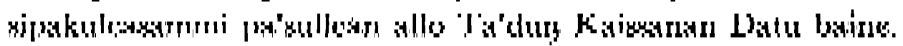

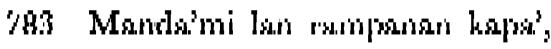
bintinmi lan pa'sullean allo.

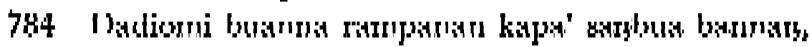

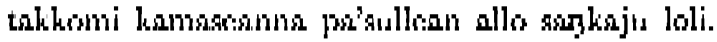

785 Kasallemi dadinna, lobo' garaganna,

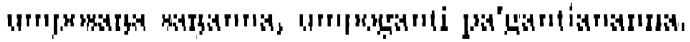

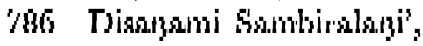
diganti Datu muane.

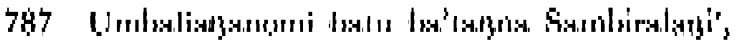
umbili' harsygn inamma Datu muane.

788 Randukmi rumlmpan kipsi' lako binloen tasak,

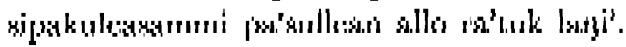

789 Mandri'omi lan rampanan kapa' Sambiralagi',

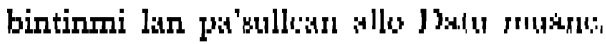

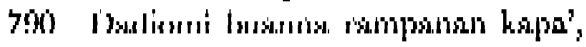
talckoni kamnseanna pa'sullean allo.

791 Kasallemi ditdinnts,

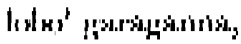
umposoyami sagnana, umpogantimi pa'gantinnanna.

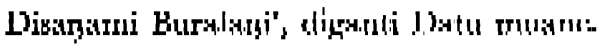

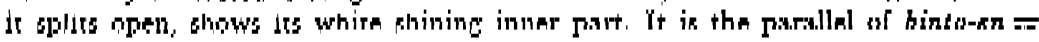
sเir. 
782 Kundailani' concluded a marriage with Kambunolani, Ta'dun Kaissanan entered into a union with Datu Baine.

783 They were steadfast in the marriage, they were constant in the union.

784 Then a single fruit was born of the marriage, thereon came into the world a sole gift of the union, well-shaped.

$785 \mathrm{He}$ reached maturity, his form developed fully, and he received his name, and was given his other name.

786 He was called Sambiralani, and his other name was Datu Muane.

787 Sambiralani' brought his innermost being into movement, Datu Muane brought the kernel of his inwardness into action.

788 And he concluded a marriage with a yellow-shining star, he entered into a union with a roasted split open rice grain of the firmament.

789 Sambiralani' was steadfast in the marriage, Datu Muane was constant in the union.

790 Then again a fruit was born of the marriage, there came into the world a gift of the union, well-shaped.

$791 \mathrm{He}$ reached maturity, his form developed fully, and he received his name, and was given his other name, he was called Buralani, and his other was Datu Muane.

791 Buralani $i^{\prime}=$ Foam of the Firmament, Fruit of the Firmament. 


\section{G. MA'PALLIN}

1 Nalambi'mo te allo maelo, sikabu'tuammo te kulla' mapia dadi.

2 Aßki siindo'mo te tananan pallin inde rampe matampu', aßki sisaladanmo randukan passalearan.

3 Apa to nasazindoran tananan pallin, apa to nasazamberan randukan passaleaßan?

4 Den manii rapu indukki sala dion ballaran ampa', den manii kikatumanai dion rantean tuju.

5 Mintu'na tu salaki, makalima'na to kikatumaßai, iamoto anki siindo' tananan pallin, anki sisaladan randukan passaleanan.

1 In the Mamasa district (Upper Binuan), the word mapia is the colloquial term for good, beautiful; in the $S a^{\prime} d a n$ territory, it is a poetical word.

2 sisaladan: to hold each other on the lap.

randukan: the action of sticking it in the ground.

3 samamberan: to have the same father. 
C. THE PRAYER AT THE RITE FOR THE WARDING OFF OF EVIL FORCES

1 This good day has come, this radiant one, beautiful of being, is shining on us.

2 So that we together may undertake the performing of the pallin offering, at the western side,

in order that we, each one with the other, may concern ourselves with the holding of the expiatory offering.

3 What is the significance of our undertaking together the performing of the pallin offering,

what is the meaning of our concerning ourselves, each one with the other, with the holding of the expiatory offering?

4 It may be that one of the members of our lineage, numerous as the leaves of the sugar palm, has committed an offence, after the unrolling of the mat,

perhaps we have transgressed, after the spreading out flat of the rushes.

5 For all the offences, for everything in which we have transgressed, do we undertake together the performing of the pallin offering, do we concern ourselves, each one with the other, with the holding of the expiatory sacrifice.

4 "has committed an offence, after the unrolling of the mat", and "have transgressed, after the spreading out flat of the rushes", both refer to sexual offences, especially extra marital sexual relations with a closely related member of the family. 


\section{LIKARAN BIAn}

1 Nalambi'mo te allo maelo, nadete'mo te kulla' mapia dadi.

2 Aßki tundan to mamma'komi, Puaß Matua, dao taßßana lani', anki rujaß to matindokomi, To Kaubanan, dao una'na to palulluzan.

3 Anna Puan Bassi-bassian, anna Puan Ambo-amboan,

4 deata taßßana laßi', puan barrena allo,

5 kamu deata mamase, kamu puaß sa'pala buda,

6 lumban petiro aluk, lukku pemanta bisara.

7 Mintu' deata ilani', makalima'na puaß to palulluzan.

8 Puan Matua ia sikorok london sandeatanna, To Kaubanan ia sititian baan mintu' deata ilani',

9 makalima'na puaß to palullußan.

10 Tae' salianna rindin, tae' leko'na manaßza banua. ${ }^{\text {) }}$

15 Pokinallokomi mellolo tau, pobokoß dilambanaßkomi to sanda raßka'na.

16 Pokinallokomi to ma'puduk mundan, pobokon dilambanaßkomi to ma'illoß karumisik.

17 Pokinallokomi pare tallu bulinna, pobokoß dilambanaßkomi ke'te' tallu eteßna.

a) Strophes 11 to 14 are similar to strophes 99 to 102 of B, and are therefore not included.

2 When the person reciting the invocation calls upon the gods to descend in order to accept the offering meal, he is calling upon deities who are considered to be sleeping. He therefore uses the words "awaken" and "arouse" - strophes B $89,141,202$; D 2, 28, 41; G 48a, 80, 130. When the gods are requested to invite their co-gods, the words "summon" and "call" are used - strophes B 97, 208 ; D 8, 33. When the reciter says that he has invited the gods from the four quarters, when he says in the ' $a$ ' line "fingering the strumming instrument", and in the ' $b$ ' line "plucking the golden strings", he uses the words "summon" and "call" - strophes B 94, 177; G 52, 108.

10 salianna rindin: that remaining outside the wall.

leko'na manamza banua: that which is on the wrong side (the outside) of the 
D. THE PRAYER AT THE RITE AT WHICH THE OFFERING MEAL, PLACED IN A SMALL BASKET MADE OF INTERWOVEN LEAVES OF A REED, IS LAID DOWN

1 This good day has come, this radiant one, beautiful of being, has dawned.

2 So that now we awaken thee, Puan Matua, there above, in the centre of the firmament, as one who sleeps, we arouse thee, To Kaubanan, above, in the zenith of the all-enfolding as one who slumbers.

3 And also Puan Bassi-bassian, and Puan Ambo-amboan.

4 The gods of the centre of the firmament, the lords of the shining sun.

5 Thou merciful gods, thou lords great of compassion.

6 Who bendest forward, in order to look down upon the offering rites, who stoopest down, with the object of observing the adat performances.

7 All the gods in the firmament, the lords of the all-enfolding, complete in number.

8 Puan Matua calls his co-gods together, as a cock gathers the hens by crowing,

To Kaubanan summons all the lords in the firmament to assemble together, as a parakeet shrieks the call to foregather.

9 The lords of the all-enfolding, complete in number.

10 There are none there who stand aside, not one of them there is excluded.

15 As sustenance for the journey, take the birth of human beings, as provisions on the way, take the ones whose limbs are complete.

16 As sustenance for the journey, take the ones with lips like those of the wild duck, as provisions on the way, take the one whose nose is like that of a small wild duck.

17 As sustenance for the journey, take the three-eared rice, as provisions on the way, take the cut one, branched in three.

broad posts where the wooden panels of the house are placed.

15 mellolo tau: the coming forth of the umbilical cord of a human being.

lambanan: the place where people cross. 
18 Pokinallokomi paßkunna bai, pobokon dilambanaßkomi bujanna manuk.

19 Mipokinallo ilalan tindo maelo, mipobokon dilambanan mamma' makatoßzan-tonan.

20 Mipokinallo ilalan mendaun sugi', umpobokon dilambanan menta'bi ianan.

21 Mintu' to la dipoinaa, makalima'na to la dipoba'taß.

22 Ammi burka' baba'na lazi', ammi killaß pentiroan to palulluzan.

23 Ammi bozsoran eran manikmi, ammi randukan kalisuan bulaanmi.

24 Ammi ma'lalan tindak sarira, ammi ma'lambanan taraue.

25 Ammi rampo lembaß inde padan tuo balo', ammi tu'tun koli-koli inde tana tumbo kulau'.

26 Ammi ma'pazan-panan massola nasaß, ammi ma'damerak-merak saßga mairi'.

27 Mimetaa mammi', mimelale' sanda marasa.

28 Anku tundano sandeatammi inde dion maririnna litak, aßku rujaßo saßkapuaßammi dion maßapi'na tana.

29 Deata dibanunni banua rokko, diosokki a'riri sanda pati'na.

30 Deata patulak annan, palaßjda' karua, parande pala', pasarande taruno.

31 Deata mamase, puan sa'pala buda.

32 Mintu' deata to kerkok, makalima'na puaß to kebali'bi'.

33 Puan untulak padaß sitamban saßdeatanna, puaß to kebali'bi' sikorok london saßkapuaßanna.

34 Ammi garaga saßke'deran, ammi tampa saßtiaßkaran.

30 "the six supporting gods", and "the eight who prop up", are the gods who live under the earth and upon whom the earth rests. 
18 As sustenance for the journey, take the pigs' sty, as provisions on the way, take the perches on which the fowls sit.

19 As sustenance for the journey, take an auspicious dream, as provisions on the way, take a pregnant nocturnal vision.

20 As sustenance for the journey, take a quantity of possessions, numerous as the leaves of the tree, as provisions on the way, take precious things, abundant as flowers.

21 Everything that people have in their thoughts, all the things of which people are mindful.

22 And shall the door of heaven be opened, and shall the window of the all-enfolding be thrown open.

23 Shall thy stairs of beadwork be lowered, shall thy golden steps be let down.

24 Let the rainbow then be thy path, thou shalt make thy way along the arch of the sky.

25 So that thou arrivest at this blessed region, like the coming of a prau, in order that thou comest to this blissful land, like a small boat bumping [against the landing stage].

26 All shall then chew betel, together, then, shall all of thee make thy mouths red.

27 And thou shalt laugh in a friendly way, and smile thy sweetest smiles.

28 Let me also awaken thy co-gods here below, in the clefts of the earth, let me arouse the ones who, with thee, are revered as lords, here in the depths of the layers lying on each other.

29 Gods upon whom the houses are built, upon whom the poles, that are cut to their correct size, are erected.

30 The six supporting gods, the eight gods who prop up, the ones who hold [the earth] on the flat of their hands, who bear [the earth] on their fingers.

31 Merciful gods, lords great of compassion.

32 All thou gods of the underworld, all thou lords of the subterranean region.

33 Let the gods who support the earth, call together their co-gods, let the lords of the subterranean region summon all the ones who, with them, are revered as lords, as a cock gathers the hens, by crowing.

34 Arrange a complete start, form a united departure. 
35 Sipadolo-dolomi, sipataßßа-taßßаmi, sipaundi-undimi.

36 Apa da ammi ma'kambelaß-belaß, da ammi ma'bantala-tala.

37 Pokinallokomi ianan sanda rupanna, pobokoß dilambanaßkomi baraß apa mintu' sola nasaß.

38 Ammi pabendan eran manikmi, ammi pate'daß kalisuan bulaanmi.

39 Ammi bille lolokna riu, ammi poli' taßke luana.

40 Ammi sitammu saßdeatammi ma'paßan-paßan, ammi sirompa' saßkapuanammi ma'damerak-merak.

41 Aßku tundanopa saßdeatammi lan kapadaßanna, kurujazopa sankapuanammi lan kapajan-pajananna.

42 Deata kambi'na te padaz tuo balo', puaß taranakna te tana tumbo kulau'.

43 Deata kisano'koran, puan kisanisuran.

44 Deata kitimba bubunna, kisiok mezgulilinna.

45 Deata kileller kajunna, kile'tok tanan-tanananna, kikalette' utan malunanna.

46 Deatanna pole padan diKesu', puanna padaß diBeloara'.

47 Deata napobura' tonkon nene' mendeatanki, puaß tipamulanna napaunnisuß to dolo kapuanaßki.

48 Deata malute pakorok london lako sandeatanna, puaß mabaßko patiti ambaan lako sankapuaßanna.

49 Garagamokomi sanke'deran, tampamokomi santiankaran.

50 Ammi pokinallo baraß apa sanda rupanna, ammi pobokon dilambanan ianan sanda makamban.

47 napaunnisum $=$ they sat themselves down. 
35 Let the ones who stand in front go together and lead the way, the ones in the middle go together in the centre group, and the ones who are last go together at the end.

36 But thou shalt not go empty-handed, thou shalt not be without anything.

37 As sustenance for the journey, take now all kinds of possessions, as provisions on the way, take everything that is precious.

38 Shall thy stairs of beadwork then be erected, shall thy golden steps be raised.

39 Separate the heads of the grass, push aside the stalks of the luana grass.

40 Come to meet thy co-gods at the chewing of the betel, come with the ones who, with thee, are revered as lords, and together make thy mouths red.

41 Let me now also awaken thy co-gods on the earth, let me now also arouse the ones who, with thee, are revered as lords of the open fields.

42 Thou gods who guard this blesséd region, thou lords who watch over this blissful land.

43 Gods among whom we sit together, lords with whom we take our places.

44 Gods from whose wells we scoop, lords from whose bubbling [wells] we draw.

45 Gods whose timber we cut down, whose plantations we harvest, lords whose lush verdure we pluck.

46 God of the Kesu' territory, lord of the district of Beloara'.

47 God whom our divine ancestors requested to be the first to sit down with us,

lord whom our forefathers, revered as lords, begged to be the first to take a seat here.

48 Gods who, in a fluent way, call thy co-gods together, as a cock gathers the hens, by crowing,

lords who summon in a skilled manner the ones who, with thee, are revered as lords, as a parakeet shrieks its call.

49 Arrange a complete start, form a united departure.

50 As sustenance for the journey, take all kinds of possessions, as provisions on the way, take the greatest possible quantity of precious things. 
51 Ammi rampo lembaß inde te padan tuo balo'.

52 Sitammu saßdeatammi ma'paßan-panan, ammi sirompa' saßkapuaßammi ma'damerak-merak.

\section{E. MAMRAMBU LAクI'}

1 Puaß Matua dao taßßana laßi', Puaß To Kaubanan dao masuangana to palullußan.

2 Puan Bassi-bassian, Puan Ambo-amboan, Puan Poß Tulakpadan inde dion, puan parande paduduß.

3 Deata iKesu', puaß Beloara'.

4 Mintu' deata nasambo lazi', narande tana kalua'.

5 Siindo'mokan rambuan lani', sisaladanmokan oroan to palulluran.

6 Tumbai ammu sïndo' rambuan lani', tiapai ammu sisaladan oroan to palulluzan?

7 Iamo kisiindo' rambuan lazi', denkan manii ma'rapu tallaß malin dioß ballaran ampa', denkan manii to ma'limbo kaluku leaga dion rantean tuju.

8 Iamo kisiindo' rambuan lari', iamo kisisaladan oroan to palulluzan.

9 Sanda to kundun la kiperumpani dio ma'rapu tallaß, upu' to pakalubamban la kipetalatai dio to ma'limbo kaluku.

9 to kundun: that which sticks out above a flat object, e.g. a mat, and causes trouble.

to pakalubamban: that which sticks out lengthwise over a flat object and impedes. 
51 So that thou arrivest here at this blesséd region like the coming of a prau.

52 In order to meet thy co-gods at the chewing of the betel, with the object of uniting with the ones who, with thee, are revered as lords, while making thy mouths red.

\section{E. THE PRAYER AT THE OFFERING TO COVER UP GUILT}

1 Puan Matua in the centre of the firmament, To Kaubanan in the zenith of the all-enfolding.

2 Puan Bassi-bassian, Puan Ambo-amboan, Lord Pon Tulakpadan here below, lord who holds on his hand and bears on his head.

3 God of the Kesu', Lord of Beloara'.

4 All the gods over whom the heaven arches, whom the wide earth bears on her hands.

5 We, together, suffer the firmament to be veiled with smoke, we, each one with the other, permit the bringing of impure air to the all-enfolding.

6 Why doest thou, together, suffer the firmament to be veiled with smoke, for what reason doest thou, each one with the other, permit the bringing of impure air to the all-enfolding?

7 Here is the reason that we, together, suffer the firmament to be veiled with smoke,

it may be that we, who are a lineage, multitudinous as bamboo culms, have committed an offence, after the unrolling of the mat,

it could be that we, who are as numerous as coconut palms standing together, have transgressed, after the spreading out of the rushes.

8 That is the reason that we, together, suffer the firmament to be veiled with smoke,

that is why we, each one with the other, permit the bringing of impure air to the all-enfolding.

9 Everything that disturbs the good order of the arrangements, we desire to remove from the lineage, multitudinous as bamboo culms growing together on a stool,

all the things that conflict with the adat prescriptions, we wish to cut out from the family, numerous as coconut palms standing together. 


\section{F. MADRIMPUn}

1 Kamu to diponene', kamu to dipotomatua.

2 Nene' bußa' mellao lani', to dolo tipamulazki turun dibintoen.

3 Nene' silau' eran, to dolo sitanke pelalan.

4 Nene' maßanna saßka', to dolo pa'palumpunan dibisara.

5 Nene' dolo, nene' taßßa, nene' undi, pakapaka to pada tindo.

6 Mintu' to kiporara rarana, makalima'na to kipolomba' lomba'na.

7 La ma'panan-paßanmokomi, la ma'damerak-merak.

8 Mibura'kan lindo masakke, mipi'pikkikan rupa madadindin.

5 "thou who hadst the same kind of dream", are the ancestors who, in olden times, in the war against Bone, against Arum Palakka, had agreed at the lighting of fires on the top of the mountains to assemble at the Sarira rocks and from there to march against the advancing people of Bone; these ancestors are also called to ma'pasa' bon $i=$ the ones who held a market at night. 
F. THE PRAYER AT THE COMMUNAL OFFERING TO THE ANCESTORS

1 Thou who art our ancestors, thou who art our forefathers.

2 The ancestors, the first descending from heaven, our forefathers from the time beyond memory, who came down from the stars.

3 Ancestors, following each other, like the steps of a stair, forefathers, succeeding each one after the other, like the rungs of a ladder.

4 Ancestors who guarded the arrangements, forefathers who provided us with the adat prescriptions.

5 Ancestors from the time beyond memory, the middle period, and the later time, above all, thou who hadst the same kind of dream.

6 All of thee who art our blood kinsmen, everyone of thee whose blood is ours.

7 Come now and chew betel, now make thy mouths red.

8 Sprinkle us with an auspicious face, let a benevolent countenance drip down upon us.

6 mintu' to kiporara rarana and to kipolomba' lomba'na mean: whose blood we have as blood. 


\section{G. MA'BUBUn}

Kada napokada to minaa, ke umpatorromi paßan.

1 Nalambi'mo te allo maelo, nadete'mo te kulla' mapia dadi.

2 Anki patundan to mamma' mati' taßnana lani', anki parujan to matindomo mati' inanna to palullußan.

3 Apa kamu, Puar Matua, kitundan to mamma', kieranni kapuran pazan.

4 Kamu, To Kaubanan, kirujaß to matindo, kipelalanni te lambaran baolu.

5 Kamu, Puan Bassi-bassian, kamu, Puan Ambo-amboan.

6 Kamu lumbaß petiro aluk, lukku pemanta bisara.

7 Kamu deata mamase, puaß sa'pala buda.

Kada napokada to minaa, ke ma'pesuni.

8 E puan! e puan! e puan!

Puaß Matua dao taßß ana lani', To Kaubanan dao masuangana to palullußan!

9 Puaß Bassi-bassian, Puaß Ambo-amboan.

10 Deata taßnana lani', puaßy barrena allo.

11 Deata kitiro tuka', puaßz kimanta lu laßßan.

12 Deata napabura' toßkon nene' mendeataßku, puan tipamulanna napaunnisuß to dolo kapuananku.

13 Deata umpasisuka' boni na allo, puan umpasikararoan tanda malillin na masian. 


\section{G. THE PRAYER WHEN THE RIDGE GOVERING OF FLATTENED-OUT BAMBOO CULMS IS LAID ON THE ROOF}

The words spoken by the to minaa as he lays down the sirih-pinang.

1 This good day has come, this radiant one, beautiful of being, has dawned.

2 It is for this reason that we awaken thee as sleeping ones, there in the centre of the firmament, that we arouse thee as slumbering ones, there at the place of the all-enfolding.

3 Thou, Puan Matua, we awaken as a sleeping one, and begin the dusting of the betel quid with lime, as a step to thee.

4 Thou, To Kaubanan, we arouse as a slumbering one, and start the laying down of betel leaves, as a ladder to thee.

5 Thou, Puan Bassi-bassian, thou, Puan Ambo-amboan.

6 Thou, who bendest and lookest down on the offering rites, thou, who stoopest to observe the adat performances.

7 Thou, merciful gods thou, lords great of compassion.

The words spoken by the to minaa when he offers the offering meal.

8 O Lords! O Lords! O Lords!

O Puan Matua in the centre of the firmament!

O To Kaubanan in the zenith of the all-enfolding!

9 O Puan Bassi-bassian! O Puan Ambo-amboan!!

10 Gods of the centre of the firmament, lords of the shining sun.

11 Gods whom we see ascending, lords whom we behold rising upwards.

12 God whom my divine ancestors requested to be the first to sit down with us,

lord whom my forefathers, revered as lords, begged to be the first to take a seat here.

13 God who balanced the period of the night and the day against each other,

lord who marked out the mutual relation of the dark and the light time. 
14 Iamo deata umpaturara padaß, iamo puan umballa' rante kalua'.

15 Iamo deata ußgaraga uma ma'kambuno lumu', iamo deata ußkombon panompok doke-dokean.

16 Deata umpakalolo tetean tampo, puaß unna'ta' pananda uai.

17 Deata untanan pesuran banne sirenden, puaz unnosok pa'tagarian.

18 Deata lumumbaß lani', puaß sumonko' to palullußan. ${ }^{a}$ )

30 Deata mamase, puaß sa'pala buda. ${ }^{\mathbf{b}}$ )

36 Taß nalambi' randan pudukna taß sipolili'ki, taß nadete' dara' leß̧o lilana taß sipogontinki.

37 Randan pudukki kami ullambi' nakambio santuß, dara' lenko lilaki kami undete'i nako'bi' riti bulaan.

38 Taß dilambi'na, taß didete'na.

39 Ma'guluß-gulußanna, pidun-pidunanna.

40 Massaloko batunna, massondon kandaurena, ma'tampak pelole'na, ma'lolok didinna laßzan.

41 Ma'eru' balusunna lanßan, ma'tampak telo-telo. ${ }^{\text {c) }}$

48 La kutundanomo saßdeatammi dion kalambunan allo, deata sanda karua dioß, puaß ganna' bilaßanna.

49 Deata sanda karua lo' enkok bulaanna lani', puaß ganna' bilaßanna.

50 Deata sanda karua daa ulunna lani', puaß ganna' bilaßanna.

a) Strophes 19-20 are identical with strophes 54-55 of $\mathrm{B}$, and are therefore not included.

Strophes $21-29$ are indentical with strophes $57-65$ of $B$, and are therefore not included.

b) Strophes $31-35$ are identical with strophes $69-73$ of $\mathbf{B}$, and are therefore not included.

c) Strophes $42-47$ are identical with strophes $82-88$ of $\mathrm{B}$, and are therefore not included. 
$14 \mathrm{He}$ is the god who laid out the ricefields, he is the lord who spread out the broad plain.

$15 \mathrm{He}$ is the god who made the ricefields, with duckweed as a sunshade, he is the lord who formed the dyked sawahs, full of water plants.

16 God who stretched out straight the line of dykes of the ricefields, who extended the dams of the sawahs, that keep the streaming water in bounds.

17 God who delineated the offering places, one after the other, in the ricefields,

lord who marked out the places on the ground where the fragrant grass is burnt.

18 God who arched the firmament downwards,

lord who curved the all-enfolding as the covering roof.

30 Merciful gods, lords great of compassion.

36 The tips of the lips of the ones who do not belong to our region, do not reach unto them,

all the words spoken, in their regular order, by the ones who are not of our fixed territory, do not penetrate unto them.

37 The tips of our lips, fingering the strumming instument, do reach unto them,

all the words spoken by us, in their regular order, plucking the golden strings, do penetrate unto them.

38 They are inaccessible, they are unapproachable.

39 In their sublimity they are not to be beheld, they are in blue haziness.

40 Their zenith goes to a point and is tipped with a stone, it is wide-based and narrow at the top, like a piece of beadwork, its point is like the sharp rolled young leaves of the sugar palm, its tip, rising upwards, is like that of the leaf ribs of the sugar palm.

41 It tapers to a thin end, like an armband of white shell, its summit is at infinity.

48 Let me now awaken all thy co-gods where the sun descends, the lords, all eight of them, there below, complete in number.

49 The gods, all eight of them in the South, at the golden back of the firmament, the lords, complete in number.

50 The gods, all eight of them in the North, at the head of the firmament, the lords, complete in number. 
51 Deata sanda karua lan taßß̧ana laßi', puaß ganna' bilaßanna.

52 Silelekomi kupalilin kanan, kukambio santuß, upu'mokomi kutamben bala tedoß, kuko'bi' riti bulaan.d)

69 Nasakendek-kendekna mendaun sugi' te to ma'rapu tallaß, nasalazßan-laßnanna mentaßke ianan te to ma'kaponan ao'.

70 Nakallo taßßana lani', nase'pa' barrena allo.

71 Natonton ma'lamba' lajuk lan taßßana tondok, nanenne' ma'barana' paozanan.

72 Napentioßanni baka direzße', napellalundunni kolozan disariri tau kamban. ${ }^{\mathbf{e}}$ )

78 Ammi bolloan barra' ianan sanda rupanna rokko rianna te to ma'rapu tallaß, ammi baku amboran baraß apa mintu' sola nasaß rokko salenka rara'na te to ma'kaponan ao'.

79 Apa kamumo deata mamase, kamumo puan sa'pala buda.

80 Anku tundanopa sandeatammi dion maririnna litak, aßku rujaßopa saßkapuaßammi dion maßapi'na tana.

81 Deata dibanunni banua rokko, diosokki sanda pati'na, deata sipatu botto ulunna diolai dion mai.

82 Deata parande pala', pasali-sali pasarande taruno.

83 Deata patulak annan, palaßda' karua.

84 Deata umpasisuka' boni allo dion, puaß umpasikararoan tanda malillin na masiaß.

d) Strophes 53-68 are similar to strophes 99-115 of B, with the exception of strophe 111 of B, which does not occur in G; they are not included here.

e) Strophes $73-77$ are similar to strophes $117-122$ of B, but strophe 120 of B does not occur in G; they are not included here.

70 usse'pa': to cut throught quickly, at once.

71 lamba': a tall broadly spreading tree with large shiny leaves, a kind of fig Figuratively, the meaning of lamba' is a powerful lord, the guide of the adat community.

72 baka direnze': a carrying basket carried on the back and held by a band passing across the forehead. It is a figurative term for the ordinary people; they are also called the to diremze' $=$ those who are carried, i.e., by the parenze' $=$ those who bear the responsibility for the adat community, who guide it. The ordinary man is also termed to kamban = the great mass.

koloman disariri: that which is carried on the back by means of a band passing diagonally across the shoulders. 
51 The gods, all eight of them in the centre of the firmament, the lords, complete in number.

52 Round thee now have I gone from the right, fingering the strumming instrument, summoning thee,

I have now come to the end of calling thee, plucking the golden strings, from low unto high.

69 So that the clan members, numerous as bamboo culms, may always increase in wealth, in quantity like the leaves,

in order that the branching of the precious things of the ones whose group always increases like a bamboo stool, may continue to swell still more.

70 May they almost reach to the centre of the firmament, may they cross the shining disc of the sun.

71 May they continually stand in the middle of the village, like a fig tree, rising on high, may they always be like sheltering waringin trees.

72 May the ordinary people have a place of shelter beneath them, may the ones whose guidance rests on their shoulders, find protection with them.

78 Then shall all kinds of precious things be poured forth onto the laps of the clan members, numerous as bamboo culms, as men scatter rice, shall all sorts of possessions be spread on the splendidly crossed legs of the ones whose group always increases, as men cast seed.

79 Because thou art merciful gods, thou art lords great of compassion.

80 Let me now awaken thy co-gods here below, in the clefts of the earth, let me now arouse the ones who, with thee, are revered as lords, here below, in the dephts of the layers of the earth lying on each other.

81 Gods here below, upon whom the houses are built, upon whom the poles, that are cut to the correct size are erected, lords over whose heads it is fitting to walk.

82 Gods who carry [the earth] on the flat of the hands, who hold under us thy outstretched fingers as a floor.

83 The six supporting gods, the eight propping up gods.

84 God who balanced the period of the night and the day against each other, there below,

lord who determined the mutual relation of the dark and the light time. 
85 Deata umpatußara padaß, puan umballa' rante kalua'.

86 Deata ußgaraga uma ma'kambuno lumu', puaß urrante panompok ma'ta'duß doke-doke.

87 Deata umpakalolo tetean tampo, unna'ta' pananda uai, deata untanan pesunan banne sirenden.

88 Deata lumumban lani' rokko, puan sumoßko' to palullußan.

89 Deata tumari' allo dion, puan lumepon bulan.

90 Deata tumampa tau, kumombon to sanda raßka'na.

91 Deata tumampa to ma'puduk mundan, kumombon to ma'illon karumisik.

92 Tumampa pare tallu bulinna, kumombon ke'te' tallu eterna.

93 Deata unnambo' bintoen tasak, ussearan asi-asi.

94 Deata rume'pe' Bura', puaß ußkalumpena Sadaß.

95 Deata undandan Lemba, umbato' Tallu Situru'.

96 Deata tumoke' manukna Lapandek, unnaninni londonna Poß Tulaßdidi'.

97 Deata mamase, puan sa'pala buda.

98 Deata sampapa'na rokko, puan duan papa'na.

99 Deata tallunna papa'na rokko, a'pa'na, limanna papa'na rokko, puaß annanna papa'na, pitunna, karuanna papa'na rokko.

100 Deata kaseranna papa'na rokko, ganna' sampulo duanna.

101 Taß dilambi'na, ma'lolok didinna rokko, ma'tampak tambulinna. 
85 God who laid out the ricefields, lord who spread out the broad plain.

86 God who formed the wet ricefields, with duckweed as a sunshade, lord who created the dyked sawahs, like a plain, with a parasol of water plants.

87 God who stretched out straight the line of dykes of the ricefields, who extended the dams of the sawahs that keep the streaming water in bounds.

88 God who arched the firmament downwards, lord who curved the all-enfolding as the covering roof.

89 God who fashioned the sun, here below, as a disc, lord who cut out the moon as a circle.

90 God who created mankind, lord who formed the ones whose limbs are complete.

91 God who fashioned the one with lips like those of the wild duck, who created the one whose nose is like that of a small wild duck.

92 God who formed the three-eared rice, who shaped the cut one, branched in three.

93 God who scattered the yellow-shining stars, lord who spread abroad the lights of the night.

94 God who made the Pleiades to stand close together, lord who fashioned the curve of the constellation shaped like a mouth.

95 God who set the stars of the Great Bear in a row, who placed in a line the three that follow each other.

96 God who hung up the Fowl of Lapandek, who let the wind to blow over the Cock of Pon Tulandidi.

97 Merciful gods, lords great of compassion.

98 God of the first layer thereof downwards, lord of the second layer thereof.

99 God of the third layer thereof downwards, of the fourth, of the fifth layer thereof downwards, lord of the sixth layer thereof, the seventh, the eighth layer thereof downwards,

100 God of the ninth layer thereof downwards, of the twelfth, in completeness.

101 They are unreachable, they have a summit like that of the ribs of the leaves of the sugar palm beneath, they have a point like the tip of a lance. 
102 Iamo puan untulak padan, puaß parande padudur.

103 Deata sanda karua dioß, puaß ganna' bilazanna.

104 Deata sanda karua lo'na lu, puaß ganna' bilaßanna.

105 Deata sanda karua lan rampe matallona, puaß ganna' bilaßanna.

106 Deata sanda karua daanna lu, puaß ganna' bilaßanna.

107 Deata sanda karua lan una'na padaß, puaß ganna' bilaßanna.

108 Silelekomi kupalilin kanan, upu'mokomi kukambio santuß.

109 Silelemokomi kutamben bala tedon, upu'mokomi kuko'bi' riti bulaan.

110 Garagamokomi sanda silili', tampamokomi sanda sigontin..$^{\mathfrak{l}}$ )

114 Pokinallokomi to sanda ranka'na, pobokoß dilambanankomi to pantan tarunona.

115 Pokinallokomi to ma'puduk mundan, pobokon dilambanaßkomi to ma'illon karumisik.g)

122 Mintu' to dipoinaa, makalima'na to dipoba'ter. ${ }^{\mathrm{h}}$ )

128 Iamo padaß tiampa' seleß, iamo tana tiampallen doti lani'.

129 Ammi torro bulaan dao sendanan sugi' sitammu saßjdeatammi ma'pazan-pazan, ammi unnesuß batan-batan dao kaju mentaßke ianan ma'damerakmerak sirompa' sankapuaßammi, ammi metaa mammi', melale' sanda marasa.

130 Anku tundanopa saßdeatammi lan kapadaßanna, aßku rujaßopa saßkapuanammi lan kapajan-pajananna.

f) Strophes 111-113 are identical with 100-102 of B, and are therefore not included.

g) Strophes 116-121 are identical with strophes 106, 107, 109, 112, 113 and 114 of $\mathrm{B}$, and are therefore not included.

h) Strophes 123-127 are similar to strophes 194-198 of B, and are therefore not included. 
$102 \mathrm{He}$ is the lord who supports the earth, the lord who holds on his hand and bears on his head.

103 Thou gods, all eight of thee, below, lords, complete in number.

104 Thou gods, all eight of thee, in the South, lords, complete in number.

105 Gods, all eight of thee, in the East, lords, complete in number.

106 Gods, all eight of thee, over there in the North, lords, complete in number.

107 Gods, all eight of thee, in the innermost part of the earth, lords, complete in number.

108 Round thee now have I gone from the right, fingering the strumming instrument, and have summoned thee from first to last.

109 Round thee have I gone, from low unto high,

I have called thee, plucking the golden strings, from the beginning to the end.

110 Arrange a complete start consisting of all of thee, form a united departure in which all are included.

114 As sustenance for the journey, take the one whose limbs are complete, as provisions on the way, take the one whose members are entire.

115 As sustenance for the journey, take the one with lips like those of a wild duck,

as provisions on the way, take the one whose nose is like that of a small wild duck.

122 Everything that people have in their thoughts, all the things of which people are mindful.

128 It is the ground, spread out like an old woven cloth with a selen motif, it is the soil laid out like an old short wide fabric with a cross motif on it.

129 Then shalt thou, glittering like gold, remain on the richly laden tjendana tree and there meet thy co-gods, while chewing the betel quid, then, shining like tiny gold beads, shalt thou sit on the tree whose branches are full of precious things, together with the ones who, with thee, are revered as lords, while making thy mouths red, and laugh in a friendly manner, smiling sweetly.

130 Let me now awaken thy co-gods on the earth, let me now arouse the ones who, with thee, are revered as lords, in the open fields. 
131 Deata kambi'na te padaß tuo balo', puaß taranakna te tana tumbo kulau'.

132 Iamo deata kisano'koran, iamo puaß kisanesuran.

133 Iamo deata ußkambi'kan keallo keboni, iamo puaß ullaaikan te kulla' ke marassan.

134 Iamo deata kitimba bubunna, iamo puaß kiala tondon turunanna.

135 Iamo deata kilellen kajunna, deata kikalette' utan maluanna. ${ }^{1}$ )

176 Silelemokomi kupalilin kanan kukambio santun, upu'mokomi kutamben bala tedon kuko'bi' riti bulaan.

177 Da ammi luminka to belaß, da ammi ke'de' to bantala-tala.

178 Lendu'komi kali roßko' Duabontik ilan diDuri, su'bakki batu lappa'na Tallutoponna ilan diMalua'.

179 Lendu'komi ala roßko'na pekapuanan ilan diSaßalla', su'bakki batu lappa'na ma'dika matasak ilan diMa'kale.

180 Miala roßko'na Tutu'baka lan diBuntao', Mikala'pa batu lappa'na Kajok lan diUmakalua'.

181 Miala roßko'na Matabulaan ilan diKondozan, miala roßko'na Bakasiroe' ilan diMadandan.

182 Miala roßko'na Tannuntaßmanka ilan diNonozan.

183 Mipasituru'i takinan pia, selleran loton ulu, ma'bala tedoß, ma'paßkuß karambau.

184 Mipasituru'i bai makianakan, raßka' dipeaßla'i.

i) The place names in the strophes $136-175$ all occur in strophes 206-282 of B. There are a number of regions mentioned in B and whose gods are summoned but which do not occur here.

This offering prayer, G, contains the names of some regions which do not occur in B, namely, Saruran, Manßa', Tallulolo, Gandan Tuan, To' Sendana, Lebannu', Sangalani', Mamasa and Raya.

Saruran = water conduit, is an area near the village of Tona in the Kesu' territory; Manna' is a village lying to the north of the Ma'kale territory; Tallulolo: the three drains issuing from different points of a ricefield, is the name for a group of villages, Tadozkon, Sazbua' and Anin-anin, which form a 
131 Thou gods who guard this blessed region, lords who watch over this blissful land.

132 Those are the gods among whom we sit down together, they are the lords with whom we take our places.

133 Those are the gods who guard us by day and by night, they are the lords who watch over us during this day that shines on us.

134 Those are the gods from whose wells we scoop, they are the lords from the rim of whose well head we fetch water.

135 Those are the gods whose timber we cut down, the lords whose lush verdure we pluck.

176 Round thee now have I gone from the right, like someone fingering the strumming instrument, summoning thee, from low unto high have I called thee, as though plucking the golden strings, from the first to the last.

177 Thou shalt not go empty-handed, thou shalt not be without anything.

178 Call to Duri and dig up the good fortune of the Duabontik, unearth the prosperity of the Tallutoponna in Malua'.

179 Call to Sanalla' and fetch the good fortune of the ones called puan, dig up the prosperity of the noblemen of pure blood in Ma'kale.

180 Bring the good fortune of the Tutu'baka in Buntao', take hold of the prosperity of the Kayok in Umakalua'.

181 Bring the good fortune of the Matabulaan in Kondonan, fetch the prosperity of the Bakasiro-e in Madandan.

182 Bring the good fortune of the Tannuntaymanka in Nononan.

183 Provide that it results in the carrying of offspring on the hip, the bearing of a human being at the waist, the stalling of the buffalo, the stabling of the kerbau.

184 Provide that it results in the sows farrowing plentifully, and the toes that men always examine.

unit; Gandar is a village lying against the declivity of the Sarira Rocks in the Kesu' territory; Tuan and To' Sendana are hamlets of the village of Tadonkon in the Kesu' territory; Lebannu' is a hamlet of the village of Tona in the Kesu' territory; Sangalani' lies in the Tondon territory, to the east of the capital, Rantepao; Mamasa is the name of the territories lying on the Mamasa and Masuppu' Rivers, in the former division of Upper Binuan; Raya is an area in the Kanna group, an adat community consisting of 15 tonkonan = clan-houses, under the guidance of an adat chief called semban kada, the one who speaks the decisive words; this group lies in the mountainous regions, inhabited by the Toradja, of the upper basin of the River Djennemaedja in the Palopo division. 
185 Mipasituru'i pare tallu bulinna, sarita to lamban, maa' to unnoroß.

186 Mipasituru'i gajaß ditarapani, kandaure salombe', doti lani' tuo balo', maa' taß mate lu'pi'na.

187 Ammi mendaun sugi', mentanke ianan, mintu' to dipoinaa, makalima'na to la dipoba'ten.

188 Anna rampo lembaß inde tarampak banuanna to ma'rapu tallaß, iamo padaß tiampa' selez,

anna tu'tun koli-koli inde paßrampa' bulaanna to ma'kaponan ao', iamo tana tiampallen doti lani'.

H. KADA DIPAUPU', KE UMPATORROI PADAN SUSITE:

1 Ammi torro bulaan dao sendana sugi' ma'paßan-paßan titanan tallu: Puaß Matua, Poß Tulakpadaß na deata lan kapadananna!

2 Unnisuß batan-batanmokomi dao kaju mentaßke ianan ma'damerakmerak samba' batu lalikan, sitammu sazdeatammi, sirompa saßkapuaßammi. 
185 Provide that it results in the three-eared rice,

the old long narrow blue woven cloth with the design of men fording a river,

the old short wide fabric with the ones who are swimming.

186 Provide that it results in the gold kris of great size, the piece of beadwork with the cords hanging low, the old short wide woven cloth with a cross motif on it, which has a blessed length of life, the old short wide fabric, to whose folding-up there is no end.

187 So that thou mayest possess wealth in quantity, like the leaves, mayest have precious things, numerous as the branches of the tree, everything that people have in their thoughts, all the things of which people are mindful.

188 So that they arrive here, at the forecourt of the house of the clan members, numerous as bamboo culms, like the coming of a prau; that is the ground that lies stretched out, like an old woven cloth with a selen motif,

in order that they come to the golden court of the ones whose group always increases like a bamboo stool, like a small boat bumping [against the landing stage]; that is the soil which lies spread out, like an old short wide woven cloth with a cross motif on it.

H. THE CONGLUDING WORDS SPOKEN WHEN THE OFFERING OF SIRIH PINANG IS LAID DOWN

1 Mayest thou, thou trinity, in golden magnificence, remain on the richly laden tjendana tree, while chewing the betel quid, Puan Matua, Pon Tulakpadan, God of the Earth!

2 Then, shining like tiny small gold beads, shalt thou, the three belonging together, like the stones of the hearth, sit on the tree whose branches are full of precious things, in a meeting with thy co-gods, in a gathering with the ones who, with thee, are revered as lords, whilst making thy mouths red. 


\section{KADA DIPAUPU', KE UMPATORROI PESUY}

1 Ammi torro bulaan dao surasan tallaß, ammi unnesuß batan-batan dao ra'buß diaßgilo.

2 Sirondon karidisan panduß balo, sitammu sazdeatammi, sirompa' saßkapuazammi.

3 Mimembano sarinna kanan, mima'kaseroan bu'tu kalimbuaß, uai taß dilamban, sa'dan taß disarengai.

4 Kamupi unnola bonii, kamupi sarese dannarii, nadilamban, nadisarezgai.

5 La kumandemokomi sanda mammi' titanan tallu, la tumimbu'mokomi sanda marasa samba' batu lalikan.

6 Mintu'na deata ilani' makalima'na puan to palullußan, mintu' deata to keßkok, makalima'na puaß to kebali'bi', mintu' deata nasambo lani', makalima'na puaß narande tana kalua'.

7 Mikande bai taß sala' sampan, taß sala' kiki'.

8 Miiru' tuak taß lelaßan, taß panikian.

9 Taß disari boni, taß diambe malillin.

10 Pamba'ta to melo aluk, passari to melo bisara.

$3 a^{\prime} d a n$ in the poetical language means water. In the western territories of the Tana Toradja country, $s a^{\prime} d a n=$ great river. The large river in the country of the South Toradja is called the Sa'dan, and the people of the Tana Toradja, the Ma'kale and the Rantepao countries are often called Sa'dan Toradja.

5 The trinity, the ones who are three belonging together, are; Puan Matua, God of the Upper World; Pon Tulakpadan, God of the Underworld; and the God Who Lives on the Earth.

6 The gods who are covered by the firmament and whom the earth carries on her hands, are the gods of the earth.

8 lelaßan: occupied by a brown lizard; these often crawl into the palm wine containers.

panikian: occupied by a large bat. 
I. THE CONCLUDING WORDS WHEN THE LEAVES WITH THE OFFERING MEAL ON THEM ARE LAID DOWN

1 Shalt thou, in golden magnificence, remain on the small offering table, shalt thou, shining like fine gold beads, sit on the bamboo structure adorned with incised lines.

2 Near the place of the twisted leaf ribs of the sugar palm, wrapped round with kapok, smeared with the blood of the offering animals, at a meeting with thy co-gods,

in a gathering with the ones who, with thee, are revered as lords.

3 Shalt thou now wash thy hands in the cream of the water of the bluish ground,

shalt thou cleanse thy hands in that which springs forth from the well, water in which no one has trodden, the flowing one in which no person has set his foot.

4 Shalt thou now tread there in the night, shalt thou now place thy feet therein, before the dawn of the day, then shall it be trodden in, then shall it be water in which a foot has been set.

5 Shalt thou, thou trinity, now eat of the most delicious foods, shalt thou, the ones who are three, who belong together like the stones of the hearth, now partake of the most delightful dishes.

6 Thou gods of the firmament, all of thee, all the lords of the all-enfolding, complete, all thou gods of the underworld, thou lords of the ones who have fins, complete, all thou gods who are covered by the firmament, thou lords who are borne by the earth on her hands, complete.

7 Shalt thou eat the pig that is cut in pieces, without fault, which is divided into small portions, without error.

8 Shalt thou now drink the palm wine, in which no brown tree lizard is to be found, which no great bat has drunk.

9 Where no one has stolen any of it by night, where nobody has touched it at all in the darkness.

10 Which is tapped by someone who follows the correct rites, that is taken by somebody who has regard for the right adat performances. 
11 Lindo masakke randan to mamma', rupa madadindin irin to matindo, ra'pak-ra'pak puaß, passakke deata.

12 Nasusi Duabontik te randan pudukku, napopekadan roßko' te to ma'rapu tallaß, naten Tallutoponna te dara' lezko lilaku, napopetamba ianan te to ma'kaponan ao'.

13 Nasakendek-kendekna mendaun sugi', salaßßan-laßzanna mentaßke ianan, naala tonlona sugi', ma'lolosunns ianan.

11 "the first in the row of the sleeping ones", and "the foremost of the slumbering ones", are the sleeping gods.

12 "be as the Duabontik", and "be as the Tallutoponna", the magically powerful swords, means to be full of magical force.

\section{J. MA'TAMBULI}

1 Tamban manii bulu saß̧lamba'mu, te padaß tuo balo', la kutambuli bajak, tike'ken manii a'do sariummu, te tana tumbo kulau', la kusu'bak pekali bassi.

2 Tempon dinene'mu, tempon dinene'ki mudisu'bak pekali bassi, ke bendanni bozana gau', turan to dolomu mudilenta' kabombonan rara', ke tunannani samara bisara.

3 Kurre sumaßa'!

kurre sumana'!

kurre sumana'na!

$1 a^{\prime} d o$ : small hairs of the rice ear.

ma'tambuli $=$ to dig a hole in the ground with a pointed object.

$u s s u^{\prime} b a k=$ to pick at something, to dig at something.

2 bendan and tunannam $=$ to stand on end, to stand upright. 
11 May there be a benevolent countenance on the first in the row of the sleeping ones,

may there be a beneficial appearance from the foremost of the slumbering ones.

12 May the tips of my lips be as the Duabontik, which the clan members, numerous as bamboo culms, may use as a hook, in order to acquire prosperity,

may the words that flow from my lips, in their regular order, be as the Tallutoponna, which the group that always increases like a bamboo stool, may employ as a means of summoning precious things.

13 So that they may continually increase in wealth, in quantity like the leaves,

in order that the branching of the precious things may continue to swell still more,

so that they may reach the pinnacle of wealth,

in their possessions, achieving the absolute peak.

\section{J. THE INVOCATION AT THE MA'TAMBULI $=$ TO DIG A HOLE IN THE GROUND WITH A POINTED OBJECT}

This text is recited at the ma'tambuli rite. The to minaa makes a hole in the ground near the tjendana tree to which the buffalo that is to be slaughtered, is tied. Before doing this, the to minaa speaks the following, holding a digging stick in his right hand:

1 It may be that one of thy hairs will be frightened, $\mathrm{O}$ soil rich with blessings, where I shall stick the iron into it,

perhaps a thousand of thy small fibres will be alarmed, $O$ propseritybringing ground, where I shall make a hole with the iron digging stick.

2 From the time of thy ancestors, from the time of our forefathers, a hole is made in thee with an iron digging stick, when the feast of feasts is to take place,

from the time when one generation of thy ancestors followed each other, a small splendid shovel is stuck in thee, when the most illustrious of the rites is about to be performed.

3 Hail!

Hail!

Hail to thee! 
4 Kurre sumana'na te padaß tuo balo'! Iamo padaß seleß, saba' parajana te tana tumbo kulau'! Iamo tana tiampallen doti lani'.

5 Maßkamo napepali' manuk nene' mendeatanna te to ma'rapu tallaß nabazunni banua, upu'mo napebatu lappa' tanda sauzan to dolo kapuananna te to ma'kaponan ao' napatedekki a'riri sanda pati'na. ${ }^{a}$ )

8 Kurre sumaza'na te uaß mabilaßan, saba' parajana te panampa to Bone.

9 Kurre sumaza'na te ianan sanda rupanna, saba' parajana te baraß apa mintu' sola nasaß. ${ }^{\text {b) }}$ )

16 Kurre sumaza'na te pusuk lolon dilani', saba' parajana te daun induk turun dibintoen..$^{\mathbf{c}}$ )

20 Kurre sumaza'na te to matutu, saba' parajana te to mapato inaa..$^{\text {) }}$

22 Kurre sumaza'na te manuk sampe membuja, saba' parajana te kanuku diarru'.e)

24 Kurre sumaßa'na uma ma'kambuno lumu', saba' parajana panompok ma'ta'duß doke-doke.

25 Kurre sumaza'na pare tallu bulinna. saba' parajana ke'te' tallu etenna.

26 Kurre sumaßa'na patuku ma'dandan, saba' parajana te lampo' sielonan.

27 Kurre sumana'na te alaß disura' maa', saba' parajana te landa' dilekko busirrin.

a) Strophes 6 and 7 are identical with strophes 6 and 4 of B, and are therefore not included.

b) Strophes 10,11,12,13,14 and 15 are identical with strophes 10, 8, 7, 15, 16 and 17 of $\mathrm{B}$, and are therefore not included.

c) Strophes 17-19 are identical with strophes 12-14 of $\mathrm{B}$, and are therefore not included.

d) Strophe 21 is the same as strophe 19 of $\mathrm{B}$, and is therefore not included.

e) Strophe 23 is the same as strophe 18 of B, and is therefore not included.

5 pali' manuk = long unbroken scale of a fowl; the derived verbal form is napepali' manuk = they observe the long unbroken scale of the fowl, i.e. as a sign. The form napebatu lappa' is derived in the same manner.

20 In strophe 21 of $B$ there is a variation in the South Toradja text; the a line reads: Kurre sumana'na kaunan matutu, "Hail to the dutiful slaves", the b line reads: saba' parajana ruranan papatu inaa, "abundant be the blessing upon the obedient members of the house." 
4 Hail to this soil, rich with blessings! It is soil spread out like an old woven cloth with selen motifs,

abundant be the blessings upon this prosperity-bringing ground! It is stretched out like an old short wide fabric with cross motifs on it.

5 After the divine ancestors of these clan members, numerous as bamboo culms, had marked the long unbroken scale of the fowl, they built the house,

when the forefathers, revered as lords, of these members, whose group always increases like a bamboo stool, had noted the scale of the fighting cock, they erected the poles, cut to the correct size.

8 Hail to the vast quantity of old money, abundant be the blessing upon that shaped by the people of Bone.

9 Hail to these precious things of all kinds, abundant be the blessing upon all the possessions together.

16 Hail to these unfolded young leaves of the sugar palm, which have descended from heaven,

abundant be the blessing upon this foliage of the sugar palm, which has come down from the stars.

20 Hail to this dutiful one, abundant be the blessing upon this obedient one.

22 Hail to these fowls here, who thrive on the perch, abundant be the blessing upon the ones whose claws are trimmed with a small knife.

24 Hail to the wet ricefields, with duckweed as a sunshade, abundant be the blessing upon the dyked sawah which has a parasol of water plants.

25 Hail to the three-eared rice, abundant be the blessing upon the cut one, branched in three.

26 Hail to the stacked bunches of rice, placed in rows, abundant be the blessing upon these heaps of rice, set up twisted and sloping to a point.

27 Hail to the rice granary, adorned with a carved design, like that on old short wide woven cloths,

abundant be the blessing upon the storehouse of the rice, ornamented with an undulating pattern, like that on a fabric with the ant motif.

26 lampo': large cone-shaped sack made of the leaf sheath of the sugar palm, covered with a banana leaf, in which rice is cooked. These sacks are heaped up at the offering place when the offering is made at the beginning of the rice harvest, the menammu pare $=$ the greeting of the rice. 
28 Nanii urrinki' pare tallu bulinna simboloß manik, nanii unnala ke'te' tallu eterna lokkon loerara'. ${ }^{\prime}$ )

31 Kurre sumaßa'na te osokan ozan, saba' parajana te daun induk taß dipelolokki.

32 Kurre sumaßa'na te bane' sumomba matallo, saba' parajana te daun sumomba rekke.

33 Upu'mo te kukurre sumaßa', mintu' la napopake surasan tallaß, sundunmo te kupole paraja ronko'na karidisan panduß balo, nasielleran ra'buß diazgilo.

34 Denpa manii kusala kukurre sumaßa', denpa manii kulenda kupole paraja.

35 Limboßmo mendeatanna nene' maßanna saßka' inde rampe matampu', la umpasirundunan buloi, ke den kusala kukurre sumana', tasikmo menkapuazanna to ma'palumpun dibisara inde kabotoan kulla', la umpasitete malaa'i, ke denni kulenda kupole paraja.

36 Pakapaka to pada tindo, mintu' to sitinti panimpi.

37 Limbon dukamo Puaß Matua lan rampe matallo, tasikmo To Kaubanan lan kadellekan kulla', la umpasirundunan buloi, ke denni kusala kukurre sumaßa', la umpasitete malaa'i, ke denni kulenda kupole paraja.

f) Strophes 29 and 30 are the same as strophes 31 and 32 of B, and are therefore not included.

35 mendeat $=$ to turn and acquire a divine nature; this refers to the spirits of the ancestors who have become gods; the parallel term, menkapuanan $=$ the ones who have become lords, also means the spirits of the ancestors who have become gods. The spirits of these ancestors whose souls have ascended to the firmament, are also designated to membali puan = the ones who have become gods, lords. 
28 The knot of hair, shining like beads, will pick up from it the threeeared rice, little by little,

the roll of hair, hanging down like a golden neck ornament, will take from it the cut one, branched in three.

31 Hail to the sticking in the ground of the fronds for shade, abundant be the blessing upon the sugar palm with the leaves still on it.

32 Hail to these banana leaves which point respectfully towards the East, abundant be the blessing upon this foliage that bends in reverence to the North.

33 That is the completion of the things for which I invoke the blessing, everything used at the offering on the small offering table of bamboo struts on which a design is cut,

completed are the prayers that I speak for the successful wrapping round of the leaf of the sugar palm with blood-smeared kapok, which must be attached to the bamboo with incised lines.

34 Perchance I have missed out something in the spreaking of the invocation for blessing,

mayhap I have omitted something in the invoking of the benediction.

35 Come together now, here in the West, ancestors whose spirits became gods, the guardians of the Rules,

to put it in order in the proper manner, if there is something I have missed out in the speaking of the invocation for blessing,

gather in great numbers here, at the place where the shining one descends, thou whose spirits became lords, the ones who watch over the adat performances,

in order to arrange everything in the right way, if there is anything that I have omitted in the invoking of the benediction.

36 Thou, above all others, who hadst a dream of the same kind, all who dreamed with each other in concord.

37 Puan Matua, too, may then be together with them in the East, To Kaubanan, also, may then gather with a great multitude of them at the place where the shining one ascends,

to put it in order in the proper manner, if there is something I have missed out in the speaking of the invocation for blessing, in order to arrange everything in the right way, if there is anything that I have omitted in the invoking of the benediction. 
H. van der Veen - 978-90-04-28673-3

Downloaded from Brill.come4/26/2023 12:55:55AM 


\section{LIST OF SOUTH TORADJA WORDS}

which are mentioned in the notes attached to the strophes. 1

aluk $=$ religious prescriptions, offering ritual, 13 .

amburaß = spawn of a fish, 467.

ampo anak = grandchildren, children, 543.

anak dipayuni $=$ those over whom a sunshade is held, 480 .

anna popamuntu marendenna' Datu Laukk ' = then shall I be as a piece of durable, magical hard iron of a roasting dish for Datu Laukku', 503.

Arran Dibatu $=$ The Radiance in the Stone, 412.

Bakasiro-e: a pusaka-object, 298.

bane' sumomba matallo $=$ the banana leaves that are pointed respectfully towards the East, 573.

bangai $=$ tall, 325 .

ban $u^{\prime}=$ positively, 380 .

baolu $=$ bolu $=$ betel, 87 .

batakan = pole of a plough, 390 .

batan-batan = tiny round gold beads, 122.

bate lentekna $=$ his manner of going, 361.

batu ba'tan $=$ The stone of the innermost being, 359 .

batu lappa': the scale on the foot of a fighting cock, 292.

Batulobo' $=$ Stone that swells of its own accord, 296.

bayak: the part of the steel of a knife or a sword that is slightly whiter, 503.

binsu $=$ priestess, 755 .

bisara: adat performances, see aluk, 13.

boba $=$ large, stalwart, robust, 24 .

bonde = large testicles, 13.

bona: having white patches on the head, 6.

bulo $=$ thin bamboo, 622 .

bulo sanlampa $=$ straight internode of thin bamboo, 129.
Bun $a^{\prime}=$ First, Beginning, 63.

buntummi= thy mountain, 97.

bura $=$ foam, 607 .

burake: the priestess who officiates at the la'pa' feast, 655 .

daßkan = a span, 68; daßkanan $=$ measure of the size of a span, 68 .

darandan $=$ blood-smeared kapok, 337 .

Datu $=$ God, spirit, prince, 338 .

Datu Baine = Goddess, 338.

Datu Bakka': the ancestor of slaves, 676 .

Datu Laukku': the ancestress of mankind, 435.

Datu Menkamma': the ancestor of the leaders of the rice cultivation, 477.

Datu Muane = God, 341.

deata dibaßunni banua rokko $=\operatorname{god}$ upon whom the houses are built, 142 .

dialammi kalo' = a ditch was led away, 592.

dibatakanan $=$ ditenko $=$ it was ploughed up, 596.

dibato' batan-batan $=$ they were arranged like small gold beads, 433.

dieranni $=$ it was provided with a step, 87.

dionmi $=$ it was underneath, 508 .

dipalumokkon lalanna $=$ his path was folded, 462.

dipasilau' eran $=$ it is done from one step to the other, 622 .

dipasitanke pelalan $=$ it is held from one rung of the ladder to the other, 622.

dipotandi $k a l a^{\prime} k a^{\prime}=$ they were used as supports for the lower beams on which the floor rests, 472 .

diranduk = they were pricked into the ground, A4, C2.

donka: a kind of colacassia, 15.

dot $i$ lani $=$ the dots of the firmament, 10.

Duabontik: name of a fighting weapon

1 Only words that appear frequently in the strophes are given. The list is not compiled etymologically; the words are given in the form in which they occur in the notes.

The number of the strophe given is that in which the word or the term are first mentioned. Strophe numbers from all the texts A, C-J are preceded by the relevant letter. The B text, the Passomba tedon, strophe numbers have the number only. 
pointed at both ends, 292.

enkok = tail, 90 .

enkokna padan: the back part of the earth, 90.

eron $=$ wooden coffin, 84 .

gan maparek tannun $=$ as dense as woven cloth, 95.

gandaß $=$ drum, 662 .

garu'ga' = rocky hollow, 552.

$g a u^{\prime}=$ acts, procedure, offering procedure, rite, 6.

Gauntikemboß $=$ Self Expanding Cloud, 325.

Indo' Belo Tumbaß = Mother Ornament of People in a State of Trance, 728.

Indo' Buna Sampa = Benevolent Mother Blossom, 728.

indo' padan $=$ the leader of the rice cultivation and the offerings attendant thereon, 476.

Indo' Pare'-pare' $=$ Mother Small Kind of Rice, 347.

Indo' Sadenna $=$ Mother Everything Is in Hand, 348.

Indo'na ianan $=$ Mother of the Possessions, 111.

induk disila bannaß = sugar palm cleft along the prescribed line, A. 1.

kabarre-alloan = illumined by the shining disc of the sun, 293.

kalandona buntu $=$ the height of the mountain, 599.

Kambunolani' $=$ Sunshade of the Firmament, 533.

kamumo kupairin = I take thee as being the one on the extreme end of the row, 97.

kandaure $=$ piece of beadwork, 8 .

kanuku diarru': the claws which are trimmed with a small knife, 20.

$k a p a^{\prime} u r a n d e-r a n d e a n=$ the act of holding something on the flat of the hand, 48; the place where the gifts are offered on the flat of the hand, 650 .

kapayan-payananna $=$ visible, 332 .

kapuanan = having the status of a god or a lord; bearing the title of puan, 3 .

Karaen $M a^{\prime} l o k o-l o k o=$ Silent Lord, 477.

karambau = buffalo, 14 .

karaman pasiruanna $=$ the alluvial gravel of his spiritual state, 359 .

kararo $=$ coconut shell, 608 . karopok $=$ cranium, 92.

Kayok: name of a sword with magical power, 294.

kayu auk: a kind of tree, 32.

kayu todin $=$ speckled tree, 446.

kikalette' $=$ we cut off with the nail, 205.

kipoli'mora kaleki $=$ we shall brush ourselves out of the way, 603 .

kombon marapuan $=$ the extensive cultivation, 474.

kulla' = shining, glittering, 89 .

$k u m b a$ ': the pith of the main leaf rib of the high palm with a ringed horny trunk, 337.

kumila' = steep hanging wall of rock, 372.

kupa'kolakanni $=\mathrm{I}$ cast it before them, 39.

kupatinumbuko = I make thee push towards; I make thee touch, 718.

kurapakna tanke = the thick end of a branch where it joins the trunk, 458.

kurre; a word used to call the chickens, 1.

kutamben bala tedon = I stack up like the beams of the enclosure of the buffaloes' stall, 94 .

kutamben kalumbassi = I have laid thy ends across each other like the arcs of split bamboo, 98 .

lak $a=$ far, 383 .

lambe'na kombon kalua': the size of an extended plantation, 328 .

lando lalanni $=$ go on a journey in order to fetch, 383 .

lanzan: a kind of roasting spit, 635 .

Lapandek, a mythical person, 65.

lemba $=\mathrm{a}$ carrying pole, 64 .

lenko lila $=$ words spoken in regular order, 43.

le'to lolona $=\mathrm{a}$ part of their umbilical cord, 564 .

limbon $=$ pool; large fish pond, 38 .

lindo sara'ka': the front of the comb, 380.

lindomi sanda lindona $=$ the faces of all of them showed themselves, 586 .

lipu daenan $=$ dwelling area, 319 .

lisu aninan = centre part over which the wind blows, 758.

lokkon lo-erara': roll of hair, hanging down, like a golden chain, 30 . 
lola' = large armband, 111.

lonno': a kind of millet, 383 .

loton $u l u=$ the black-haired one, 4 .

lumbaa lani' = bamboo erected heavenward, 478.

maa': old woven cotton tjindai cloth, 10 . maa' tan mate lu'pi'na = cloth to whose

folding up there is no end, 454.

ma'burra $=$ spitting, 730 .

ma'damerak-merak=colouring the mouth red, 122.

maillin = moist, 563 .

mainnak = oil-bearing, 460 .

ma'kambelan = naked, 102.

ma'kambuno lumu' = having duckweed

as a sunshade, 23.

makatonan-tonan = actual, true 112 .

malaa' $=$ having long internodes, 40.

malimbo $=$ gathered together in a circle, 133.

maßaku $k u m b a^{\prime}=$ to confess guilt [with

a heart] weak as the kapok on the

rib of the leaf of the high palm

with a ringed horny trunk, 337 .

manapi'na tana $=$ the layers of the earth lying on each other, 141.

manore tanda darandan $=$ to cease to do wrong [with a heart] weak as the plug of blood-smeared kapok, 337.

manete: a form of tete $=$ bridge, 332 .

Manturini: the progenitor of the buffalo, 439.

manuk-manuk nakamalini $=$ they are perturbed because of the actions of the birds, 640 .

mapia = beautiful, C. 1 .

ma'ponka parompon $=$ to turn over the ground by digging, 43 .

ma'rebozan didi $=$ to count by breaking off pieces of the leaf ribs of the sugar palm, 738.

maro $=\operatorname{mad}, 439$.

masari dadik $=$ containing the fat of the milk, 35.

masirri = dreadful, frightful, 475 .

mata kalambanan: the right place to cross a river, 380 .

mata mabusa $=$ the white [of the] eye, 56.

mata maloton $=$ the black [of the] eye, 56.

Matabulaan $=$ sword with a gold blade, 297.

Verh. dl. 45 ma'tambuli $=$ to dig a hole in the ground with a pointed object, J. 1 .

matari' $=$ cut round; matari' allo $=$ cut round like the disc of the sun, 92 .

ma'tundu $=$ tiund $u=$ to nod assent, 378 .

mekutana london $=$ to call like a cock, A 2.

memparompon $=$ to sit with the lower part in the ground, 597.

menniso burinda: to bore like a grindstone, 373.

mentamben = to lay on's leg over someone, 446.

metinti masian $=$ constantly to give a clear call, A 2.

minana $=$ mouth of a river, 741 .

miseno ting $i=$ thou must shake it about as though it were dark red beads, 423.

nabalayanni $=$ he bound her with a liana, 444.

nakambio $=$ they flutter their finger tips and try to touch them, 79.

napabun $a^{\prime}=$ he causes himself to be the first, 207.

napaninoi anak dipayumi $=$ that with which the young people of high rank play, 480.

napoparamae $=$ with which they play, 473.

nasiria $=$ nasisaladan $=$ they hold each other on the lap, they cherish each other, 337.

nene' mendeata $=$ the forefathers who have the quality of gods, A 6 .

pa'barusan $=$ the parting in the middle of the hair, 143 .

$p a^{\prime} d u a n a n=$ that which is one of two associated objects, 10 .

paita $=$ seer, 585.

pakkan = the weft thread, 502 .

palempan: the conduit through which the water leaves the ricefield, 25.

pamuntu $=$ piece of wrought iron, 503.

pankalo puan $=$ the channels in the fields dug by the lords, 320 .

pananda $u a i=$ the regulator of the water, 608.

pandan $=$ determined by agreement, 92 .

paseko = sap wood of a tree, 67 .

pa'sullean allo $=$ the changing of the activities of the day, 338 .

patoko $=$ neck chain, 110 . 
patuma'bakan = structure of slats laid over the cross beams and on which the floor rests, 145.

pekapuazan $=$ he who is addressed as puan, 293.

pesun: the offering meal placed on a banana leaf, 385 .

pesuman banne $=$ the place on the ricefield where the offerings are laid for the new plantation, 50 .

pion $=$ rice or meat cooked in a bamboo container, 385.

pion sanlampa $=$ one internode full of cooked rice, 385.

Pon Bangairante $=$ Lord Whose Plain is Large, 325.

Pon Lalondon: the judge in the Land of The Souls, 346 .

Pon Malaleon: the ancestor of slaves, 683.

Pon Pirik-pirik $=$ Lord Small Windmill, 438.

Pon Tulakpadan $=$ Lord Who Supports the Earth, 142.

Pon Tulandenna $=$ Lord who Stays in a Definite Place, 344.

Pon Tulandidi', a mythical person, 65.

Potto Kalemban $=\mathrm{He}$ Whose Armband Is of Clay, 697.

puan $=$ God, Deity, Lord, 3 .

Puan Ambo-amboan = Lord Whose Skin Is Marked with Light Spots, B Introduction p. 13.

Puan Bassi-bassian = Lord Covered with the Spots of Old Age, B Introduction p. 13.

Puan Maro $=$ Lord Who Is Frenzied, 439.

Puaß Matua $=$ The Old Lord, 41.

Puan Raden $=$ Lord Who Leans Sitting Against Something, 342.

Puya $=$ Land of The Souls, 355 .

Pundusarai: small stone shaped like a buffalo", 295.

ra'bun = old bamboo shoots which are no longer eatable, 36 .

randan, edge, 97.

ra'tuk lani': white shining innerpart of a roasted rice grain of the firmament, which has split open, 788 .

rapa' = silent, satisfied, reconciled, A 3 . rara' $=$ neck chain, 2 .
Riako' also Datu Riako' = the progenitor of iron, 440.

rindin, = wall, 456.

rupa $=$ form, shape, colour, external appearance, 362 .

ruranan: a person, or a family, boarded in the house of another, 21.

sadan $=$ mouth, 63 .

salaga mennopan $=$ harrow that breaks things down, 449.

samara; completely black buffalo with a white patch on its head and a tail with a white tip, 6 .

sambo $r a^{\prime} t u k=$ covered with roasted rice grains, 655.

sampa': to recall in a ballad something that happened previously, 2 .

sanbua bannaß $=$ a single thread, 358 .

sandeatanna $=$ his co-god, 362 .

sandeatammi titanan tallu $=$ thy co-gods consisting of a group of three, 314 .

sankayu loli: a single piece of wood around which kapok or cotton has been wrapped, 358 .

sanserekan $=$ that which belongs to a part torn off the main body, 402 .

selle': to stick something between the waist and the clothing, 4 .

siayok $a=$ joined together by a yoke, 28. simbuan: that which is set up for purpose of tying up the buffaloes which are to be slaughtered at the death feast, 664 .

simbuan kalosi $=$ simbuan consisting of the trunk of an areca palm, 664 .

simbolon manik: knot of hair, shining like beads, 30 .

sipakuleasan $=$ to transport by swimming, 338.

sipogontinki $=$ those who regard our boundaries as theirs, 78 .

sipolili'k' $=$ those who regard our region as theirs, 77.

sirampanan kapa': to conclude an agreement to marry, 338 .

sissarean $=$ that which one leans against, 84.

sondon: in many regions of the Rantepao country it means a small room on the north side of the house, 758 .

sondon para: the three-cornered central upper part of the front and back walls of a house, 6 . 
sulin = flute, pipe, 125.

Sulo Taronko Malia' $=$ The Torch of the Hard Rock, 412.

sumallan $=$ the raised warp threads, 502. suman $a^{\prime}=$ consciousness, spirit, soul, 1. sumarre = luxuriant as sěrai grass, 498. sumonko' $=$ to make as a covering, 53. su'pimi = chip it; take it from it, 543. taban tua: old dragons' blood plant, 510 .

Ta'dun Kaissanan $=$ Renowned Hat, 533.

tagari: a kind of fragrant grass, 35 .

ta'gulinan = path on which one goes to and fro, 380 .

Takkebuku = Having No Kernel, 440.

takko: already robust and strong enough to perform all kinds of work, 323 .

tallan baine $=$ female bamboo, 384 .

tallan tan kelesoan $=$ thin bamboo culms without nodes, 129.

Tallo' Manka Kalena = Egg That Had Come Into Being of Itself, 338.

tallu bulinna $=$ that which has three ears, 22.

tallu etenna $=$ that which has three branches, 22.

Tallutoponna: name of a fighting weapon with three broad points, 292.

tambila: container for the small arrows of the blow pipe, 447.

tampa to Darru': the ironwork of the people of Darru', 480.

tananan samba': the erected poles; the poetical designation for the house, 10.

tanda tinaran $=$ like the small arrow of the blow pipe, 337.

Tandiminan $a=$ The Support of the River Mouth, 345.

tankean suru' $=$ the act of bringing an offering after confessing to a transgression, 380 .

tankena gaun = branch of a cloud, 458.

taßnsu' batakan $=$ to protrude like the pole of a plough, 390.

Tannuntanmank $a=$ The unfinished weaving, 299.

tarapan $=$ sarapan $=$ large gold kris, 8 .

tasak $=$ ripe, 62 .

tasik $=$ sea, 38 .

tasikmi batu rupanna $=$ together their faces were like the sea. 586 . te Indo' Simankoro $=$ this Mother Klewang, 9.

te tallu basonna $=$ that which is twisted into three ropes, 17.

te tonapa londonna $=$ this sword, its maleness, 9.

tedon = buffalo 14 .

tenko situru': the plough that goes in one and the same direction, A 3 .

tetanan $=$ the act of holding it on the hand, 380.

tetean tampo $=$ the act of going across the dyke of a ricefield, 470 .

tibua' tenko $=$ pushed as one would push a plough, 390 .

tille: a kind of reed with a soft inside, 544.

Timbayokila' $=$ Flashing Lightning, 343 .

tinke': round thin wooden splints on the spinning wheel, 656 .

tintian kala': the heddle to which the warp threads are attached, 95.

titanan tallu $=$ to be set (planted) as a trinity, A 6.

to ditanan indo' $=$ those who are planted as mothers, A4.

to gallay karauan $=$ he who wears an anklet of alloy, 568 .

To Kaubanan = The One Who Has Grey Hair, B Introduction p. 13.

to kebali'bi' = the ones with fins, 177.

to kenkok = the ones with tails, 177.

to makuyu lankan $=$ he who has the dishevelled feathers of a [sick] harrier, 479.

to malari $=$ those who sing and dance, another description of the to tumban, 758.

to maossa' manuk-manuk = he who has the ruffled feathers of a [sick] bird, 479.

to $\operatorname{mind} a-\operatorname{mind} a=$ any people whatsoever, 120.

to pada tindo $=$ those who had the same kind of dream, F 5 .

to palulluman $=$ that which envelopes, 53.

to paonanan $=$ that which shades, 45 .

to pekolon $k$ use $=$ those who carry on their backs a pouch made of the skin of a marsupial, 473.

to ponto litakan $=$ he who wears an armband of clay, 697 . 
to sanda ranka'na $=$ to ganna' tarunona $=$ the ones whose fingers are complete, 55.

to tumban: young girls and women who are in the state of taboo at the great la'pa' feast, 757.

tonkonan bara': the clan house which holds the most prominent position in the adat community, A 5 .

tumba': an honorific used before the names of the women who become to tumban, 511 .

turu-turu: a kind of centipede, 391.

Tutu'baka: name of a carrying basket with a lid on it, 294.

uainna Pon Pirik-pirik = the liquid of Pon Pirik-pirik, 554.

ullampak $=$ to cut off, 355 .

ullentenan panikuan: the turning over of the shuttle in the loom, 40 .

umballa' $=$ to unroll, 50 ,

umbille pantasi $=$ to separate one by one threads that have been soaked in rice water, A 6.

umparomponna $=$ its sitting with its root stock in the ground, 598. umparra uai mata budanna=he squeezed his many tears, 375 .

umpasikararoan = to weigh by using coconut shells as a measure, 49.

umpasirundunan bulo $i=$ to do as straight as an internode of thin bamboo, 40 . umpasitete $=$ to put in proper order, 40 . umpatale $=$ to distribute, 19.

umpatuzara $=$ to lay something on its back, 50 .

umpeotini $=$ to cut off, 355 .

$u n a^{\prime}=$ pith, marrow, soft heartwood, 428.

undedek $=$ to beat, to strike a drum, 400 . unkorok = to cackle, to crow, 10. unnarranni $=$ brooding over, 10 . unnosok $=$ to stick in a hole, 142. untakin = to bind something to the waist, 4.

untandin talina $=$ to hear, 372 .

urra'ta' kasembayanna = settling finally by means of a trial, 481 .

usserek bannan $=$ to draw apart one by one, A 6.

Usuk Sazbamban $=$ The One Special Rib, 366. 


\section{VERHANDELINGEN}

1. H. Terpstra, De Factorij der Oostindische Compagnie te Patani. 1938.

2. E. J. van den Berg, De val van Sora. 1939.

3. C. Nooteboom, Oost-Soemba. 1940.

4. M. A.P. Roelofsz, De vestiging der Nederlanders ter kuste Malabar. 1943.

5. Hadji Hasan Moestapa, Over de gewoonten en gebruiken der Soendanezen. 1946.

6. J. J. Dormeier, Banggaisch Adatrecht. 1947.

7. W. F. Stutterheim, De kraton van Majapahit. 1948.

8. F. S. Eringa, Loetoeng Kasaroeng. Een mythologisch verhaal uit West-Java (Eerste gedeelte). 1949.

9. A. Teeuw, Hariwańśa. 1950. 2 delen.

10. G. Maan, Proeve van een Bulische Spraakkunst. 1951.

11. J. C. Anceaux, The Wolio Language. Outline of Grammatical Description and Texts. 1952.

12. J. Wils, Het passieve werkwoord in de Indonesische talen. 1952.

13. H. J. de Graaf, De regering van Panembahan Sénapati Ingalaga. 1954. 
14. John Bastin, Raffles' ideas on the Land Rent System in Java and the work of the Mackenzie Land Tenure Commission. 1954.

15. Graham Irwin, Nineteenth-Century Borneo. A study in Diplomatic Rivalry. 1955.

16. C. Hooykaas, The Old-Javanese Rāmāyana Kakawin with special reference to the problem of interpolation in kakawins. 1955.

17. P. Donatus Dunselman O.F.M. Cap., Kana Sera. Zang der zwangerschap. 1955.

18. G. W. J. Drewes, Een 16de eeuwse Maleise vertaling van de Burda van Al-Būṣīī (Arabisch lofdicht op Mohammad). 1955.

19. W. Kern, Commentaar op de Salasilah van Koetai. 1956.

20. G. J. Held, Waropense teksten. 1956.

21. H. R. van Heekeren, The Stone Age of Indonesia. 1957.

22. H. R. van Heekeren, The Bronze-Iron Age of Indonesia. 1958.

23. H. J. de Graaf, De regering van Sultan Agung en die van zijn voorganger. 1958.

24. G. W. J. Drewes and P. Voorhoeve, Adat Atjèh. 1958.

25. A. Teeuw, Lombok. Een dialect-geografische studie. 1958.

26. Teuku Iskandar, De Hikajat Atjèh. 1958.

27. H. J. Marks, The first contest for Singapore 1819-1824. 1959.

28. J. Brugman, De betekenis van het Mohammedaanse recht in het hedendaagse Egypte. 1960.

29. E. M. Uhlenbeck, met medew. van J. Soegiarto, Aantekeningen bij Tjan Tjoe Siem's vertaling van de lakon Kurupati rabi. 1960.

30. E. M. Uhlenbeck, Het systeem der Javaanse pronomina. 1960.

31. Jan van Lohuizen, The Dutch East India Company and Mysore 1762-1790. 1961.

32. Han Bing Siong, An Outline of the recent History of Indonesian Criminal Law. 1961. 
33. H. J. de Graaf, De regering van Sunan Mangku-Rat I Tegal-Wangi, Vorst van Mataram, 1646-1677. I. De ontbinding van het rijk. 1961.

34. H. Myron Bromley. The Phonology of Lower Grand Valley Dani. 1961.

35. J. C. Anceaux, The linguistic situation in the Islands of Yapen, Kurudu, Nau and Miosnum, New Guinea. 1961.

36. G. W. J. Drewes, De Biografie van een Minangkabausen Peperhandelaar in de Lampongs. 1961.

37. J. P. K. van Eechoud, Etnografie van de Kaowerawédj (Centraal Nieuw-Guinea). 1962.

38. Tapan Raychaudhuri, Jan Company in Coromandel, 1605-1960. 1962.

39. H. J. de Graaf, De regering van Sunan Mangku-Rat I Tegal-Wangi, Vorst van Mataram, 1646-1677. II Opstanding en ondergang. 1962.

40. C. Skinner, Sja'ir Perang Mengkasar (The Rhymed Chronicle of the Macassar War) by Entji' Amin. 1963.

41. Silvia W. de Groot, Van isolatie naar integratie. De Surinaamse Marrons en hun afstammelingen. Officiële documenten betreffende de Djoeka's (1845-1863). 1963.

42. P. Drabbe, Drie Asmat-dialecten. 1963.

43. S. J. Esser, De Uma-taal (West Midden-Celebes). Spraakkunstige schets en teksten. 1964.

44. J. C. Anceaux, The Nimboran Language. Phonology and Morphology. 1965. 